Florida International University FIU Digital Commons

$11-6-2009$

\title{
Diversity of Hymenoptera, Cultivated Plants and Management Practices in Home Garden Agroecosystems, Kyrgyz Republic
}

Robin Currey

Florida International University, robin.currey@gmail.com

DOI: $10.25148 /$ etd.FI09120805

Follow this and additional works at: https://digitalcommons.fiu.edu/etd

\section{Recommended Citation}

Currey, Robin, "Diversity of Hymenoptera, Cultivated Plants and Management Practices in Home Garden Agroecosystems, Kyrgyz Republic" (2009). FIU Electronic Theses and Dissertations. 124.

https://digitalcommons.fiu.edu/etd/124 


\section{FLORIDA INTERNATIONAL UNIVERSITY \\ Miami, Florida}

DIVERSITY OF HYMENOPTERA, CULTIVATED PLANTS AND MANAGEMENT PRACTICES IN HOME GARDEN AGROECOSYSTEMS, KYRGYZ REPUBLIC

A dissertation submitted in partial fulfillment of the requirements for the degree of DOCTOR OF PHILOSOPHY

in

BIOLOGY

by

Robin Colleen Dougherty Currey 


\section{To: Dean Kenneth Furton}

College of Arts and Sciences

This dissertation, written by Robin Colleen Dougherty Currey, and entitled Diversity of Hymenoptera, Cultivated Plants and Management Practices in Home Garden Agroecosystems, Kyrgyz Republic, having been approved in respect to style and intellectual content, is referred to you for judgement.

We have read this dissertation and recommend that it be approved.

$\begin{array}{r}\hline \text { Bradley Bennett } \\ \hline \text { Suanadev Bhat } \\ \hline \text { William Vickers } \\ \hline \text { David Lee, Major Professor }\end{array}$

Date of Defense: November 6, 2009

The dissertation of Robin Colleen Dougherty Currey is approved.

Dean Kenneth Furton

College of Arts and Sciences

Dean George Walker

University Graduate School

Florida International University, 2009 
C Copyright 2009 by Robin Colleen Dougherty Currey

All rights reserved. 


\section{DEDICATION}

This research is dedicated to Kahina and Smail Bouferguene and my extended family in Tosor and Tamga, especially Daria Toguzbaeva. 


\section{ACKNOWLEDGMENTS}

I wish to thank the residents of Tosor and Tamga for sharing their gardens and their lives with me. Daria Toguzbaeva and her family's openness and friendship, especially Munara and Chinara, made this research possible and made me a better person. David Lee's, Suzanne Koptur's, William Vickers', Bradley Bennett's and Mahadev Bhat's guidance have been particularly helpful in crafting this research and this dissertation. I would like to especially acknowledge Dr. Lee and Dr. Koptur for introducing me to the wild world of pollination and gardening. Dr. Richard Ford's mentoring and confidence in me was the foundation for my professional development in the field of ethnoecology. Catherine Brown's support is acknowledged and appreciated. Research described herein approved under IRB approval 021603-00 from FIU.

I would like to thank Nurjan Eshimov for collecting and mounting specimens; Dmitry Milko for insect identification and helping me to learn about Kyrgyz entomofauna; Anna Ostashko for statistical consulting; Jacob Fleming for garden mapping and apricot and apple taste testing; Bakhtiyar Ergashev for teaching me how to work with communities; Nurgul Israilovna for her wild ideas and Aleksandr Kirillov for his realistic approach. A special thanks to Mercy Corps and Kompanion and our donors and investors for supporting new ways of working with rural residents and their gardens. The research described in this dissertation has been funded in part by the United States Environmental Protection Agency (EPA) under the Science to Achieve Results (STAR) Fellowship Program, Florida International University’s Presidential Enhanced Graduate Assistantship for Doctoral Studies, Fulbright's Graduate Research Fellowship, the National Geographic Society's Conservation Trust and Mercy Corps' Phoenix Fund. 


\begin{abstract}
OF THE DISSERTATION
DIVERSITY OF HYMENOPTERA, CULTIVATED PLANTS AND MANAGEMENT

PRACTICES IN HOME GARDEN AGROECOSYSTEMS, KYRGYZ REPUBLIC
\end{abstract}

\author{
by \\ Robin Colleen Dougherty Currey \\ Florida International University, 2009 \\ Miami, Florida \\ Professor David Lee, Major Professor
}

Pollination-dependent fruit trees grown in home gardens play an important role in the agricultural based economy of Central Asian countries, yet little is known about the status of pollinator communities, the cultivated plant composition or the factors that influence management practices in Kyrgyz home garden agroecosystems. As agricultural systems are human created and managed, a logical approach to their study blends anthropological and ecological methods, an ethnoecological approach. Over three years, I investigated how species richness and abundance of Hymenoptera, cultivated plants, and home garden management were related using quantitative and qualitative methods in the Issyk-kul Man and Biosphere reserve. Structured surveys were undertaken with heads of households using a random sample stratified by village. Gardens were then mapped with participation of household members to inventory edible species in gardens, most of which are pollinator-dependent, and to compare home garden diversity as reported by respondents during interviews. Apple diversity was studied to the variety level to understand respondents' classification system in the context of in situ agrobiodiversity conservation. Household members identified 52 edible plant species 
when mapping the garden, compared with 32 reported when interviewed. The proportion of plant species received from others through exchange and the number of plots cultivated significantly explained the variation in edible plant diversity among gardens. Insects were sampled in gardens and orchards to determine potential pollinator community composition and the effect of different management practices on Hymenoptera richness and abundance. I collected 756 Hymenoptera individuals ( 56 bee; 12 wasp species); 12 species were new records for Kyrgyzstan or within Kyrgyzstan. Economic pressures to intensify cultivation could impact management practices that currently promote diversity. A home garden development initiative was undertaken to study management practice improvement. Participants in the initiative had higher adoption rates than controls of management practices that improve long-term yield, ecological sustainability and stability of home gardens. Home gardens, as currently managed, support abundant and diverse pollinator communities and have high cultivated plant diversity with few differences in community composition between garden management types. 


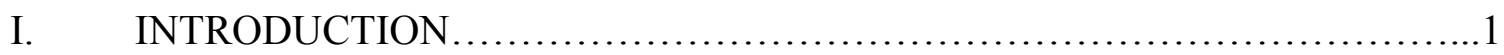

List of References .......................................................

II. HOME GARDENS AND AGROBIODIVERSITY: AN

ETHNOECOLOGICAL APPROACH .....................................16

List of References ......................................................

III. EDIBLE PLANT SPECIES DIVERSITY IN KYRGYZ HOME

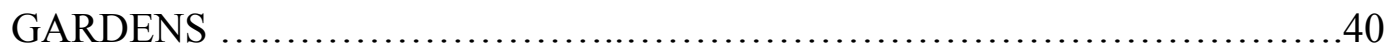

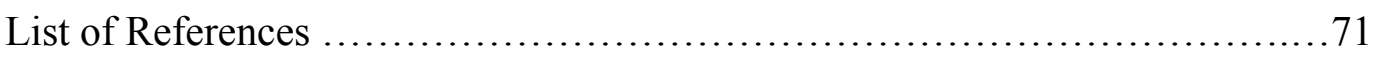

IV. HOME GARDENS CONSERVE HYMENOPTERA DURING APPLE

BLOOM, ISSYK-KUL, KYRGYZ REPUBLIC …........................ 82

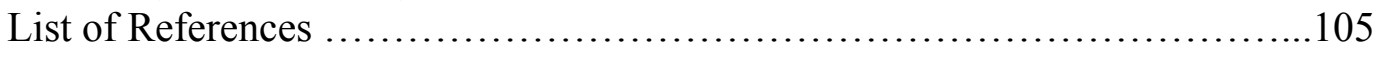

V. NEW HYMENOPTERA RECORDS FROM APPLE

AGROECOSYSTEMS, ISSYK-KUL BASIN, KYRGYZ REPUBLIC ..........120

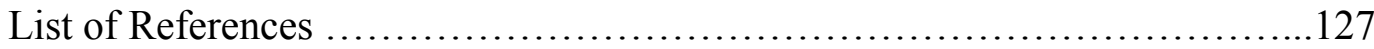

VI. HOME GARDEN DEVELOPMENT INITIATIVE IMPROVES

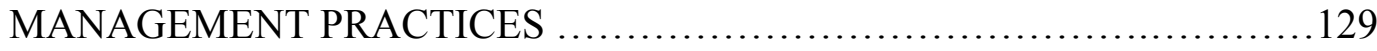

List of References ................................................... 162

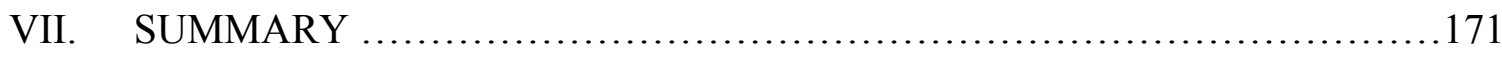

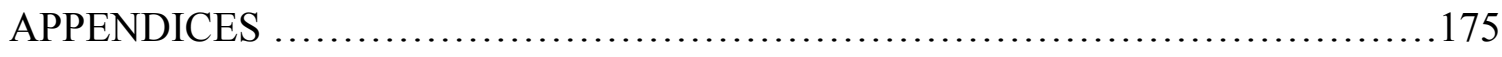

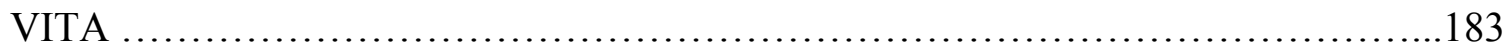




\section{LIST OF TABLES}

TABLE

PAGE

\section{CHAPTER III}

Table 1. Characteristics of households and household member who primarily tends the home garden in Tosor and Tamga, northeastern Kyrgyzstan $(\mathrm{N}=21)$ .76

Table 2. Characteristics of households interviewed in Tosor and Tamga, Kyrgyzstan $(\mathrm{N}=21)$ .77

Table 3. Livestock holdings of households, Tosor and Tamga, Kyrgyzstan $(\mathrm{N}=21)$

Table 4. Perceptions of environmental issues and management practices in home gardens, Tosor and Tamga, Kyrgyzstan: proportions of households (binary data)

Table 5. Edible plant diversity, yields, and sales as reported by households, and as mapped, in home gardens, Tosor and Tamga, Kyrgyzstan

Table 6. Sources of plant material for fruit and vegetable species in home gardens as reported by households, Tosor and Tamga, Kyrgyzstan

Table 7. Regression models of number of edible fruit species in home gardens as reported by households and as mapped in gardens $(\mathrm{N}=20) * * * \mathrm{p}<0.001$; ** $\mathrm{p}<0.01 ; * \mathrm{p}<0.05$

Table 8. Regression models of number of edible fruit species in home gardens as mapped in gardens with respect to environmental issues $(\mathrm{N}=19)$ $* * * \mathrm{p}<0.001 ; * * \mathrm{p}<0.01 ; * \mathrm{p}<0.05$

\section{CHAPTER IV}

Table 1. Characteristics of home gardens $(\mathrm{N}=8)$ and orchards $(\mathrm{N}=8)$ in two villages, Issyk-kul Region, Kyrgyzstan

Table 2. Results of stepwise multiple regression analyses for dependent variables and the independent variables of overstory cover, percent overstory in bloom, height of vegetation, and percent vegetative ground cover 


\section{CHAPTER VI}

Table 1. Characteristics of households in December 2008, both participants in agricultural development initiative $(\mathrm{N}=267)$ and non-participants $(\mathrm{N}=335)$, from eight villages, Issyk-kul region, northeastern Kyrgyzstan ...............166

Table 2. Characteristics of household income pre- (2007) and post- (2008) development initiative agricultural trainings for participants $(\mathrm{N}=267)$, from eight villages, northeastern Kyrgyzstan. \$1 USD $=37.75 \mathrm{KGS}$ in 2007; $\$ 1 \mathrm{USD}=36.11 \mathrm{KGS}$ in 2008

Table 3. Characteristics of household income pre- (2007) and post- (2008) development initiative agricultural trainings for non-participants $(\mathrm{N}=335)$, from eight villages, northeastern Kyrgyzstan. \$1 USD = 37.75 KGS in 2007; $\$ 1 \mathrm{USD}=36.11 \mathrm{KGS}$ in 2008

Table 4. Comparison of the proportions of households in the two groups, participants $(\mathrm{N}=267)$ and non-participants $(\mathrm{N}=335)$, using different management practices in 2007 (PR and NPR) and 2008 (PR and NPR). Two-sample tests for differences in means between groups ( $\mathrm{t}$-test and $\mathrm{z}$-tests for proportions); degrees of freedom $=600$ for all

Table 5. Adoption of home garden management practices by participants $(\mathrm{N}=267)$ and non-participants $(\mathrm{N}=335)$ following development initiative using McNemar's test for symmetry for comparing dependent proportions. Percentage of households that adopted practices and those that continued practices from 2007 to 2008 reported

Table 6. Simple linear regression models predicting square-root transformed home garden and apple sales income for participant and non-participant households, combined, following home garden development initiative targeting low external-input technology techniques by horticultural/ agricultural management practice 


\section{LIST OF FIGURES}

FIGURE

PAGE

\section{CHAPTER II}

Figure 1. The Landscape-Lifescape conceptual model for ethnoecological research (adapted from Nazarea 199:92) .

\section{CHAPTER VI}

Figure 1. Sample-based (Mao Tau) rarefaction curves with 95\% confidence intervals for Hymenoptera between (a) home gardens (squares) and orchards (triangles) in 2006; (b) locality, or village, (Tamga, squares; Tosor, triangles); and (c) years (2005, triangles; 2006, squares)

Figure 2. Results of simple linear regressions showing the relationship between (a) the number of Hymenopteran individuals $(\mathrm{F}=17.84, \mathrm{~N}=16, \mathrm{P}=0.001)$ and (b) the number of bee individuals $(\mathrm{F}=13.00, \mathrm{~N}=16, \mathrm{P}=0.003)$ and the height of ground cover vegetation

Figure 3. Results of simple linear regressions showing the relationship between (a) the number of solitary bee individuals $(\mathrm{F}=15.181, \mathrm{~N}=16, \mathrm{P}=0.002)$ and (b) the number of solitary bee species $(\mathrm{F}=5.256, \mathrm{~N}=16, \mathrm{P}=0.038)$ and the height of ground cover vegetation

Figure 4. Results of simple linear regressions showing the relationship between (a) the number of social bee species $(\mathrm{F}=6.91, \mathrm{~N}=16, \mathrm{P}=0.020)$ and $(\mathrm{b})$ the number of bumble bee species $(\mathrm{F}=6.91, \mathrm{~N}=16, \mathrm{P}=0.020)$ and the percent vegetative ground cover (logit transformed)

Figure 5. Results of simple linear regressions showing the relationship between (a) the number of wasp individuals $(\mathrm{F}=8.88, \mathrm{~N}=16, \mathrm{P}=0.020)$ and $(\mathrm{b})$ the number of wasp species $(\mathrm{F}=6.81, \mathrm{~N}=16, \mathrm{P}=0.021)$ and the percent vegetative ground cover (logit transformed)

Figure 6. Results of simple linear regression showing the relationship between the number of bumble bee individuals and the percent of overstory cover $(\mathrm{F}=$ $6.12, \mathrm{~N}=16, \mathrm{P}=0.027$ )

Figure 7. NMDS plots of species community composition between: (a) Hymenoptera species and locality (village); (b) solitary bees and agroecosystem type: home gardens and orchards; and (c) solitary bees and locality (villages Tosor and Tamga, $12 \mathrm{~km}$ apart) 


\section{CHAPTER I}

\section{INTRODUCTION}

Home Gardens and Biodiversity

Small farmers, home gardeners, produce the majority of food in the developing world (Hall 2001). Home gardens are small-scale agroforestry systems with a mixture of trees, shrubs, herbs and other cultivated crops located in the area surrounding a house, maintained and managed by those in the household (Fernandes and Nair 1986, AguilarStøen et al. 2009). The boundaries of home gardens can be diffuse or, as in the Former Soviet Union, well defined, delimited by fencing or walls. Home garden systems are fundamentally different from large scale agriculture: they use no chemical inputs, are not mechanized, and host high levels of diversity including agrobiodiversity, non-cultivated plant diversity, as well as insect, mollusk and bird diversity (e.g., Hylander and Nemomissa 2008, Raheem et al. 2008). Improving smallholder farming systems is critical for reducing hunger and poverty through long-term growth in agricultural productivity (Hall 2001). Mitigating negative environmental effects that often accompany agricultural growth, such as agrobiodiversity and biodiversity loss, deterioration of ecosystem services, and contamination is a critical challenge for conservation science (Norris 2008).

Biodiversity loss directly and negatively impacts human populations because of the fact that we depend on the natural environment for food, medicines, raw materials and other 
resources such as water (Primack 1998). The effects of loss are cascading- that is, many independent factors collectively exacerbate biodiversity loss to a greater degree than each individual threat (Primack 1998). Home gardens have been identified as playing a critical role in the preservation of genetic variability for many agricultural species, which constitutes the foundation of future food availability (Ford 1994).

Biodiversity refers to the number of species in a given area, the genetic diversity of those species and also the diversity of life forms, and it plays a role in stabilizing community and ecosystem processes (Tilman 1996, Primack 1998). Applying biodiversity concepts in human-occupied space to issues of resource sustainability is challenging because of the mixture of both ecological and human components (Soberón et al. 2000). Nonetheless, home gardens play two major roles in the conservation of biodiversity at two different scales: within the garden and the garden itself. There can be many different species and varieties of plants within gardens (e.g., Nabhan 1985) while the gardens themselves can serve as habitat for other plant, insect and animal species that are not intentionally planted or tended by households (e.g., Perfecto et al. 1996, Hylander and Nemomissa 2008, Raheem et al. 2008).

Home gardens, low-intensity agro-forestry plots, and abandoned temperate orchard meadows all tend to have high levels of biodiversity, and are known to be important for the conservation of not only agrobiodiversity (Altieri 2004), but also birds (Mas and Dietsch 2004, Perfecto et al. 2005, Dietsch et al. 2007) and insects (Klein et al. 2003, Perfecto et al. 2003, Steffan-Dewenter 2003, Steffan-Dewenter and Leschke 2003, 
Armbrecht et al. 2005, Gardener and Ascher 2006, Winfree et al. 2008). The latter reported that orchard meadows in Central Europe are one of the most species rich habitat types and that bees and wasps are good indicator species. Bees are good indicators of floral diversity and wasps of insect and spider diversity (Kevan 1999, Steffan-Dewenter and Leschke 2003).

Insects, Income and Crops in Kyrgyz Home Gardens Home gardens in the Kyrgyz Republic contribute as much as $50 \%$ of agricultural value added and marketed surplus for the Kyrgyz Republic, and provide households, despite their small size (average $0.1 \mathrm{ha}$ ), with a sizable portion of their income (World Bank Kyrgyz Republic 2005). In 2006, fruit and berry production in Kyrgyzstan was over 186,600 tons, with nearly $62 \%$ of that yield being grown in home gardens (National Statistics Committee of the Kyrgyz Republic 2008). Apples from home gardens provided households in the Issyk-Kul region of Kyrgyzstan with nearly $10 \%$ of their annual revenue (Ostashko and Currey 2007). Earning income from the sale of home garden production is not a new trend, and this pattern of production is not unique among countries of the former Soviet Union (Seeth et al. 1998, Lerman and Stanchin 2004). For example, Seeth and co-authors (1998) found that $90 \%$ of fruit and berries in Russia were grown in home gardens and small private plots, and households in Turkmenistan earned $36 \%$ of their income from home gardens (Lerman and Stanshin 2004).

The dominant tree species in home gardens of northern Kyrgyzstan are apple (Malus X domestica Borkh.), apricot (Armeniaca vulgaris Lam.), pear (Pyrus communis L.); shrubs 
include currant (Ribes spp. L.) and raspberry (Rubus spp. L.), and a variety of vegetables, herbs, and grasses are present in home gardens. Apple cultivars are predominately selfsterile but can also be variably self-fertile or self-fertile (Pratt 1988). In general, apple flowers must be insect (or hand) pollinated to obtain fruits (McGregor 1976, Partap and Partap 2002). Pollinators of apple flowers are known to include honeybees, bumble bees, solitary bees and some flies (Scott-Dupree and Winston 1987, Kearns 2001, Partap and Partap 2002). In the Kyrgyz Republic, we lack published research on pollinator communities and insect communities in home garden systems (Chelpakova and Milko 2004). The lack of information on the entomofauna of Kyrgyzstan is an especially notable gap in knowledge, given the number of economically important, insect pollinatordependent agricultural species whose wild relatives are native to the region. Crop wild relatives in Kyrgyzstan include the main progenitor of cultivated apple, M. sieversii (Lebed.) M.Roem.; M. niedzwetzkyana Dieck., another wild relative of the domesticated apple; the wild apricot, Armeniaca vulgaris Lam., the wild pear Pyrus korshinskyi Litv., and the almonds, Amygdalus bucharica Korsh. and A. ledebouriana Schlecht., among others (Ministry of Environmental Protection 1998, Dzhangaliev et al. 2003, Forsline et al. 2003, Eastwood et al. 2009, IUCN 2009).

Wild pollinators are important for crop pollination, but habitat destruction and land use intensification, especially in agricultural landscapes, can threaten pollinator communities and their ability to provide crop pollination services (Steffan-Dewenter and Westphal 2008). Globally, wild pollinators are in decline for a number of reasons including habitat loss and fragmentation, pesticide use, and disease (Banaszak 1992, Buchmann and 
Nabhan 1996, Kearns and Inouye 1997, Kevan 1999, Kearns 2001, Goulson 2003, Billeter et al. 2008). However, Steffan-Dewenter and Westphal (2008) noted a gap in pollinator research from subtropical and temperate regions and contrasting results concerning the effects of different agricultural management strategies on pollinator communities and pollination services (Kevan 1999, Winfree et al. 2008). Contributions from Central Asia have been noticeably absent in recent research detecting pollinator declines and pollination limitation, even though the mountains of Central Asia are a global biodiversity hotspot (Davis et al. 1995). Very little is known about the ecology of agriculture in the Kyrgyz Republic and there is a paucity of information concerning insect community composition and agrobiodiversity in Kyrgyzstan, especially in home gardens (Chelpakova and Milko 2004).

Home gardens and other forms of agroecosystems are important to the conservation of plant resources when it is considered that "these plant resources are directly dependent upon management by human groups, thus, they have evolved in part under the influence of farming [land use] practices shaped by particular cultures" (Altieri et al. 1987: 49). Thus, diverse cultures in a region apply distinct folk-scientific and aesthetic criteria to the selection of plants (Nabhan 1985, Jain 2000). As agricultural systems, including home gardens, are human created and managed, a logical approach to their study blends anthropological and ecological points of view and methods: an ethnoecological approach.

Ethnoecology has been described as "a way of looking" at land, and the relationship humans have with the environment, that incorporates the role of cognition in shaping 
behavior and management (Nazarea 1999). It deals with human cognition of environmental components (e.g., plants, animals, water, soils) and the classification of its components within a given environment (Nazarea 1999). Ethnoecology grew somewhat in response to the discounting of traditional ecological knowledge and management practices employed by indigenous cultures as random, destructive and primitive (Nazarea 1999). Conklin (1954) introduced the notion of an "ethnoecological approach" and since that time ethnoecological investigations have sought to understand "local" perceptions and landuse practices (Nazarea 1999). Many ethnoecological studies are concerned with the management of natural resources (biotic and abiotic) and practitioners seek to make their research part of international efforts of biodiversity protection and the recognition of indigenous knowledge (Ford 1994).

With the proposition that home gardens and other agroforestry systems can serve as a reservoir for biodiversity, many non-governmental and governmental agencies are seeking ways to conserve existing agroecological systems. However, with increasing food insecurity, climate change, and calls for agricultural intensification, conserving existing agroecosystems, home gardens, and the diversity of plants and other organisms within them faces serious challenges (Lobell et al. 2008, Norris 2009). Across disciplines, there is consensus that food demand is increasing and that will put pressure on the ecological integrity of agricultural systems. Most small farmers, home gardeners, live in resource-poor areas in environments that are already ecologically vulnerable and more at-risk to ecological degradation (Altieri 2002, Lobell et al. 2008, Norris 2008). Employing a model for research that integrates ecological, sociological, economic and 
anthropological methods can help address why certain management practices are successful and why others fail to inform biodiversity conservation and efforts to preserve and improve agricultural livelihoods.

\section{Research Objectives}

The objectives of this dissertation research were:

1) to document the edible plant species in home gardens and evaluate different methods for obtaining this information

2) to evaluate the factors that contribute to agrobiodiversity in home gardens

3) to assess the relative contributions of different agroecosystems, home gardens and orchards, for Hymenoptera richness and 4) to design and evaluate an applied ethnoecological development initiative to improve income with horticultural practices that maintain and improve biodiversity and ecosystem services.

\section{Study Region}

Fieldwork was primarily conducted in the villages of Tosor $\left(42^{\circ} 09^{\prime} \mathrm{N}, 77^{\circ} 26^{\prime} \mathrm{E}\right.$, approximately $1623 \mathrm{~m}$ elevation) and Tamga $\left(42^{\circ} 08^{\prime} \mathrm{N}, 77^{\circ} 32^{\prime} \mathrm{E}\right.$, approximately $1675 \mathrm{~m}$ elevation), Jeti-Oguz Rayon (district), Issyk-Kul Oblast (state), Kyrgyz Republic, Central Asia, from in June 2003 until November 2006. The two villages are $12 \mathrm{~km}$ apart on the shore of Lake Issyk-kul [(1608 m shoreline) in Ter-Ghazaryan and Heinen 2006, ECONET 2008)]. The Issyk-kul Basin is part of the Tien Shan mountain range with elevations that reach $3500 \mathrm{~m}$ (Ter-Ghazaryan and Heinen 2006, ECONET 2008). The 
villages are part of the Issyk-kul UNESCO Man and Biosphere Reserve. For more information on the non-agricultural ecosystems of the region, see Krever et al. (1998) and Carpenter et al. (2001).

\section{Chapter Outline}

In the second chapter I reviewed home garden research as it pertains to agrobiodiversity conservation. I focused on an ethnoecological conceptual model that I suggested could be used as a tool for approaching home garden research to help ensure pertinent variables are being studied that are generally relegated to different disciplines.

In the third chapter I analyzed edible plant species and varietal diversity in home gardens using and comparing the effectiveness of different research methods. I used interviews, structured survey instruments, and full agroecosystem mapping to determine edible plant species diversity, and in the case of apples, variety diversity. Full garden mapping resulted in the identification of approximately $40 \%$ more species than were revealed in an interview context. The variation in mapped species diversity in home gardens was significantly explained by the proportion of species received from neighbors and relatives and self-propagated (28\%) and by the number of plots cultivated (36\%). Home gardens were more species diverse when home gardeners received more plants from others and less species diverse when household members had access to additional land that could be cultivated. I discussed the ramifications of different sampling methods and how the relationship of explanatory variables for species diversity in Kyrgyz home gardens differs 
from previously published research, with the conclusion that the differences are seemingly due to Soviet legacies.

Chapter four examines another dimension of biodiversity in home gardens, the diversity of Hymenoptera, many of which are pollinators of the cultivated crops described in chapter three. I surveyed Hymenoptera during apple bloom in home gardens and orchards over two years, investigating how species richness and abundance of total Hymenoptera, solitary bees, social bees, and wasps was related to overstory cover, overstory bloom, vegetation cover, average ground cover height, and agroecosystem management. Average height of vegetation was the best predictor of Hymenoptera richness and abundance and solitary bee abundance and richness. The results suggest that home gardens and orchards, as currently managed, support abundant and diverse pollinator communities, with few differences in community composition between management types.

Twelve hymenopterans from seven families collected during the course of the research documented in chapter four were new records for Kyrgyzstan. Six species were new records for Kyrgyzstan and six were new records for Issyk-kul district. These are described and documented in chapter five by listing each species in turn, noting the gender and number of specimens collected, locations and dates of collection and brief details of the species' distribution. 
In Chapter six I investigated the effectiveness of low-external input technology (LEIT) agricultural extension for home garden management practice improvement. Economic pressures to intensify cultivation in home gardens could impact management practices that currently promote the insect and cultivated plant diversity in Kyrgyz home gardens as documented in chapters three, four and five. The focus of LEIT is on integrating improved agricultural techniques into current practice to increase the sustainability of agriculture for farmers. Documenting and understanding current practices is improved by using an ethnoecological approach. Participants in the agricultural extension initiative had higher adoption rates than non-participants of management practices such as compositing, thinning of fruits, grafting, and seedling establishment, which can improve long-term yield, ecological sustainability and stability of home gardens. I discussed the importance of the selection of which management techniques to focus agricultural extension on based on ethnoecological research and agroecological principles and the contributions of mobilization activities, marketing, and improved access to credit to adoption rates. 


\section{LIST OF REFERENCES}

Aguilar-Støen, M., Moe, S.R., \& Camargo-Ricalde, S.L. (2009). Home gardens sustain crop diversity and improve farm resilience in Candelaria Loxicha, Oaxaca, Mexico. Hum. Ecol. 37:55-77.

Altieri, M.A. (2002). Agroecology: the science of natural resource management for poor farmers in marginal environments. Agr. Ecosyst. Environ. 93:1-24.

Altieri, M.A. (2004). Linking ecologists and traditional farmers in the search for sustainable agriculture. Front. Ecol. Environ. 2:35-42.

Altieri, M.A., Anderson, M.K., \& Merrick, L.C. (1987). Peasant agriculture and the conservation of crop and wild plant resources. Conserv. Biol. 1:49-58.

Armbrecht I., Rivera L., Perfecto I. (2005). Reduced diversity and complexity in the leaf-litter ant assemblage of Colombian coffee plantations. Conserv. Biol. 19:897-907.

Banaszak, J. (1992). Strategy for conservation of wild bees in an agricultural landscape. Agric. Ecosyst. Environ. 40:179-192.

Billeter R., Liira J., Bailey D., Bugter R., Arens P., Augenstein I., Aviron S., Baudry J., Bukacek R., Burel F., Cerny M., De Blust G., De Cock R., Diekötter T., Dietz H., Dirksen J., Dormann C., Durka W., Frenzel M., Hamersky R., Hendrickx F., Herzog F., Klotz S., Koolstra B., Lausch A., Le Coeur D., Maelfait J.P., Opdam P., Roubalova M., Schermann A., Schermann N., Schmidt T., Schweiger O., Smulders M.J.M., Speelmans M., Simova P., Verboom J., van Wingerden W.K.R.E., Zobel M., \& Edwards P.J. (2008). Indicators for biodiversity in agricultural landscapes: a pan-European study. J. Appl. Ecol. 45:141-150.

Buchmann S.L., \& Nabhan G.P. (1996). The Forgotten Pollinators. Island Press, Washington, D.C.

Carpenter, C., Fet, G. \& Fet, V. (2001). Tian Shan foothill arid steppe (PA0818). Terrestrial Ecoregions of the World.

http://www.worldwildlife.org/wildworld/profiles/terrestrial/pa/pa0818_full.html. Accessed 22 May 2008

Chelpakova J.M., \& Milko, D.M. (2004). Biologicheskoye rsnoobrazie nasekomych y nekotorye aspecty biosfery Issyk-kulskoy territorii. Practika Pyatogo Issyk-Kulskogo Simposiuma. (The insect biodiversity and some aspects of its conservation in the YsykKol territoty of Biosphere. Proceedings of the 5th Issyk-Kul Symposium.) Bishkek, Kyrgyzstan. 
Conklin, H. (1954). The Relation of Hanunuo Culture to the Plant World. Ph.D. Dissertation, Yale University, New Haven.

Davis, S.D., Heywood, V.H, \& Hamilton, A.C. (1994). Centres of plant diversity: A guide and strategy for their conservation. World Wide Fund for Nature (WWF) and IUCN - World Conservation Union, Cambridge, U.K.

Dietsch T.V., Perfecto I., \& Greenberg R. (2007). Avian foraging behavior in two different types of coffee agroecosystem in Chiapas, Mexico. Biotropica 39:232-240.

Dzhangaliev, A. D., Salova, T.N. \& Turekhanova, P.M. (2003). The wild fruit and nut plants of Kazakhstan. In: Janick, J. (ed), Wild Apple and Fruit Trees of Central Asia, Horticultural Reviews Volume 29. Jonh Wiley \& Sons, Inc., New Jersey.

Eastwood, A., Lazkov, G., \& Newton, A. (2009). The Red List of Trees of Central Asia. Fauna and Flora International, Cambridge, U.K.

ECONET (2008). Factsheet - Kyrgyzstan. In: Econet of Kyrgyzstan.

http://www.wwf.ru/data/asia/econet_maps/kyrgyzstaneng.doc. Accessed 21 May 2008

Fernandes, E.C.M. \& Nair, P.K.R. (1986). An evaluation of the structure and function of tropical homegardens. Agroforest. Syst., 21, 279-310.

Ford, R.I. (1994). The Nature and Status of Ethnobotany. $2^{\text {nd }}$ edn. Anthropological Papers, Museum of Anthropology, University of Michigan, No. 67, Ann Arbor.

Forsline, P.L., Aldwinckle, H.S., Dickson, E.E., Luby, J.J. \& Hokanson, S.C. (2003). Collection, maintenance, characterization, and utilization of wild apples of Central Asia. In: Janick, J. (ed), Wild Apple and Fruit Trees of Central Asia, Horticultural Reviews Volume 29. John Wiley \& Sons, Inc., New Jersey.

Gardner KE, \& Ascher J.S. (2006) Notes on the native bee pollinators in New York apple orchards. J. New York Entomol. Soc. 114:86-91.

Hall, M. (2001). Farming Systems and Poverty: Improving Farmers' Livelihoods in a Changing World. Food and Agriculture Organization of the United Nations, Rome.

Hylander, K. \& Nemomissa, S. (2008). Home garden coffee as a repository of epiphyte biodiversity in Ethiopia. Front. Ecol. Environ. 6:524-528.

IUCN (2009). 2009 IUCN Red List of Threatened Species. Version 2009.1. www.iucnredlist.org. Accessed 07 June 2009

Jain, S.K. (2000). Human aspects of plant diversity. Econ. Bot. 54:459-470. 
Kearns, C.A. (2001). North American dipteran pollinators: assessing their value and conservation status. Conserv. Ecol. 5:5. http://www.consecol.org/vol5/iss1/art52001 Accessed May 22, 2008.

Kearns, C.A., \& Inouye, D.W. (1997). Pollinators, flowering plants, and conservation biology. BioScience 47:297-307.

Kevan, P.G. (1999). Pollinators as bioindicators of the state of the environment: species, activity and diversity. Agric. Ecosyst. Environ. 74:373-393.

Klein, A., Steffan-Dewenter I., \& Tscharntke, T. (2003). Bee pollination and fruit set of Coffea canephora in relation to local and regional agroforestry management. J. Appl. Ecol. 40:837-845.

Krever, V., Pereladova, O., Williams, M. \& Jungius, H. (1998). Biodiversity conservation in Central Asia: An analaysis of biodiversity and current threats and initial investment portfolio. Wild Fund for Nature (WWF), Moscow. http://www.wwf.ru/resources/publ/book/eng/36. Accessed May 22, 2008.

Lerman, Z., \& Stanchin, I. (2004). Institutional changes in Turkmenistan's agriculture: impracts on productivity and rural incomes. Eurasian Geogr. Econ. 45:60-72.

Lobell, D.A., Burke, M.B., Tebaldi, C., Mastrandrea, M.D., Falcon, W.P. \& Naylor, R.L. (2008). Prioritizing climate change adaptation needs for food security in 2030. Science. 319:607-610.

Mas, A.H., \& Dietsch, T.V. (2004) Linking shade coffee certification to biodiversity conservation: butterflies and birds in Chiapas, Mexico. Ecol. Appl. 14:642-654

McGregor, S.E. (1976) Insect Pollination of Cultivated Crops. Washington, DC: USDA Agriculture Handbook No. 496, US Government Printing Office. http://gears.tucson.ars.ag.gov/book/. Accessed 2 October 2008.

Ministry of Environmental Protection (1998). Kyrgyz Republic biodiversity strategy and action plan. Ministry of Environmental Protection, Bishkek, Kyrgyz Republic.

Nabhan, G.P. (1985). Native crop diversity in Aridoamerica: conservation of regional gene pools. Econ. Bot. 39:387-399.

National Statistics Committee of the Kyrgyz Republic (2008). Sel'skoe khozyaistvo Kyrgyzskoy Respubliki 2005-2007 (Agriculture in the Kyrgyz Republic 2005-2007). National Statistical Committee of the Kyrgyz Republic, Bishkek.

Nazarea, V.D. (1999). Ethnoecology. University of Arizona Press, Arizona. 
Norris, K. (2008). Agriculture and biodiversity conservation: opportunity knocks. Conserv. Lett. 1:2-11.

Ostashko A., \& Currey R. (2007). Household Surveys in the Kyrgyz Republic, 2006: An Economic Profile of Home Gardeners. Mercy Corps Kyrgyzstan and Kompanion Financial Group, Bishkek, Kyrgyz Republic.

Partap U., \& Partap T. (2002). Warning signals from the apple valleys of the Hindu Kush-Himalayas: productivity concerns and pollination problems. International Centre for Integrated Mountain Development, Kathmandu, Nepal.

Perfecto I., Mas A., Dietsch T.V., \& Vandermeer J. (2003). Species richness along an agricultural intensification gradient: a tri-taxa comparison in shade coffee in southern Mexico. Biodivers. Conserv. 12:1239-1252.

Perfecto I., Vandermeer J., Mas A., Pinto L.S. (2005). Biodiversity, yield and shade coffee certification. Ecol. Econ. 54:435-446.

Perfecto, I., Rice, R., Greenberg, R. \& Van der Voolt, M. (1996). Shade coffee as refuge of biodiversity. BioScience. 46:598-608.

Pratt, C. (1988). Apple flower and fruit: morphology and anatomy. Hortic. Rev. 10:273308.

Primack, R.B. (1998). Essentials of Conservation Biology. $2^{\text {nd }}$ edn. Sinauer Associates, Massachusetts.

Raheem, D.C., Naggs, F., Preece, R.C., Mapatuna, Y., Kariyawasam, L., \& Eggleton, P. (2008). Structure and conservation of Sri Lankan land-snail assemblages in fragmented lowland rainforest and village home gardens. J. Appl. Ecol. 45:1019-1028.

Scott-Dupree, C.D., \& Winston, M.L. (1987). Wild bee pollinator diversity and abundance in orchard and uncultivated habitats in the Okanagan Valley, British Columbia. Can. Entomol. 119:735-745

Seeth, H.T., Chachnov, S., Surinov, A. \& Von Braun, J. (1998). Russian poverty: muddling through economic transition with garden plots. World Dev. 26:1611-1623.

Soberón, J., Rodríguez, P. \& Vázquez-Domínguez, E. (2000). Implications of the hierarchical structure of biodiversity for the development of ecological indicators of sustainable use. Ambio. 29:136-142.

Steffan-Dewenter, I. (2003). The importance of habitat area and landscape context for species richness of bees and wasps in fragmented orchard meadows. Conserv. Biol. 17:1036-1044. 
Steffan-Dewenter, I., \& Leschke, K. (2003). Effects of habitat management on vegetation and above-ground nesting bees and wasps of orchard meadows in Central Europe. Biodiv. Conserv. 12:1953-1968.

Steffan-Dewenter, I., \& Westphal, C. (2008). The interplay of pollinator diversity, pollination services and landscape change. J. Appl. Ecol. 45:737-741.

Ter-Ghazaryan, D., \& Heinen, J.T. (2006). Reserve management during transition: the case of Issyk-kul Biosphere and Nature Reserves, Kyrgyzstan. Environ. Pract. 8:11-23.

Tilman, D. (1996). Biodiversity: population versus ecosystem stability. Ecology 77:350-363.

Winfree R., Williams, N.M., Gaines, H., Ascher, J.S., Kremen, C. (2008). Wild bee pollinators provide the majority of crop visitation across land-use gradients in New Jersey and Pennsylvania, USA. J. Appl. Ecol. 45:794-803.

World Bank Kyrgyz Republic (2005). Farm structure and agricultural productivity. Kyrgyzstan Agriculture Sector: Policy Note 2. World Bank Country Office in the Kyrgyz Republic, Bishkek. 


\title{
CHAPTER II
}

\section{HOME GARDENS AND AGROBIODIVERSITY: AN ETHNOECOLOGICAL}

\section{APPROACH}

\begin{abstract}
Home gardens are important reservoirs of agrobiodiversity. Home garden systems are fundamentally different from large-scale agricultural systems, partly because of their small size, their proximity to people's homes, the daily use of products within them and low levels of external inputs. Researching home gardens requires a different approach because there are many factors that influence home gardeners' management decisions that are traditionally studied by different disciplines. While conservation scientists agree in the need to work across disciplines, with development organizations, and with farmers to address conservation issues posed by agricultural expansion and intensification, the challenge remains of precisely how to do this. Because agricultural systems are human created and managed, a logical approach to their study would be one that blends anthropological and ecological points of view. An overlooked ethnoecological model, the Landscape-Lifescape model, establishes a framework for more thorough studies that clearly elucidate and distinguish which factors exert pressure on management decisions of home gardeners, especially useful in the context of applied ethnobiology, anthropology and development studies. This model is described and the ramifications for biodiversity conservation and rural development applications is discussed.
\end{abstract}


Key words: agrobiodiversity; agriculture; home gardens; ethnoecology; socioecological systems

\section{Introduction}

The recent rise in global food prices has resulted in serious setbacks for reducing poverty and establishing food security for the 2.5 billion of the world's population who live on less than $\$ 2$ per day (Naylor \& Falcon 2008). Small farmers, such as home gardeners, produce the majority of food in the developing world (Hall 2001). For example, in the Russian Federation in 2006, 53\% (by value) of the country's total agricultural production came from home gardens, including $93 \%$ of the total potato output and $81 \%$ of fruit/berry yields (Sharashkin 2008). Home gardens are small-scale agroforestry systems with mixtures of trees, shrubs, herbs and other cultivated crops in areas surrounding households, maintained and managed by those in households (Fernandes \& Nair 1986). Home gardens occur in many countries worldwide, but differ regionally in species composition, structure, role in household and management practices (Lamont et al. 1999). Home gardens range from 0.1 ha to 1.0 ha (Nautiyal et al. 1998, Lamont et al. 1999, High \& Shackleton 2000). Home gardens are considered by some to be small-scale agroforestry systems (Sinclair 1999) while others recognize home gardens as specialized agroforestry systems subject to different rules of management because of their proximity to the house and the daily use of plant products within them (Alcorn 1981, Agelet et al. 2000). 
Home garden systems are fundamentally different from large scale agriculture: they use no chemical inputs, are not mechanized, and host high levels of diversity including agrobiodiversity, non-cultivated plant diversity, as well as insect, mollusc and bird diversity (e.g., Hylander \& Nemomissa 2008, Raheem et al. 2008). Improving smallholder farming systems is critical for reducing hunger and poverty through longterm growth in agricultural productivity (Hall 2001). Mitigating negative environmental effects that often accompany agricultural growth, such as agrobiodiversity and biodiversity loss, deterioration of ecosystem services, and contamination is a critical challenge for conservation science (Norris 2008).

Conservation scientists agree in the need to work across disciplines, with development organizations, and with farmers to address the conservation issues posed by agricultural expansion and intensification (Mascia et al. 2003, Altieri 2004, Norris 2008, Lowe et al. 2009). However, the challenge remains of precisely how to do this (Lowe et al. 2009). Agricultural ecosystems are human systems. Home garden management decisions are based on both global and local ecological factors, cultural norms and values, and socioeconomic realities of the land manager (Lamont et al. 1999, Mendez et al. 2001, Coomes \& Ban 2004, Aguilar-Støen et al. 2009). An overlooked ethnoecological model, the Landscape-Lifescape model, provides a framework that could be applied to home garden research to more clearly elucidate and distinguish which factors exert pressure on management decisions of home gardeners. 
Ethnoecology, like ethnobiology, is the study of how different cultural traditions perceive, cognize, use, and manage both the environment, and their knowledge of the environment, including the organisms within the environment (Ellen 2006). It draws on different "...disciplines and integrates them into a comprehensive methodology" (Ford 1999: 71). Ethnoecology seeks to enhance the understanding of the interaction of humans in their environments and provides a framework for understanding environmental management, agricultural sustainability, biodiversity conservation and intellectual property rights from the perspective of those managing, or as Altieri (2002) describes it, the "farmers rationale" and the scientific perspective, or the "scientific basis" (Nazarea 1999, Altieri 2002: 4). To do this, ethnoecology appeals to three broad sources of information: patterns of land use, species utilization and knowledge of human behavior. This review separates out home gardens as a specialized form of agriculture by describing current home garden research, with a focus on agrobiodiversity conservation, and demonstrates the potential of an ethnoecological approach for researching these complex systems.

Home garden research

An objective of home garden research is to identify the set of land use practices that involve an intentional combination of trees and agricultural crops on the same tract of land in some spatial arrangement (Sinclair 1999), as well as the explicit identification of which tree and agricultural species are utilized. Implicit in this goal is the identification of factors that influence land use practices, as well as which species are used. Home garden research differs from much ecological and cultural anthropological research in 
that it requires an understanding and documentation of cultural, social, and economic factors critical in determining management practices and an understanding and documentation of the role of ecology and individual species' taxonomy and growth requirements (Alcorn 1981, Lamont et al. 1999, Nazarea 1999, Jain 2000). Thus, home garden research exists in a multidisciplinary zone among ecology, sociology, anthropology and economics in its goal to assess the many factors influencing one tract of land.

Recently, home garden research has been conducted in two radically different systems: among more traditional cultures in the tropics (Americas, Africa, South East Asia and India) and among modern societies in primarily temperate regions (North America and Europe). Home garden studies can be classified into six broad categories:

1) description of plant species and their uses (e.g., Lamont et al. 1999, Agelet et al. 2000),

2) documentation of ecological processes within home gardens (Baijukya \& de Steenhuijsen Piters 1998, Gajaseni \& Gajaseni 1999) and the comparison of gardens to intact forests (Boster 1983, Vickers 1983),

3) documentation of user-defined zones of management (Westmacott 1992, Jugerius 1998, Withrow-Robinson 1999, De Clerck \& Negreros-Castillo 2000, Backes et al. 2001, Mendez et al. 2001),

4) documentation of socioeconomic variables that may influence management (Nautiyal et al. 1998, High \& Shackleton 2000, Shrivastava \& Heinen 2005, Kabir \& Webb 2009), 
5) eliciting of aesthetic perceptions (Smardon 1988, Nassauer 1995, Grove \& Burch 1997, Nassauer 1998) and

6) more holistic studies that consider many of the above variables (Alcorn 1981, Coomes \& Ban 2004, Aguilar-Støen et al. 2009).

The classification is somewhat arbitrary in that many of the studies mentioned above often overlap in their content. However, this classification is useful in that it categorizes the primary focal point of the studies and illustrates the discrepancy between the limited scope of the factors explicitly researched in a given study and the broad range of factors that actually influence home garden management (Altieri 2002).

The majority of these studies are primarily descriptive, in that they identify species grown and used (Lamont et al. 1999, Agelet et al. 2000), or document single variables that might influence management practices (Nautiyal et al. 1998, High \& Shackleton 2000). As mentioned above, many factors influence home garden management and have ecological, social, cultural and economic dimensions. The documentation of user-defined management zones (Westmacott 1992, Jugerius 1998, Withrow-Robinson 1999, De Clerck \& Negreros-Castillo 2000, Backes et al. 2001, Mendez et al. 2001) and the eliciting of aesthetic perceptions (Smardon 1988, Nassauer 1995, Grove \& Burch 1997, Nassauer 1998) represent more inclusive approaches to understanding management decisions on the following premise: the organization of space is coded by the way it is experienced and molded by and through ongoing social relations (Green 1995). Several authors (Vickers 1983, Nautiyal et al. 1998, Lamont et al. 1999, Withrow-Robinson 1999, High \& Shackleton 2000, Mendez et al. 2001) conclude that space is coded by 
culture but also by economic factors, and that species composition and garden zonation is flexible, varying with social and economic changes. However, only High \& Shackleton (2000) and Nautiyal and co-authors (1998) have explicitly quantified this phenomenon. Home garden researchers stuggle with adequately addressing the multiple factors and complex interaction of these factors that influence management.

\section{Ethnoecology}

Ethnoecological approaches (see Posey 1984, Brush 1992, Nazarea 1998) have re-shaped ecological and agricultural studies of societies, with their focus on the "depth of people's knowledge of their environments" (Sillitoe 2006:152), indigenous rights, and participatory approaches that they have replaced other kinds of approaches in environmental and ecological anthropology (Ellen 2006:14). Ethnoecology grew somewhat in response to the discounting of traditional ecological knowledge and management practices employed by indigenous cultures as random, destructive and primitive (Nazarea 1999, Sillitoe 2006). Conklin (1954) introduced the notion of an "ethnoecological approach" and since that time ethnoecology has developed considerably, drawing from different disciplines, including the closely related field of historical ecology, but also cultural ecology, ecological and environmental anthropology, cognitive anthropology, botany, ecology, landscape ecology and agroecology (Ford 1994, Balée 1998, Ford 1999, Nazarea 1999, Altieri 2002, Ellen 2006). What separates ethnoecology and other ethnosciences from their most closely related research program, historical ecology (see Balée 2006), is ethnoecology's base in cognitive/linguistic 
principles, and focus on people's perception, or cognition, of landscapes and the environment and not only as an agent of change on the landscape (see Nazarea 2006).

A conceptual model that illustrates an ethnoecological approach is Nazarea's LandscapeLifescape model, which addresses the complexity of studying home garden systems (Nazarea 1999). Nazarea's model incorporates a way of explicitly looking at the multiple local factors that influence land management, yet is flexible enough to permit its application to the myriad home garden systems in the world. In principle, this approach to home garden research allows for more thorough studies that clearly elucidate and distinguish which factors exert the most pressure on management decisions of home gardeners from both the perspective of the home gardener and the scientific perspective. Because of the breadth of factors influencing home gardens that are typically studied by different disciplines, it is a challenge to adequately address all factors. Home garden researchers need to improve their description, documentation and testing of the cultural, economic and ecological factors that influence management decisions for both the individual gardener and at the community level.

Ethnoecology has been described as "a way of looking" at land, and the relationship humans have with the environment, that incorporates the role of cognition in shaping behavior and the actions of management (Nazarea 1999). It deals with human cognition of environmental components (e.g., plants, animals, water, soils), the classification of its components within a given environment and the actions that people take or do not take to manage those environmental components (Nazarea 1999). Ethnoecological 
investigations have sought to understand "local" perceptions and landuse practices (Nazarea 1999). Many ethnoecological studies are concerned with the management of natural resources (biotic and abiotic) and practitioners seek to make their research part of international efforts of biodiversity protection and the recognition of indigenous knowledge (Ford 1994). Nazarea proposed an enthnoecological conceptual model for identifying and understanding resource management practices at the local level that integrates ecological and anthropological points of views, which is appropriate for home garden research (Nazarea-Sandoval 1995, Nazarea 1999, Altieri 2002).

The Landscape-Lifescape model

The basic premise of the Landscape-Lifescape model is that management practices are the product of both the biotic and abiotic components of land (landscape) and the "superimposition of human intentions, purposes and viewpoints over environmental features and the resulting patterns of production, consumption and distribution" on land (lifescape) (Nazarea 1999: 91). Put another way, the landscape represents value neutral components of land: energy flows, species pools, nutrient cycling and physical factors such as soils, slopes and river valleys and the lifescape is how human cognition, decisions and actions manifest themselves on land given specific biotic and abiotic resources (Fig 1). A lifescape can be any manifestation of human intention on land; in this case a home garden.

In Nazarea's (1999) model, ecological variables are defined separately from socioeconomic and cultural variables (Fig 1). The ecological variables (e.g., biotic and 
abiotic elements; material and energy flows) are categorized as the landscape. The landscape and the ecological variables are described as being neutral. That is, these variables, when taken as a whole, are essentially the template for human action: the raw materials. The model indicates that natural resources can contribute to the lifescape both directly and indirectly, through a filter of human cognition. Nazarea defines variables such as cultural values and norms, institutions and available technologies, as well as activities and goods produced as contributing to the structure of the lifescape. These variables contribute to the pattern of consumption, production and reproduction for a given locale. Issues of global concern such as conservation, sustainability and degradation are depicted as resource management practices, which in the model are situated between the lifescape and the landscape. The manner in which biotic and abiotic variables are manipulated given specific cultural, social and economic circumstances is a management practice. The result of this manipulation (management practice) is an alteration of the ecological variables Nazarea characterizes as the landscape.

The model provides for the explicit identification of the natural resources available for use and which are actually exploited. It also encourages description and understanding of the cultural, economic, political and social circumstances of the people who are the subjects of the research. The model implies human interaction with land is continuous and iterative across time. The iterative nature of this model makes it valuable for addressing questions of biodiversity conservation and sustainability. The lifescape is directly linked with the landscape. The degradation of the lifescape limits the "neutral" components of the landscape that are available for humans to act on. The improvement 
of the lifescape (e.g., increased biodiversity) enhances the landscape (sum of environmental components) upon which humans can then again act. This model for understanding land management does not eliminate other approaches to home garden research and does not provide a definitive outline of research methods. I believe this is its strength. It provides a way to identify and evaluate factors that will explain the interaction of humans with their environment. The problems with current home garden research and the potential benefits of employing Nazarea's Landscape-Lifescape model will be illustrated by the review of work on the role of home gardens in the conservation of biodiversity.

Home garden research and biodiversity Biodiveristy loss directly and negatively impacts human populations due to the fact that we depend on the natural environment for food, medicines, raw materials and other resources such as water and their effects of loss are cascading- that is, many independent factors collectively exacerbate biodiversity loss to a greater degree than each individual threat (Primack 1998). Home gardens have been identified as playing a critical role in the preservation of genetic variability for many agricultural species, which constitutes the foundation of future food availability (Ford 1994). It is not surprising that as concern over both food security and biodiversity loss mounts, home gardens have received more attention; especially for the role they play in providing food and in conserving domesticated plant diversity. 
Biodiversity refers to the number of species in a given area, the genetic diversity of those species and also the diversity of life forms, and it plays a role in stabilizing community and ecosystem processes (Tilman 1996, Primack 1998). Applying biodiversity concepts in human-occupied space to issues of resource sustainability is challenging due to the mixture of both ecological and human components (Soberón et al. 2000). Nonetheless, home gardens play two major roles in the conservation of biodiversity at two different scales: within the garden and the garden itself. There can be many different species and varieties of plants within gardens (e.g., Nabhan 1985) while the gardens themselves can serve as habitat for other plant, insect and animal species that are not intentionally planted or tended by households (e.g., Perfecto et al. 1996, Hylander and Nemomissa 2008, Raheem et al. 2008). Here, research concerning the former will be considered.

Home gardens and other forms of agroecosystems are important to the conservation of plant resources when it is considered that "these plant resources are directly dependent upon management by human groups, thus, they have evolved in part under the influence of farming [land use] practices shaped by particular cultures" (Altieri et al. 1987: 49). Thus, diverse cultures in a region apply distinct folk-scientific and aesthetic criteria to the selection of plants (Jain 2000, Nabhan 1985). Nabhan (1985) and Cleveland and coauthors (1994) have identified three reasons why traditional varieties of plants are valuable to conserve:

1) though traditional varieties may not be high yielders, many have adaptations such as insect and pathogen resistance or to growing on marginal lands that might be important for continued food production as environmental degradation continues, 
2) though many varieties may not offer high economic returns, native crops and special foods may be symbols for cultural identity (Dove 1999) and

3) many traditional varieties exist in geographically and ecologically distinct populations and have diverse genetic composition between and within populations (Cleveland et al. 1994).

The genetic diversity of crops within any region are related to the duration and continuity of agriculture, diversity of native plant species to exploit, cultural diversity and introgression of crops with native (wild) relatives (Nabhan 1985). Several authors have sought to identify cultivars and to determine how they are distinguished by farmers (cultivators) (Boster 1985, Brush et al. 1995, Clawson 1985, Cleveland et al. 2000, Elias et al. 2000, Soleri \& Cleveland 2001). These authors have determined the criteria to be primarily phenotypical. Some authors have then studied the phenotypes that are selected for by farmers and have sought to identify underlying genetic diversity (Jianchu et al. 2001, Soleri \& Cleveland 2001).

Two mechanisms have been proposed for the conservation of biological diversity in crop plants (native varieties): ex situ and in situ conservation (Nabhan 1985, Altieri et al. 1987, Altieri \& Merrick 1987, Cleveland et al. 1994). Ex situ conservation is the collection of propagules from existing varieties and storing them in order to preserve germplasm. Criticisms of ex situ conservation are that the evolutionary process of these plants halted (Altieri \& Merrick 1987) and the plants are removed from the original cultural-ecological (human-land interface) context in which they evolved (Nabhan 1985). 
Altieri and Merrick (1987) and Altieri and co-authors (1987) conclude that a combination of both methods offers the best opportunity for the conservation of biodiversity and germplasm diversity. They also state the conservation of traditional agroecosystems and surrounding ecosystems is the best strategy for successful in situ preservation of crop germplasm. In order to conserve traditional agroecosystems, of which home gardens are a type, it is necessary to fully understand the factors that influence management dynamics. Home garden research has identified many of these factors in many different regions.

Home garden research has identified the extent of biodiversity in home gardens (e.g., Lamont et al. 1999, Agelet et al. 2000, Kabir \& Webb 2009). Research in home gardens has also concluded that while biodiversity is high in home gardens, it is often not as high as intact habitat (e.g., Boster 1983, Vickers 1983). However, researchers have also found that while absolute biodiversity may not be higher in home gardens (interspecies diversity), intraspecies diversity is higher and the diversity of species at the scales larger than the home garden, the landscape scale, is higher (Boster 1983, Clawson 1985). Intraspecies diversity is attributed, in part, to farmers seeking to minimize the risk of crop failure by planting several varieties so that yields are stable (Altieri et al. 1987, Brush et al. 1995), culinary preferences, and the maintenance of traits with culture value that maintain traditions and social relations (Soleri and Smith 1999). However, factors influencing folk variety (landrace) retention are not well researched (Cleveland et al. 1994, Soleri and Smith 1999). The direct link between economic returns of certain crops and the availability of markets for plant products with species selection by home 
gardeners has been established (High \& Shackleton 2000, Nautiyal et al. 1998).

Decreases in the biodiversity of home gardens due to changes in social relations and the loss of traditional ecological knowledge have also been documented (Agelet et al. 2000, Cleveland et al. 1994). However, many variables that influence biodiversity within home gardens are still poorly understood, especially those that are potentially more influenced by cultural dynamics. Perhaps home garden research is not adequately addressing the issues that would contribute to the long-term sustainability of these systems for the preservation of crop genetic resources.

Application of the Landscape-Lifescape model Nazarea's Landscape-Lifescape model (1999) could help address some of the shortcomings of current home garden research as it pertains to the conservation of biological diversity. Altieri and Merrick (1987) identified inadequate sampling procedures (see also Stamps \& Linit 1999) and the difficulty of identifying the factors that influence the persistence of genetic resources in traditional agroforestry systems as problems with relying on in situ conservation. When the actual status of biodiversity and the factors that influence the persistence of genetic resources cannot be adequately identified, there are few assurances that the genetic resources can be conserved. Some of these problems might be overcome by implementing a model for research, such as Nazarea's (1999), that links cultural, social, economic and ecological variables. Nazarea's model calls for the identification of resources that are available for exploitation by humans (landscape) and the result of this exploitation (lifescape). Critically for in situ biodiversity conservation efforts, Nazarea's model illustrates that landscapes as perceived 
by those managing them ("cognition") may or may not result in an "action," that leaves a trace on the landscape (Fig. 1). Understanding home gardeners' perceptions of their home garden, environmental factors and processes, and the myriad of factors that influence home gardeners' decision making provides a basis for interventions with the potential to improve livelihoods and in situ biodiversity conservation. Many of the variables addressed in Nazarea's model do not necessarily require resources (time, money, etc.) above and beyond those home garden studies that are already being performed. Many researchers perform in-depth interviews but neglect to assess economic status. Others assess economic issues without attempting to understand the persistence plants that are not actively traded or sold in the garden. However, some factors are more difficult to document and understand and will require time for explicit study, such as understanding cultural cognition of land and determining culturally relevant cues to sustainability (Nazarea 1999). The Landscape-Lifescape model will not be a panacea for home garden research, but it can provide a framework for more thorough studies.

Nazarea (1999) warned against globalizing local phenomena and advocated the need for understanding points of view and the capacity for self-determination at the local scale. She stated that generalizing situated systems to "pan-human" categories and systems of classification without meaningful context ("un-situated") negates the implications of local self-determination and local solutions to biodiversity conservation. I do not propose the application of her model for the development of pan-human categories and systems of classification. I propose the application of her model as a global research framework for scientists and development workers from multiple disciplines to understand local systems 
that would ensure pertinent variables are being studied in home gardens so that organizations that operate on a global scale have a more thorough understanding of local resource management systems that produce food. The model permits the investigator to better develop research about the variation in home garden systems by consciously addressing the interaction of the human component and the biological component of home gardens: the ethnoecological approach.

\section{Concluding Remarks}

With the proposition that home gardens and other agroforestry systems can serve as an in situ reservoir for biodiversity, many non-governmental and governmental agencies are seeking ways to conserve existing agroecological systems. However, with increasing food insecurity, climate change, and calls for agricultural intensification, in situ conservation of agrobiodiversity faces serious challenges (Lobell et al. 2008, Norris 2009). Across disciplines, there is consensus that food demand is increasing and that will put pressure on the ecological integrity of agricultural systems. Most small farmers, home gardeners, live in resource-poor areas in environments that are already ecologically vulnerable and more at-risk to ecological degradation (Altieri 2002, Lobell et al. 2008, Norris 2008). Employing a model for research such as Nazarea's (1999) conceptual model for understanding landscape-lifescape integration might help address why certain management practices are successful and why others fail to inform biodiversity conservation and efforts to preserve and improve agricultural livelihoods. 


\section{Acknowledgments}

The author would like to thank David Lee, Suzanne Koptur, William Vickers and Bradley Bennett for comments on early drafts. The author was supported, in part by the United States Environmental Protection Agency (EPA) under the Science to Achieve Results (STAR) Graduate Fellowship Program, Florida International University’s Presidential Enhancement Award, the International Institute of Education's Fulbright Program, and the National Geographic Society Conservation Trust (C61-05). This publication is not officially endorsed by EPA and may not reflect the views of the agency. 


\section{LIST OF REFERENCES}

Agelet, A., Bonet, M.A. \& Vallès, J. (2000). Homegardens and their role as a main source of medicinal plants in mountain regions of Catalonia. Econ. Bot., 54, 295-309.

Aguilar-Støen, M., Moe, S.R., \& Camargo-Ricalde, S.L. (2009). Home gardens sustain crop diversity and improve farm resilience in Candelaria Loxicha, Oaxaca, Mexico. Hum. Ecol., 37, 55-77.

Alcorn, J.A. (1981). Huastec non-crop resource management: implications for prehistoric rain forest management. Hum. Ecol., 9, 395-417.

Altieri, M.A. (2002). Agroecology: the science of natural resource management for poor farmers in marginal environments. Agr. Ecosyst. Environ., 93, 1-24.

Altieri, M.A. (2004). Linking ecologists and traditional farmers in the search for sustainable agriculture. Front. Ecol. Environ., 2, 35-42.

Altieri, M.A., Anderson, M.K. \& Merrick, L.C. (1987). Peasant agriculture and the conservation of crop and wild plant resources. Conserv. Biol., 1, 49-58.

Altieri, M.A. \& Merrick, L.C. (1987). In situ conservation of crop genetic resources through maintenance of traditional farming systems. Econ. Bot., 41, 86-96.

Backes, M.M. (2001). The role of indigenous trees for the conservation of biocultural diversity in traditional agroforestry land use systems: the Bungoma case study. Agroforest. Syst., 52, 119-132.

Baijuka, F.P. \& de Steenhuijsen Piters, B. (1998). Nutrient balances and their consequences in the banana-based land use systems of Bukoba district, northwest Tanzania. Agr. Ecosyst. Environ., 71, 147-158.

Balée, W. (1998). Historical Ecology. Columbia University Press, New York.

Balée, W. (2006). The research paradigm of historical ecology. Annu. Rev. Anthropol., $35,75-98$.

Brush, S.B. (1992). Ethnoecology, biodiversity and modernization in Andean potato agriculture. J. Ethnobio., 20, 269-299.

Brush, S.B., Kesseli, R., Ortega, R., Cisneros, P., Zimmerman, K. \& Quiros, C. (1995). Potato diversity in the Andean center of crop domestication. Conserv. Biol., 9, 11891198. 
Boster, J.S. (1983). A comparison of the diversity of Jivaroan gardens with that of the tropical forest. Hum. Ecol., 11, 47-68.

Boster, J.S. (1985). Selection for perceptual distinctiveness: evidence from Aguaruna cultivars. Econ. Bot., 39, 310-25.

Clawson, D. (1985). Harvest security and interspecific diversity in traditional tropical agriculture. Econ. Bot., 39, 56-67.

Cleveland, D.A., Soleri, D. \& Smith, S. (1994). Do folk crop varieties have a role in sustainable agriculture. BioScience., 44, 740-751.

Cleveland, D.A., Soleri, D. \& Smith, S. (2000). A biological framework for understanding farmers' plant breeding. Econ. Bot., 54, 377-394.

Conklin, H. (1954). The Relation of Hanunuo Culture to the Plant World. Ph.D. Dissertation, Yale University, New Haven.

Coomes, O.T. \& Ban, N. (2004). Cultivated plant species diversity in home gardens of an Amazonian peasant village in northeastern Peru. Econ. Bot., 58, 420-434.

De Clerck, F.A.J. \& Negreros-Castillo, P. (2000). Plant species of traditional Mayan homegardens of Mexico as analogs for multistrata agroforests. Agroforest. Syst., 48, 303-317.

Dove, M. (1999). The agronomy of memory and the memory of agronomy: ritual conservation of archaic cultigens in contemporary farming systems. In: Ethnoecology (ed. Nazarea, V.D.). University of Arizona Press, Arizona.

Ellen, R. (2006). Introduction. In: Ethnobiology and the Science of Humankind (ed. Ellen, R.). Blackwell Publishing, Oxford, pp. 1-28.

Elias, M., Riva, L. \& McKey, D. (2000). Perception and management of cassava (Maniot esculenta CRANTZ) diversity among Makushi Amerindians of Guyana (South America). Ethnobiology., 20, 239-265.

Fernandes, E.C.M. \& Nair, P.K.R. (1986). An evaluation of the structure and function of tropical homegardens. Agroforest. Syst., 21, 279-310.

Ford, R.I. (1994). The Nature and Status of Ethnobotany. $2^{\text {nd }}$ edn. Anthropological Papers, Museum of Anthropology, University of Michigan, No. 67, Ann Arbor.

Ford, R.I. (1999). Ethnoecology serving the community: a case study for Zuni Pueblo, New Mexico. In: Ethnoecology (ed. Nazarea, V.). University of Arizona Press, Arizona, pp.71-87. 
Gajaseni, J. \& Gajaseni, N. (1999). Ecological rationalities of the traditional

homegarden system in the Chao Phraya Basin, Thailand. Agroforest. Syst., 46, 3-23.

Green, N. (1995). Looking at the landscape: Class formation and the visual. In: The Anthropology of Landscape: Perspectives on Place and Space (eds. Hirsch, E. \& O’Hanlon, M.). Clarendon Press, Oxford.

Grove, J. M. \& Burch Jr., W.R. (1997). A social ecology approach and applications of urban ecosystem and landscape analyses: a case study of Baltimore, Maryland. Urban. Ecosyst., 1, 259-275.

Hall, M. (2001). Farming Systems and Poverty: Improving Farmers' Livelihoods in a Changing World. Food and Agriculture Organization of the United Nations, Rome.

High, C. \& Shackleton, C.M. (2000). The comparative value of wild and domestic plants in home gardens of a South African rural village. Agroforest. Syst., 48, 141-156.

Hylander, K. \& Nemomissa, S. (2008). Home garden coffee as a repository of epiphyte biodiversity in Ethiopia. Front. Ecol. Environ., 6, 524-528.

Jain, S.K. (2000). Human aspects of plant diversity. Econ. Bot., 54, 459-470.

Jianchu, X., Yongping, Y., Yingdong, P., Ayad, W.G. \& Eyzaguirre, P.B. (2001). Genetic diversity in taro (Colocasia esculenta Schott), Araceae, in China: an ethnobotanical and genetic approach. Econ. Bot., 55, 14-31.

Jugerius, P.D. (1998). Indigenous knowledge of landscape - ecological zones among traditional herbalists: a case study in Keiyo District, Kenya. GeoJournal., 44, 51-60.

Kabir, M.E. \& Webb, E.L. (2009). Household and homegarden characteristics in southwestern Bangladesh. Agroforest. Syst., 75, 129-145.

Lamont, S.R., Eshbaugh W.H., \& Greenberg, A.M.. (1999). Species composition, diversity and use of homegardens among three Amazonian villages. Econ. Bot., 53, 312326.

Lobell, D.A., Burke, M.B., Tebaldi, C., Mastrandrea, M.D., Falcon, W.P. \& Naylor, R.L. (2008). Prioritizing climate change adaptation needs for food security in 2030. Science., $319,607-610$.

Lowe, P., Witman, G., \& Phillipson, J. (2009). Ecology and the social sciences. J. Appl. Ecol., 46, 297-305.

Mascia, M.B., Brosius, J.P., Dobson, T.A., Forbes, B.C., Horowitz, L., McKean, M.A., \& Turner, N.J. (2003) Conservation and the social sciences. Conserv. Biol., 17, 649-650. 
Mendez, V.E., Lok, R. \& Somarriba, E. (2001). Interdisciplinary analysis of homegardens in Nicaragua: micro-zonation, plant use and socioeconomic importance. Agroforest. Syst., 51, 85-96.

Nabhan, G.P. (1985). Native crop diversity in Aridoamerica: conservation of regional gene pools. Econ. Bot., 39, 387-399.

Nassauer, J.I. (1995). Messy ecosystems, orderly frames. Landscape. J., 14, 161-170.

Nassauer, J.I. (1998). Landscape care: perceptions of local people in landscape ecology and sustainable development. Paper Presented at the Annual Meeting of the International Federation of Landscape Architects, Boston.

Nautiyal, S., Maikhuri, R.K., Semwal, R.L., Rao, K.S. \& Saxena, K.G. (1998).

Agroforestry systems in the rural landscape - a case study in Garhwal Himalaya, India. Agroforest. Syst., 41, 151-165.

Naylor, R. \& Falcon, W. (2008). Our daily bread. Boston. Rev., 33, 13-18.

Nazarea, V.D. (1999). Ethnoecology. University of Arizona Press, Tucson.

Nazarea, V.D. (1998). Cultural Memory and Biodiversity. University of Arizona Press, Tucson.

Nazarea-Sandoval, V. D. (1995). Local knowledge and decision making in the Phillipines. Cornell University Press, Ithaca.

Norris, K. (2008). Agriculture and biodiversity conservation: opportunity knocks. Conserv. Lett., 1, 2-11.

Perfecto, I., Rice, R., Greenberg, R. \& Van der Voolt, M. (1996). Shade coffee as refuge of biodiversity. BioScience., 46, 598-608.

Posey, D. (1984). Ethnoecology as applied anthropology in Amazonian development. Hum. Organiz., 43, 95-107.

Primack, R.B. (1998). Essentials of Conservation Biology. $2^{\text {nd }}$ edn. Sinauer Associates, Massachusetts.

Raheem, D.C., Naggs, F., Preece, R.C., Mapatuna, Y., Kariyawasam, L., \& Eggleton, P. (2008). Structure and conservation of Sri Lankan land-snail assemblages in fragmented lowland rainforest and village home gardens. J. Appl. Ecol., 45, 1019-1028.

Sharashkin, L. (2008). The socioeconomic and cultural significance of food gardening in the Vladimir region of Russia. Ph.D. Dissertation, University of Missouri, Columbia. 
Shrivastava, R.J., \& Heinen, J.T. (2005). Migration and home gardens in the Brahmaputra Valley, Assam, India. J. Ecol. Anthropol., 9, 20-34.

Sillitoe, P. (2006). Ethnobiology and applied anthropology: rapprochement of the academic with the practical. In: Ethnobiology and the Science of Humankind (ed. Ellen, R.). Blackwell Publishing, Oxford, pp. 147-176.

Sinclair, F.L. (1999). A general classification of agroforestry practice. Agroforest. Syst., 46, 161-180.

Smardon, R.C. (1988). Perception and aesthetics of the urban environment: review of the role of vegetation. Landscape. Urban. Plan., 15, 85-106.

Soberón, J., Rodríguez, P. \& Vázquez-Domínguez, E. (2000). Implications of the hierarchical structure of biodiversity for the development of ecological indicators of sustainable use. Ambio., 29, 136-142.

Soleri, D. \& Cleveland, D. A. ( 2001). Farmers' genetic perceptions regarding their crop populations: a example with maize in the central valleys of Oaxaca. Econ. Bot., 55, 106128.

Soleri, D. \& Smith, S.E. (1999) Conserving folk crop varieties. In: Ethnoecology (ed. Nazarea, V.D.). University of Arizona Press, Arizona.

Stamps, W.T. \& Linit, M.J.. (1999). The problem of experimental design in temperate agroforestry. Agroforest. Syst., 44, 187-196.

Tilman, D. (1996). Biodiversity: population versus ecosystem stability. Ecology., 77, 350-363.

Vickers, W.T. (1983). Tropical forest mimicry in swiddens: a reassessment of Geertz's model with Amazonian data. Hum. Ecol., 11, 35-45.

Wesmacott, R. (1992). African-American gardens and yards in the Rural South. University of Tennessee Press, Tennessee.

Withrow-Robinson, B., Hibbs, D.E., Gypmantasiri, P. \& Thomas, C. (1999). A preliminary classification of fruit-based agroforestry in a highland area of northern Thailand. Agroforest. Syst., 42, 195-205. 
Figure 1. The Landscape-Lifescape conceptual model for ethnoecological research (adapted from Nazarea 1999:92).

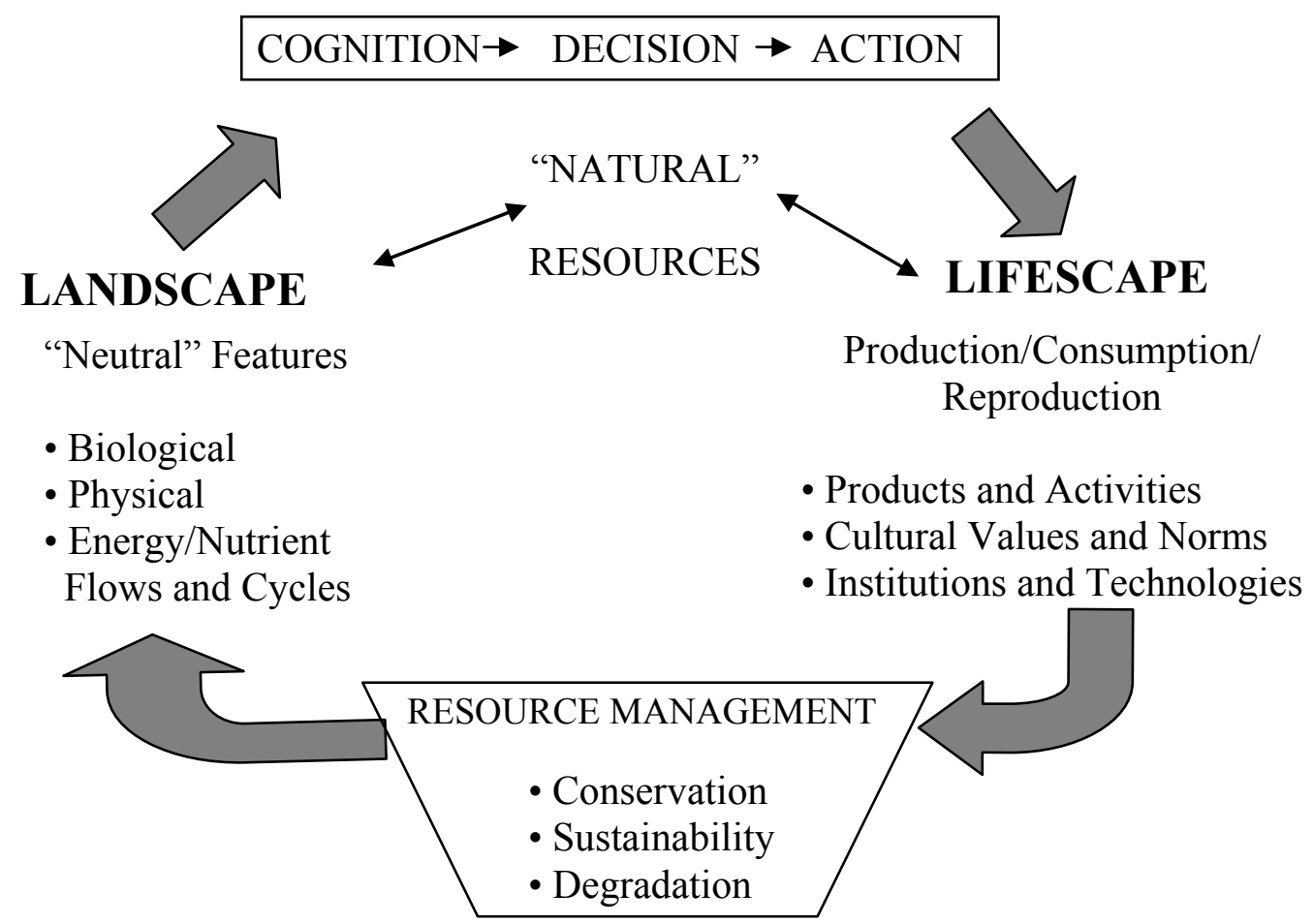




\title{
CHAPTER III
}

\section{EDIBLE PLANT SPECIES DIVERSITY IN KYRGYZ HOME GARDENS}

\begin{abstract}
The role of home gardens in the conservation of agrobiodiversity in Kyrgyzstan is unknown, but could be important given the number of different crop relatives, especially fruit tree crops, that grow wild, which provide residents with the opportunity to introduce these species into their gardens. I surveyed edible plant species and apple variety diversity by using interviews, structured survey instruments, and full agroecosystem mapping. Temperate home gardens in Kyrgyzstan are diverse with an average of 24 edible plant species per home garden, more diverse than some tropical home gardens, and that plant material received from others (relatives and neighbors) and number of additional plots owned were the best predictors of the diversity status of cultivated plants. Received plant material was positively related to the diversity of edible plants while additional plots owned was negatively related. The relationship of explanatory variables to mapped fruit species diversity in Kyrgyz home gardens, especially the variables of home garden size, additional plots owned, and age of home garden, differed from similar studies in primarily tropical home garden agroecosystems. Different methods used to document cultivated species diversity yield different results; mapping home gardens with members of the household revealed 50\% more species than in an interview context. The results demonstrate that methods for collecting information about species diversity in home gardens need to be carefully considered with full garden mapping with
\end{abstract}


participation of household members being the best method and that factors important to explaining home garden diversity in other parts of the world do not apply or have inverted relationships when applied to Kyrgyz home gardens, perhaps to due Soviet legacies.

\section{Introduction}

The conservation of indigenous cultigens, especially fruit and nut species, has unique importance in Kyrgyzstan, a former Soviet Republic, in the heart of Central Asia. The mountains of Central Asia were designated as a "hotspot" for global biodiversity in 1995, due, in part, to the more than 300 fruit and nut species that grow wild, some of which are wild progenitors of globally important crop species (Davis et al. 1995, Eastwood et al. 2009). Dozens of crop wild relatives that are valuable sources of genetic material for crop improvement grow wild in Kyrgyzstan, such as apple,, apricot, pear, cherry, plum, many species of raspberry and currant, grape and the nuts: almond, pistachio, and walnut (MEP 1998, Dzhangaliev et al. 2003, Eastwood et al. 2009) (Appendix 1). Additionally, the northern regions of Kyrgyzstan were important corridors for the Silk Trade Route over the course of many centuries, and movement of cultivars, via trade, has been ongoing over that time (Anonymous 1993, Forsline et al. 2003). The role of home gardens in the conservation of agrobiodiversity in Kyrgyzstan is unknown, but could be important given the number of different crop relatives, especially fruit tree crops, that grow wild, providing households with the opportunity to introduce these species into their gardens. 
Home gardens are small-scale agroforestry systems with mixtures of trees, shrubs, herbs and other cultivated crops in areas surrounding households, maintained and managed by those in households (Fernandes \& Nair 1986). Home gardens, with different combinations of trees, shrubs, and other crops are a type of small-scale agricultural system that occurs throughout the world with the commonality being that they are based around the household with daily use of plant products within them (Alcorn 1981, Agelet et al. 2000, Aguilar-Støen et al. 2009). Home gardens are considered by some to be small-scale agroforestry systems (Sinclair 1999) while others recognize home gardens as specialized agroforestry systems subject to different rules of management due to their proximity to the house and the daily use of plant products within them (Alcorn 1981, Agelet et al. 2000). Recent research in tropical home gardens document species composition, diversity of cultivated and non-cultivated plants, their uses, and demonstrate that home gardens are sites of high species diversity and can play a role for in situ biodiversity conservation (Lamont et al. 1999, Agelet et al. 2000, Coomes and Ban 2004, Kumar and Nair 2004, Aguilar-Støen et al. 2009). Studies in tropical systems have also documented ecological processes within home gardens (Baijuka and de Steenhuijsen Piters 1998, Gaijaseni and Gaijaseni 1999) and both cultural and socioeconomic factors that influence management practices (Nautiyal et al. 1998, Lamont et al. 1999, High and Shackleton 2000, Coomes and Ban 2004, Shrivastava and Heinen 2005, Aguilar-Støen et al. 2009, Kabir and Webb 2009).

Home gardens in temperate Kyrgyzstan are poorly known and have not been well researched. Molodogazieva and Spoor (1997) state that any study in the realm of human 
ecology, which home gardens are, will suffer because of the lack of attention to the field in the Soviet period and the lack of differentiation among ethnicities (Molodogazieva and Spoor 1997, Tchoroev 2002). It is also challenging to obtain historical information since much was destroyed and deciphering ethnographies from Soviet times and literature pertaining to ethnic Kyrgyz as a result of the strong influence of communist editing (Tchoroev 2002). However, beginning in the late 1990s a number of studies began to be published highlighting the importance of home gardens in different republics of the former Soviet Union (FSU) for household income generation, subsistence, ability to weather external shocks (such as the collapse of the FSU) and also their importance to the national economies of former Soviet republics (Van Atta 1998, Seeth et al. 1998, Pallot \& Nefedova 2003, Wegren 2004, Lerman \& Stanchin 2004, Lerman 2006, Lerman 2008, Sharashkin 2008). For example, during Soviet times, home garden production in the Soviet Union accounted for only $3 \%$ of the agricultural land area but approximately $30 \%$ of the total gross agricultural product (Lerman et al. 1994). By 2005, Russian home gardens accounted for over $50 \%$ of the total agricultural output (and value) on only $3 \%$ of the agricultural land (Sharashkin 2008). From 1997 to 2007, approximately $60 \%$ of Uzbekistan's agricultural output consistently came from home gardens (Lerman 2008). Home gardens in the FSU continue to be very important for household income generation. Lerman and Stanchin (2004) found that 36\% of income for rural households came from their 0.25 ha. home gardens and in 1997 Ukraine, rural families obtained 53\% of their family income from home gardens. The biophysical, economic and socio-cultural factors that led to the establishment and the current role of home gardens in Kyrgyz household food procurement and income generation is poorly understood. A serious gap 
in home garden research in Kyrgyzstan and from the FSU is the lack of direct research to document how and why cultivated plant species are planted, selected and maintained in, or removed from, gardens. The above-mentioned studies pertaining to household plots are more policy oriented and rely on government statistics or socio-economic surveys that do not address species or varietal composition of home gardens; the focus is not on the home garden, per se, but rather on the role of the home garden in transitional economies. None of the studies examine home garden management strategies, species selection, or species composition in the gardens.

The lack of specificity in these studies relating to home gardens is not surprising as home gardens, in general, are poorly studied (Nair 2001), especially in temperate regions. However, the direct link between economic returns of certain crops and the availability of markets for plant products with species selection by home gardeners has been established by researchers in other agroecosystems (Nautiyal et al. 1998, High and Shackleton 2000). This is likely impacting the diversity of home gardens in the FSU as home gardeners seek to sell more of their home garden production for income generation (Seeth et al. 1998). Decreases in the biodiversity of home gardens due to changes in social relations and the loss of traditional ecological knowledge have also been documented (Cleveland et al. 1994, Agelet et al. 2000). These variables affecting biodiversity and ecological processes within home gardens of the FSU are poorly researched but may not impact agrobiodiversity in the same way due to the unique socio-political-ecological systems in many republics of the FSU. While many researchers are concerned about the loss of 
knowledge about plants and shifts away from agrarian lifestyles (Reedy et al. 2009), in Kyrgyzstan, there was a shift away from nomadic pastoralism towards agrarianism.

Kyrgyz and the History of Home Gardens

Ethnic Kyrgyz have historically been nomadic pastoralists, meaning that they specialize in animal herding that requires movement for grazing (Crawford and Leonard 2002). Kyrgyz pastoralism is primarily of the Eurasian Steppe Type characterized by the herding of horses sheep, goats, cattle and camels (Barfield 1993). While the Kyrgyz and other nomadic pastoralists were never fully self-sufficient and relied on their sedentary neighbors for some of their food and material culture, they only occasionally practiced agriculture and, in general, do not have a strong agricultural tradition (Bacon 1966, Khazanov 2001). There is some evidence that Kyrgyz practiced a combination of pastoralism and agriculture and shifted to a more nomadic herding around 5 B.C. (Kuehnast and Strouthes 1991). After catastrophic livestock losses, Kyrgyz, like neighboring Kazakhs, have been known to focus on agricultural production either as laborers or independently, though often with the goal of returning to pastoralism (Bacon $1966,1954)$.

In the 1800s, Kyrgyz and Russian contact intensified and was relatively peaceful until the 1916 revolt which was precipitated by a number of factors that remain under debate (Kuehnast and Strouthes 1991, Bacon 1966, Tchoroev 2002). One of the results of this revolt was the migration of $1 / 3$ of the Kyrgyz population, primarily to China (Kuehnast and Strouthes 1991, Bacon 1966) along with many of the early Russian settlers who came 
to what is now the Kyrgyz Republic and established many of the home gardens with plant material they brought with them (Currey, unpublished oral history). Kyrgyzstan was designated as a Soviet Autonomous Republic in 1926 and was subject to Stalin's collectivization plans (Kuehnast and Strouthes 1991). The process of collectivization was an important factor in the development of today's Kyrgyzstan for a number of reasons that include: attempted conversion of the Kyrgyz from pastoralists to sedentary agriculturalists, a change in the economy; and disruption of kin networks, and the establishment of household plots, or home gardens (Lerman et al. 1994).

Analyses of available government statistics from 2003-2007 on agricultural production showed that home garden production is very important for the Kyrgyz economy. As of 2007, there were 726,632 home gardens in Kyrgyzstan (NSC 2008) and they averaged 0.1 ha. in size. These home gardens provided $27 \%$ of the total market value of agricultural production in 2007, or $\$ 356.6$ million (2007 1 USD=37.37 Kyrgyz som) on only $9 \%$ of the country's arable land (NSC 2008). Home gardens provided $77 \%$ of the total fruit and berry production in $2007,40 \%$ of the grape and $7 \%$ of the melon production. Additionally, home gardens yielded 52\% of Kyrgyzstan's vegetable production (by value), $28 \%$ of potatoes, and $9 \%$ of grains (NSC 2008). Home garden production has been fairly stable from 2003-2007, with the exception of fruit and berry production and melon production (NSC 2006, NSC 2008). Fruit and berry production has steadily increased from $60 \%$ of the total market value in 2003 to $77 \%$ in 2007 and melon production was stable at around $30 \%$ until 2007 when it fell to $7 \%$, primarily to the result of late frosts that year. For the years in which the questionnaire was 
administered, 2003-2004, households' were asked about their 2003 production. In 2003, home garden production accounted for $22 \%$ of the total value of agricultural output in the Kyrgyz Republic. Home gardens provided $60 \%$ of the value of fruit and berry production, $32 \%$ of the melons, $32 \%$ of the grapes, $52 \%$ of Kyrgyzstan's vegetable production (by value), 29\% of the potato production, and 9\% of the grains (NSC 2006).

In this paper, I examine cultivated plant species diversity in home gardens of two adjacent villages in northeastern Kyrgyzstan. Using an ethnoecological approach (Nazarea 1999) I seek to determine: (1) the status of agrobiodiversity in home gardens and begin to describe the decision-making environment for selected households; (2) the effectiveness and accuracy of different methods for determining cultivated plant diversity in the socio-cultural-ecological context of Kyrgyz households focusing on fruit tree species diversity, singled out because of the predominance of their wild progenitors in Kyrgyzstan; and (3) what factors accounted for observed fruit species diversity, including plant exchange, in an applied ethnobotany context to help elucidate the role of home gardens for agrobiodiveristy conservation.

\section{Study Area}

Fieldwork was conducted in the villages of Tosor $\left(42^{\circ} 09^{\prime} \mathrm{N}, 77^{\circ} 26^{\prime} \mathrm{E}\right.$, approximately 1623 m elevation) and Tamga $\left(42^{\circ} 08^{\prime} \mathrm{N}, 77^{\circ} 32^{\prime} \mathrm{E}\right.$, approximately $1675 \mathrm{~m}$ elevation), Jeti-Oguz Rayon (district), Issyk-Kul Oblast (state), Kyrgyz Republic, beginning in June 2003November 2006. The two villages are $12 \mathrm{~km}$ apart on the shore of Lake Issyk-kul [(1608 m shoreline) in Ter-Ghazaryan \& Heinen 2006, ECONET 2008)]. The Issyk-kul Basin is 
part of the Tien Shan mountain range with elevations that reach $3500 \mathrm{~m}$ (Ter-Ghazaryan \& Heinen 2006; ECONET 2008). The villages are part of the Issyk-kul UNESCO Man and Biosphere Reserve. For more information on the non-agricultural ecosystems of the region, see Krever et al. (1998) and Carpenter et al. (2001).

In 2003 in Tosor, the majority of households were ethnic Kyrgyz and there were 2107 residents, 346 home gardens (totaling 104 ha.) averaging 0.3 ha. with 19.5 ha. of established orchards and 64.0 ha. of newly planted orchards surrounding the village (Jailov 2006). Tamga, in 2006, had more residents (3199) and home gardens, 846 totaling $\sim 85$ ha., but they were smaller in size, at 0.10 ha., and managed by a mixture of ethnic Kyrgyz, Russians, and Tatars: 52.2 ha. of established orchards and 33.0 ha. of newly planted orchards (Jailov 2006). The history of home garden establishment in the two villages differs and the following synopsis of establishment is based on oral histories of current residents. Prior to Russian contact in the late 1890s, ancestors of current Tosor and Tamga residents lived, primarily in the valleys above what is now Tamga, which were the winter settlements for these nomadic pastoralists. Residents report that Slavic serfs that were freed under reforms of the late $19^{\text {th }}$ Century (see Sharashkin 2008) first came to what is now Tamga in the late 1890s. They planted the first gardens, including fruit trees, with plant materials that they brought with them. About the same time, the first fruit tree nursery was established by Russians, some $200 \mathrm{~km}$ away on the north shore of the lake, and Tamga residents obtained seedlings from this nursery. After the 1916 revolt, many of the early Russian settlers left Tamga and Tatar families migrated in with their own plant material at the same time that ethnic Kyrgyz families began to move into 
what is currently Tamga from the valley above (some say there was a delay of around five years before Kyrgyz moved into current Tamga - 1920-1925); one of these Russianestablished Tatar gardens and gardens of two descendants of the first Kyrgyz family were studied in the current research. In the 1920/30s "shepherds" living in the valley above were collectivized and the village of Tosor was established, about $12 \mathrm{~km}$ east of Tamga. However, gardens were not established in Tosor until the 1960s with planting material obtained from the nursery on the other side of the lake and from relatives in Tamga who had already established their gardens. When asked about the time gap between village and garden establishment, one resident said, "Tosor's people were shepherds, not gardeners." Additional gardens in Tamga were planted after World War I in the 1930s as Japanese prisoners of war built a "sanatorium," or recuperation hospital for the Soviet Army, that employed ethnic Kyrgyz, and again in the 1950s and 1960s as in Tosor. The next wave of home garden establishment was in the 70s and 80 s as the garden establishers' children married and started their own families. In Kyrgyz families, traditionally the youngest son inherits the parents' assets, historically livestock, now livestock, homes, home gardens and additional land in private ownership.

\section{Methods}

Data were collected using multiple quantitative and qualitative methods. In 2003-2004 a structured survey with informed consent was undertaken with the heads of households using a random sampled stratified by village in both Tosor $(\mathrm{N}=10)$ and Tamga $(\mathrm{N}=11)$. All households had home gardens. The questionnaire included questions about household composition, land holdings, agricultural production from all land holdings, 
livestock ownership, perceptions of ecological issues affecting home garden production and diversity, use of inputs, information concerning markets for home garden production, sources of income and categorization of expenditures as well as detailed information about home garden composition. Respondents were asked to list the species and varieties of fruit trees and shrubs and vegetables that they grow in their home gardens, the numbers or area planted in each, average age of trees, source of plant material, yields and yields sold.

Gardens were later mapped (2004-2006) with the participation of household members. These maps included the location of all trees and shrubs (fruits, nuts, hedges, living fences, decorative; $\mathrm{N}=20)$ and vegetables, medicinal, and decorative plants $(\mathrm{N}=10)$. The purpose of this mapping was to obtain a full inventory of edible species in home gardens in the study area but also to compare home garden diversity as reported by households in an interview context, a garden walk with full inventorization, and full identification of apple varieties to understand their classification system in the context of in situ agrobiodiversity conservation. The differences in reported diversity and actual diversity of cultivated plants were tested using paired t-tests (total diversity; fruit and nut species diversity; vegetable diversity).

To investigate how the diversity of cultivated fruit species are related to different household characteristics, cultural, and socio-economic factors and to make this study comparable with published research (Coomes and Ban 2004, Perrault-Archambault and Coomes 2008, Aguilar-Støen et al. 2009), I used stepwise multiple-regression analyses 
with backward selection after testing for correlations among the variables (probability $=0.15$ ). The first set of regression models examined species diversity of cultivated fruits (reported and identified), age of the garden, home garden area, number of plots owned in addition to home gardens, importance of agriculture to total household income, proportion of plant species sold, and proportion of plant species received from relatives, neighbors and self-propagation. Anticipating that there would be differences between reported species diversity and actual diversity, I sought to determine if explanatory models for cultivated species diversity yielded different results. I used fruit species diversity as the test variable because of the importance of fruit tree production to household income and the Kyrgyz economy, but also the potential role of home gardens in conserving fruit tree diversity given the high diversity of fruit tree crop wild relatives in Kyrgyzstan. The variables of proportion of plant species sold and proportion of species received and self-propagated were used, rather than the total number of species, due to the differences in the number of species reported by households versus what they actually maintained in their gardens. I tested for outliers in the response variables and removed those that were greater than or less than 3.0 standard deviations from the mean. In an effort to avoid multicollinearity in regression models, independent variables were tested for independence (Barlett Chi-square test statistic).

The second model concerned mapped edible fruit species diversity in home gardens and households' perceptions of environmental issues in their home gardens: soil fertility, soil salinization, light, pest insects, and pollination (bivariate variables: $0=$ not a problem, $1=$ problem for my home garden production). Environmental perceptions were modeled 
with the independent variable of mapped fruit diversity to determine which environmental issues, as perceived by the respondents, may limit or enhance diversity. For the final model, I used an analysis of variance (ANOVA) model and examined mapped cultivated species diversity of fruits (versus reported) as the response variable and the following groups: 1) respondents' who stated they felt having more species in their home garden was more important than, 2) those who said cultivating fewer species but planting a larger for each was more important for them.

Statistical analyses were performed with SYSTAT v. 12. All variables were tested for normality and transformed when necessary, regression models were tested for normality and means are reported \pm one standard error.

\section{Results}

\section{Characteristics of Households}

Surveyed households were predominately headed by men (66\%), with an average age of 51.5 years, who had graduated from high school (11 years) with some higher education and $85.7 \%( \pm 7.8)$ were living in the same villages in which their fathers lived (Table 1). A sizeable portion of households were comprised of more than one generation (38\%). The majority of heads of households were formally employed (57.1 $\pm 11.1 \%)$. Those who are employed cited their occupation as sales and services, teaching, day labor, driving, and other skilled labor. Respondents were asked to identify which member of the family was primarily responsible for their home garden; $62 \%$ were male, much younger than the head of the households with an average age of 42.0 years, and were well 
educated but lacking formal employment (Table 1). Gender of the home gardener was significantly correlated with the ethnicity of the home gardener, with women being more likely to tend the garden in non-Kyrgyz households $\left(\right.$ Pearson $r^{2}=0.693$; Bartlett $X^{2}=$ $12.125 ; \mathrm{p}<0.001)$.

\section{Home Garden Characteristics}

All respondents had home gardens with an average of $34.1 \pm 4.14$ years that ranged in size from 0.17-0.30 ha. (Table 2) and owned at least one other plot, most of which were irrigated (average $1.5 \pm 0.17$ ha. in size, $\mathrm{N}=17)$. They also own small orchards $(0.09 \pm$ 0.04 ha., $\mathrm{N}=12$ ) that were part of collective farms before the collapse of the Soviet Union (Table 1).

Homes and gardens were frequently inherited $(38.1 \% \pm 10.9)$. Home garden boundaries are clearly defined by fencing it came in three types with most households using a combination of all three: living fences $(70 \% \pm 11$; e.g., Salix, Populus, Ulmus, Armeniaca vulgaris), often with barbed wire; metal fencing, both formal and informal (scrap bound

together); or adobe. Homes, livestock shelters and boundary walls are almost exclusively constructed with adobe and provide excellent nesting sites for pollinators such as solitary and social bees. Livestock and poultry roam freely within the home garden but larger animals are generally contained in a fenced area or a shelter within the boundaries of the home garden and, during the day, graze the areas surrounding the villages with a member of the family or with a shepherd (Table 3). When households had animals, manure was 
used in the garden and chemical input use was low, primarily due to the expense and lack of market access (Table 4).

Medicinal and decorative plants were cultivated in gardens in addition to edible plants (Table 5) and living fences. The five most common medicinal plants were Calendula, Matricaria, Melissa, Mentha, and Urtica. The five most common decorative plants grown in home gardens were Dianthus, Gladiolus, Lilium, Chrysanthemum, and Paeonia were grown in home gardens. Home gardens in Kyrgyzstan were multicropped with nearly every household practicing intercropping, sequential, relay, patchwork, and multistory cropping to greater or lesser degrees.

Ninety-five percent of households reported selling production from their home gardens (Table 5). Sixty-five percent of households sold their production from home either to buyers who came to them or to tourists and neighbors. Formal markets are far away from the villages of Tosor and Tamga but $42 \%$ of households sell at market; the average distance to market was $70.6 \mathrm{~km}$ (Table 5). On average, households sell at one market 1.3 \pm 0.80 (range $0-4$ ), and $27 \%$ of households stated that they had difficulties with transporting their production to market (Table 5). Of those that noted the type of transport they used to get their products to buyers, both to formal markets and/or to buyers who came to the villages ( $\mathrm{N}=19)$ : $42 \%$ walked, $26 \%$ used a cart (mostly donkey or horse drawn), $21 \%$ transported by car and $5 \%$ used a bus. The remaining $6 \%$ sold only to buyers who came to them, requiring no transportation. 
One hundred percent of households earned income from agriculture (including home gardens) and for $43 \%$ agriculture was the largest source of income (Table 1). Livestock provided income for $86 \%$ of respondents and for $19 \%$ earnings from livestock was the largest source of income. Salaries provided nearly $24 \%$ of households with their largest income source. Overwhelmingly, households reported food costs ( $29 \%$ of respondents) and educational and medical expenditures (also 29\%) as their largest expenditures. For other households (14\%), agricultural expenditures were their largest expense and coal/firewood expenses were the largest burden for an additional $11 \%$ of households. The remaining four families reported one of the following as their largest household expense: electricity, fuel, business expenses (including taxes, land rent, etc.) or unexpected events such as weddings and funerals.

\section{Edible Plant Diversity}

Respondents reported 23 edible plant species with an average of $11.9 \pm 1.30$ species per home garden (range 3 - 21, N = 20) ("Reported," Table 5; Appendix 2). Fifteen fruit and nut trees, fruiting shrubs, vines and herbaceous fruit species were reported with an average of $6.4 \pm 0.63(3-13, \mathrm{~N}=21)$ per garden. There were a total of 17 different vegetables, with an average of $5.5 \pm 0.73(1-11, \mathrm{~N}=20)$ species reported in home gardens. The three most common species were garlic, potato and carrot (Appendix 2). Households do not sell all species and varieties of fruits and vegetables. On average only three fruit tree species were sold, primarily apple, apricot, and pear (Table 5). Vegetables grown in home gardens are primarily for home consumption with only $0.6 \pm 0.22$ mean species sold. 
Household members identified $(\mathrm{N}=10) 52$ edible plant species (mean $23.9 \pm 2.40$, range $18-43, \mathrm{~N}=10$ ) per home garden (“mapped," Table 5; Appendix 2). This was double the number of cultivated plant species reported by households when interviewed. There were a total of 30 vegetable species $(12.6 \pm 1.42,9-23, \mathrm{~N}=10)$ actually being grown in home gardens. For fruit species $(\mathrm{N}=20)$, home gardens contained from four to 20 species $(9.0 \pm$ 0.83 ). On average, household members reported 8.2 fewer species than they actually grew in their gardens as determined by mapping their gardens (Paired $t$-test; $t_{9}=9.683 ; p$ $<0.001$; In transformed mapped species diversity). The same trend was apparent with vegetable species with respondents reporting 4.7 fewer species than they identified when in their gardens (Paired t-test; $\mathrm{t}_{9}=7.540 ; \mathrm{p}<0.001 ; \ln$ transformed mapped diversity). Household members $(\mathrm{N}=20)$ reported only $6.3 \pm 0.64$ fruit species but actually maintained significantly more species in their gardens $(9.0 \pm 0.83)\left(\right.$ Paired $t$-test; $\mathrm{t}_{19}=$ $6.282 ; \mathrm{p}<0.001)$.

Edible plant species in home gardens are obtained from markets $(58.7 \% \pm 6.7)$ but also received by households $(28.2 \% \pm 5.6)$ from relatives $(54.0 \% \pm 4.1)$ and neighbors $(13.8 \%$ $\pm 5.3)$ (Table 6). On average, respondents $(\mathrm{N}=20)$ reported that they purchased $3.9 \pm$ 0.40 species from markets. While the proportion of species received is similar for fruits and vegetables, households save and plant more of their own species, self-maintained through grafting or seed saving, of vegetables $(24.6 \% \pm 8.4)$ than fruits $(2.3 \% \pm 1.6)$. Thus, only $33.0 \% \pm 8.8$ of the fruit species maintained by households in their gardens $(2.6 \pm 0.70)$ were received through exchange or self-propagation. 
One household was an extreme outlier for mapped edible species diversity and was excluded from the regression models seeking to explain edible fruit species cultivated in gardens as reported by households and mapped diversity. This was the garden of one of the original Tatar settlers of the village of Tamga and with 20 fruit species, diversity in their garden was nearly twice as high as the next most diverse household (12 species) and essentially represents the possible species pool rather than the norm for the communities. The variables of home garden area, age of the home garden, number of additional plots owned, importance of agriculture to total household income, proportion of plant species sold, and proportion of plant species received from relatives, neighbors and selfpropagation were not significantly correlated (Bartlett $\left.\mathrm{X}^{2}{ }_{15}=24.40 ; \mathrm{p}=0.059\right)$. The final model for reported fruit species diversity included the variables of the proportion of species that were received and self-propagated, the proportion of plants sold and the number of plots cultivated in addition to the home garden (Table 7). These factors explained $76 \%$ of the variation in cultivated plant diversity in home gardens $\left(\mathrm{R}^{2}=0.757\right.$, $\left.\mathrm{F}_{4,15}=11.682 ; \mathrm{p}<0.001\right)$. The diversity of cultivated plants was positively related to the proportion of species received and self propagated (more diverse when receive and maintain own) and negatively related to the proportion of species sold, plots cultivated and age of the garden (diversity was lower in older gardens, when households formally sold home garden production and grew crops on additional plots).

When each of the factors that were included in the model were modeled separately using simple linear regression analyses, the proportion of species received and self-propagated significantly explained $31 \%\left(\mathrm{r}^{2}=0.309, \mathrm{~F}_{1,18}=8.053 ; \mathrm{p}=0.011 ; \mathrm{y}=4.915+3.504 \mathrm{x} ; t=\right.$ 
2.838) of the variation in cultivated plant diversity; the proportion of species sold also explained $31 \%\left(\mathrm{r}^{2}=0.305, \mathrm{~F}_{1,18}=7.904 ; \mathrm{p}=0.012 ; \mathrm{y}=8.529-4.468 \mathrm{x} ; t=-2.811\right)$; and the number of plots cultivated explained $20 \%\left(\mathrm{r}^{2}=0.200, \mathrm{~F}_{1,18}=4.510 ; \mathrm{p}=0.048 ; \mathrm{y}=\right.$ $8.080-1.278 \mathrm{x} ; t=-2.124)$. The age of the home garden did not significantly explain reported species diversity. For mapped diversity of edible fruits, nuts, berries and other fruits (e.g., grape and strawberry), the final model differed and included the proportion of fruit/nut species received and self-propagated, the number of plots cultivated, but also home garden area and agriculture as the largest source of income; these variables explained $74 \%$ of the actual variation in fruit/nut species diversity in home gardens $\left(\mathrm{R}^{2}=\right.$ $\left.0.736, F_{4,14}=9.782 \mathrm{p}=0.001\right)($ Table 7$)$. When modeled separately, the proportion of fruit/nut species received and self-propagated was positively related to and explained $28 \%\left(\mathrm{r}^{2}=0.279, \mathrm{~F}_{1,17}=6.575 ; \mathrm{p}=0.020 ; \mathrm{y}=7.226+3.578 \mathrm{x} ; t=2.564\right)$ and, like the model for reported diversity, the number of plots was negatively related to and significantly explained $36 \%\left(\mathrm{r}^{2}=0.359, \mathrm{~F}_{1,17}=9.540 ; \mathrm{p}=0.007 ; \mathrm{y}=11.132-1.811 \mathrm{x} ; t=\right.$ -3.089) of the variation in mapped fruit diversity. Income from agriculture and home garden area did not significantly explain mapped diversity when modeled separately.

Because of multicollinearity, the ethnicity and gender of the home gardener were not included in the regression models, even though it was hypothesized that they would be important explanatory variables. As reported above, gender of the home gardener is significantly correlated with ethnicity, thus the affects of ethnicity and gender on mapped fruit species diversity were tested in separate analyses of variance models. For ethnicity, the two groups were: (1) ethnic Kyrgyz and (2) non-Kyrgyz (Russian, Tatar, Bashkir). 
Home gardens of ethnic-Kyrgyz $(\mathrm{N}=13)$ were significantly less species diverse than those of the Russian $(\mathrm{N}=5)$, Tatar and Bashkir gardens $(\mathrm{N}=1$ for both) and ethnicity explained $52 \%$ of the variation in total species richness $\left(\mathrm{r}^{2}=0.517, \mathrm{~F}_{1,18}=6.583 ; \mathrm{p}=0.019\right)$.

Gardens primarily tended by women were significantly more species diverse than those tended by men $\left(\mathrm{r}^{2}=0.531, \mathrm{~F}_{1,18}=7.050 ; \mathrm{p}=0.016\right)$.

Perceptions of Environmental Problems and Diversity

When respondents were asked their opinion if soil fertility, soil salinization, light, water, pests, inadequate pollination or other issues were limiting yields in their home gardens, $100 \%$ of households stated they had problems with pests and $80 \%$ cited soil fertility as a problem for them (Table 4). Soil fertility was identified as the biggest problem by $19.1 \%$ of respondents and pests were the biggest problem for $33.3 \%$ of respondents. The next most frequently problems reported by respondents were soil salinization and low light (14.3\% of households for both) followed by water availability $(9.5 \%)$. While $29 \%( \pm 10)$ of household members reported problems with pollination, no household identified it as their most serious problem. Additionally, household members were asked about certain management practices. Most use manure (90\%) and do not use chemical fertilizers (75\%) or herbicides $(90 \%)$. No one reported using pesticides in the previous twelve months. Agronomic services were available and were used by $40 \%$ of households, while veterinary services were used by $95 \%$ of households (Table 4 ).

In the regression model seeking to understand mapped edible fruit species diversity as related to respondents' perceptions of environmental challenges in their gardens, the final 
model included the environmental issues, as perceived by respondents, of soil fertility, soil salinization and pollination. These three variables explained $52 \%$ of the variation in mapped fruit tree diversity $\left(\mathrm{R}^{2}=0.524, \mathrm{~F}_{3,15}=5.499 ; \mathrm{p}=0.009\right)($ Table 8$)$. Diversity was negatively related with all variables. When variables were examined in separate simple linear regressions, soil salinization explained $23 \%$ of the variation in plant diversity $\left(\mathrm{r}^{2}=\right.$ $\left.0.226, \mathrm{~F}_{1,18}=5.266 ; \mathrm{p}=0.034 ; \mathrm{y}=9.813-4.313 \mathrm{x} ; t=-2.295\right)$. Soil fertility and pollination problems, separately, did not significantly explain the variation in mapped fruit diversity and since $100 \%$ of respondents reported pest insects were problems for them, this could not be modeled.

\section{Perceptions of Diversity}

Sixty-two percent of respondents stated they felt it was more important to plant small areas of many different species in their garden than it was to plant fewer species in larger areas, thus $62 \%$ of households are prioritizing species diversity (Table 4 ). There was a follow-up question for the attitude of the household towards the importance of diversity in the garden. Though there were slight variations, all households answered this openended question with the same core theme: diversity was needed for nutrition. Household members were specifically asked about changes they made to their garden since the collapse of the FSU. Forty-five percent increased species diversity ( $2 \%$ decreased; remaining made no changes), $47 \%$ increased varietal diversity ( $2 \%$ decreased), $61 \%$ planted more trees ( $1 \%$ have fewer trees than before the collapse) and 34\% have expanded the area of vegetable plantings in their home gardens (3\% decreased) (Table 4). 
The analysis of variance model examining the attitude of heads of households about the importance of diversity and explained reported diversity of fruits was not significant $\left(\mathrm{r}^{2}=\right.$ $\left.0.268, \mathrm{~F}_{1,15}=1.165 ; \mathrm{p}=0.297\right)$.

\section{Discussion}

This research on agrobiodiversity in home gardens in two communities in northeastern Kyrgyzstan has six main results. First, temperate home gardens in Kyrgyzstan are diverse with an average of 24 edible plant species per home garden, more diverse even than some tropical home gardens where researchers reported not only edible species, but all cultivated plants, and, in some cases, full inventories (16 by Coomes \& Ban 2004; 26 by Perrault-Archambault and Coomes 2008; 34 by Kabir and Webb 2009). The total number of edible plant species reported here, 52, is higher than reported in another study that focused on edible plant diversity in Costa Rica (27 in one community, 46 in another by Zaldivar et al. 2002), but much lower than those reported elsewhere that focused on cultivated species diversity ( 82 species by Coomes and Ban 2004), or those that did full garden inventories (e.g., 233 by Aguilar-Støen et al. 2009; 309 by Perrault-Archambault and Coomes 2008). The species diversity of edible plants in Kyrgyz home gardens was expected to be lower than published tropical home garden agrobiodiversity studies, as edible plants are not the only plants maintained in home gardens, and the overall species pool in temperate areas is lower than in the tropics. Sample sizes in this study were small, and as the number of plots sampled increases, one would expect that diversity would also increase. However, one of the gardens randomly selected was one of the original gardens in the whole region and the household has a passion for gardening; they 
are "expert" farmers (Perrault-Archambault and Coomes 2008). Thus, the number of edible species may not significantly increase with a larger sample size, unless in a different eco-region or villages with different ethnic groups known to have quite different dietary preferences and unique gardens (e.g., Dungani, Uzbek). The next step for home garden research in Kyrgyzstan is to begin large-scale studies with full species inventorization in different geographical areas of the country.

Second, it clearly matters what methods are used to determine edible plant species diversity cultivated in home gardens. When interviewed, respondents reported 50\% fewer species of fruit, vegetables, and varieties of apples that they grew in their gardens compared with mapped inventories. There is a distinct pattern to the discrepancies; the less commercial the species, respondents were less likely to report it when interviewed. For example, households did not report wild plums, even though they grew in $14 \%$ of gardens. Perhaps these are not considered by respondents to be "edible," though many use wild plum fruits for jam and alcoholic beverages. Respondents rarely reported the endangered wild apricot (4.8\% respondents reported) even though they were abundant (4.6 \pm 1.4 trees/home garden) and actively cultivated by $62 \%$ of households as living fences and hedges. Nearly all households consume the kernels of and jam made from wild apricots grown in their gardens. Wild apples were not reported by households and only $10 \%$ identified apples as "wild" in their gardens during mapping, not as a separate species, but as an apple variety. But in the process of trying to understand what households meant when they said that their apples "went wild," I found that the rootstock of nearly every "cultivated variety" of apple and apricot in all home gardens was a locally 
collected wild apple or apricot that was planted from seed, in most cases, collected from the valleys above the villages and the cultivated variety later grafted onto to wild species. How deliberate the selection of characteristics of the wild apples for rootstock is (Cleveland et al. 2000), is not known as this phenomenon was not the original target of this research, but it is interesting and calls for further research, especially for adaptations to the arid growing conditions of Kyrgyzstan. These are critical findings for in situ agrobiodiversity conservation research in Central Asia because of the predominance of crop wild relatives of fruit species. The research shows that interviews will underestimate cultivated plant diversity by at least $50 \%$ and give the impression that endangered and threatened species of global economic importance are absent from home gardens when they are actually and literally the foundation of the garden.

However, the third finding is that if the goal of the research is to determine what factors influence cultivated plant diversity in home gardens, interviews may be adequate. When reported and mapped, or actual, fruit species diversity were modeled separately with the same set of explanatory variables results were similar to each other, but with uniquely Soviet nuances when compared to studies conducted in home gardens in other regions of the world. Both models explained a large portion of the variation in fruit species diversity: $76 \%$ of reported and $74 \%$ of actual diversity. These results are comparable to or better than published models of species diversity in home gardens that included similar, though not identical, explanatory and response variables in their final models: 80\% (Coomes and Ban 2004), 35\% (Perrault-Archambault \& Coomes 2008) and 24\% (Aguilar-Støen et al. 2009). For both models, the proportion of plant species received 
and self-propagated and the number of plots cultivated significantly explained the variation in species diversity (reported and actual), even when modeled in separate linear regressions. For mapped diversity, two other variables were included in the final model, but, like Kabir and Webb found in home gardens in Bangledesh (2009), they did not significantly explain actual diversity when modeled separately: largest source of income from agriculture and home garden area. For reported diversity, the variable of proportion of fruit species in the garden sold was included in the final model (but not for actual diversity) and significantly explained $31 \%$ of the variation in reported diversity when modeled in a simple linear regression. As mentioned above, this is likely due to the households' being more likely to report the species if they sell it. This should be taken into consideration when determining which methods to use.

The major differences were not between the two different response variables, but in the relationship of explanatory variables to fruit species diversity in Kyrgyzstan compared with similar studies in other regions of the world. These differences are seemingly due to Soviet legacies and may apply to home gardens in other republics of the Former Soveit Union, especially for the variables of home garden size, additional plots owned, and age of the home garden. While the number of additional plots significantly explained variation in mapped fruit species diversity, like other authors have found for species diversity in home gardens (Coomes and Ban 2004, Perrault-Archambault and Coomes 2008), the relationship was inverted with the number of additional plots cultivated negatively related to species diversity. Households use additional land primarily for vegetable (potato), wheat, and hay cultivation, rather than fruit production associated 
with the distance of plots from the home garden, theft of fruits from plots, and restrictions on the planting of perennial crops. The number of plots cultivated being inversely related to edible species diversity contrasts with the above mentioned studies that found that as land holdings increased, species diversity also increased with an underlying influence of wealth, but this is not exclusively applicable to the FSU. Home gardens in Kyrgyzstan were generally established when collectives were established with residents being allocated similar sized plots at more or less the same time so there is uniformity in the allocation of land within communities in Kyrgyzstan. (see reviews for Soviet Union in Lerman et al. 1994 and Sharashkin 2008). Home garden size and the number of plots cultivated in Tosor and Tamga are not as variable as in other parts of the world and are not good wealth indicators. Home garden age, for reasons mentioned above, also did not explain cultivated plant diversity in this study, though an important factor in other areas of the world (Coomes and Ban 2004, Perrault-Archambault and Coomes 2008, AguilarStøen et al. 2009). However, there were a number of similarities in factors explaining fruit species diversity in Kyrgyzstan with these studies in Peru and Costa Rica. Like these studies, gender and ethnicity of the home gardener, not always the head of the household, was important and gardens were more diverse in households when the home gardener was a non-Kyrgyz woman.

Forth, plant material received from others (relatives and neighbors, alike) is an important factor for the diversity status of gardens in Kyrgyzstan, as in other regions of the world (Vogl-Lukasser et al. 2002, Coomes and Ban 2004, Perrault-Archambault and Coomes 2008, Aguilar-Støen et al. 2009). Home gardeners in the study villages access planting 
material from the wild (especially for fruit tree rootstocks and Ribes spp.), from relatives as they inherit their parents' gardens and are gifted cuttings for grafting and seeds, from neighbors, in situ inheritance from previous landowners when buying land, and from markets (bazaars, nurseries). Plant material exchange is structured and interconnected through plant exchange networks that are kin based (Coomes and Ban 2004, AguilarStøen et al. 2009). Given that non-Kyrgyz gardens with women as the home gardener were more diverse, it is likely that exchange networks in Kyrgyzstan are also, if not kin based, based on ethnic groups and, perhaps distinctly gendered (Aguilar-Støen et al. 2009). "Non-Kyrgyz" in these villages refers to ethnic Russians, Tatars and one Bashkir family. Russian and Tatar families were the first to establish gardens in these villages with material that their descendants say they mostly brought with them. While descendents report that that Tatar families helped Kyrgyz families establish gardens when Kyrgyz moved into what is now the village of Tamga from the valley above, the degree of plant exchange is unknown. Further research is needed to determine plant exchange and understand plant exchange networks.

Fifth, perceptions of environmental issues are important explanatory factors for fruit species diversity in home gardens. Fifty-two percent of the variation in mapped fruit species diversity was explained by households' reporting of problems with soil fertility, soil salinization, and pollination. All households reported problems with pest insects so it could not be modeled. The results contrast somewhat with Corselius and co-authors' (2003) who found that farmers who reported productivity impacts of crop disease were more likely to employ management techniques that resulted in increased diversity. Here, 
diversity decreased based on farmer's perceptions of environmental problems, but then diversity, overall, was relatively high, so perhaps ecological challenges in the garden do influence diversity positively. Formal ecological research and more in-depth study of home gardeners' perceptions and management practices is necessary to better understand these dynamics. While $62 \%$ of households reported that diversity was important, this did not significantly explain actual fruit diversity. The lack of correspondence between attitude and behavior was also found by Coreselius and co-authors (2003) in a study seeking to understand Minnesota farmers' perceptions and cropping systems.

Sixth, home gardens in Kyrgyzstan, like in other former Soviet Republics, are not just for subsistence with $95 \%$ of respondents reporting sales of production (Lerman et al., 1994, Seeth et al. 1998, Pallot and Nefedova 2003, Lerman 2006, Lerman 2008). Researchers from Wisconsin (Corselius et al. 2003) to Bangledesh (Kabir and Webb 2009) have found that increased specialization and commercialization often leads to less diverse cropping systems. However, the link between economic returns of certain crops with species selection by home gardeners may not exert as strong of an influence in Kyrgyzstan as has been established by researchers in other agroecosystems (Nautiyal et al. 1998, High and Shackleton 2000). Kyrgyz home gardens are not in any kind of transitional phase between subsistence and commercialization (Kabir and Webb 2009), but rather the socioeconomic-political decision making environment for households then, and now, included both the need for supplemental food production and the option for market selling (see Lerman et al. 1994, Sharashkin 2008). The majority of home garden in Kyrgyzstan were established with dual goals of subsistence and sales, primarily tended by recently settled 
nomadic pastoralists. The link between market pressures and cultivated plant diversity warrants much more intensive research as Kyrgyzstan struggles to develop their agricultural sector while dealing with high rates of household food insecurity (Dhur 2009).

\section{Conclusion}

Home gardens in Kyrgyzstan are living artifacts of Soviet collectivization and Kyrgyz adaptation to sedentarization that currently play an important role in food provision for households, household income, for in situ conservation of agrobiodiversity, and Kyrgyzstan's agricultural economy. Total edible species diversity and average edible species diversity per home garden was higher than expected and is at levels similar to other home garden studies conducted in radically different socio-economic-politicalecological systems with much longer agrarian histories than the recently settled nomadic pastoralists of Kyrgyzstan. Households that receive plants from relatives and neighbors and also self-propagate have higher fruit species diversity, though the reasons for this are not well understood, but may be related to gendered and ethnicity based exchange networks of plant materials and historical legacies of migration, settlement and collectivization. Factors important to explaining home garden diversity in other parts of the world, in many cases, do not seem to apply to or behave differently when applied to Kyrgyz home gardens, and perhaps to home gardens in other republics of the FSU. These include home garden age, home garden area, and access to additional land due to the way in which home gardens were established as part of collectivization and recent land reforms following the collapse of the FSU. It does not appear that home gardeners 
consciously make planting decisions in regard to diversity to improve harvest security, but do consider food and income needs.

Methods for collecting information about species diversity in home gardens need to be carefully considered as households in this research reported $50 \%$ fewer fruit and vegetable species and over $50 \%$ fewer varieties of apples than they actually maintained in their gardens. Commercially important species and varieties were more likely to be reported by households when interviewed. Crop wild relatives, some of which are IUCN listed were rarely reported by households, but were documented when gardens were mapped with households. For apples and apricots, crop wild relatives are collected and seeds planted in home gardens for use as rootstock and households later graft cultivated varieties onto them. How deliberate the selection criteria are, is unknown, but further research into in situ conservation of wild crop relatives via rootstocks promises to be interesting. Ethnoecological study of home gardens in Kyrgyzstan and other republics of the FSU merits further research, especially for in situ conservation of crop wild relatives, planting exchange networks, and ecological studies of cropping systems that can improve food security in the region.

\section{Acknowledgments}

I would like to thank Daria Toguzbaeva, the interviewers and the families of Tosor and Tamga and both Nurjan Eshimov and Jacob Fleming for garden mapping. The Community Business Forum (now Bashat) introduced me to the residents of Tosor and Tamga and I will always be grateful for that. The Agricultural University of the Kyrgyz 
Republic hosted me as part of the Fulbright program and made accommodations for two of their best students to base their theses on our joint work. This research was supported by the United States Environmental Protection Agency (EPA) under the Science to Achieve Results (STAR) Graduate Fellowship Program, Florida International University's Presidential Enhancement, Fulbright Graduate Research Fellowship, the National Geographic Society Conservation Trust (C61-05), and Mercy Corps. This publication is not officially endorsed by EPA and may not reflect the views of the agency. I thank David Lee, William Vickers, Suzanne Koptur, Bradley Bennett, and Mahadev Bhat for improvements to this paper. 


\section{LIST OF REFERENCES}

Agelet, A., Bonet, M.A. and Vallès, J. (2000). Homegardens and their role as a main source of medicinal plants in mountain regions of Catalonia. Economic Botany 54: 295309.

Aguilar-Støen, M., Moe, S.R., and Camargo-Ricalde, S.L. (2009). Home gardens sustain crop diversity and improve farm resilience in Candelaria Loxicha, Oaxaca, Mexico. Human Ecology 37: 55-77.

Alcorn, J.A. (1981). Huastec non-crop resource management: implications for prehistoric rain forest management. Human Ecology 9: 395-417.

Altieri, M.A., Anderson, M.K. and Merrick, L.C. (1987). Peasant agriculture and the conservation of crop and wild plant resources. Conservation Biology 1: 49-58.

Anonymous. (1993). The Travel of Marco Polo: The Complete Yule-Cordier Edition (The unabridged republication). Dover Publishers, Inc. New York.

Bacon, E.E. (1954). Types of pastoral nomadism in Central and Southwest Asia. Southwestern Journal of Anthropology 10: 44-68.

Bacon, E.E. (1966). Central Asians under Russian Rule: A Study in Culture Change. Cornell University Press, Ithaca.

Baijuka, F.P. and de Steenhuijsen Piters, B. (1998). Nutrient balances and their consequences in the banana-based land use systems of Bukoba district, northwest Tanzania. Agriculture, Ecosystems and Environment 71: 147-158.

Barfield, T.J. (1993). The Nomadic Alternative. Prentice Hall, Upper Saddle River.

Brush, S.B., Kesseli, R., Ortega, R., Cisneros, P., Zimmerman, K. and Quiros, C. (1995). Potato diversity in the Andean center of crop domestication. Conservation. Biology 9: 1189-1198.

Carpenter, C., Fet, G. and Fet, V. (2001). Tian Shan foothill arid steppe (PA0818). Terrestrial Ecoregions of the World. http://www.worldwildlife.org/wildworld/profiles/terrestrial/pa/pa0818_full.html Accessed May 22, 2008.

Cleveland, D.A., Soleri, D. and Smith, S. (1994). Do folk crop varieties have a role in sustainable agriculture. BioScience 44: 740-751.

Cleveland, D.A., Soleri, D. and Smith, S. (2000). A biological framework for understanding farmers' plant breeding. Economic Botany 54: 377-394. 
Coomes, O.T. and Ban, N. (2004). Cultivated plant species diversity in home gardens of an Amazonian peasant village in northeastern Peru. Economic Botany 58: 420-434.

Corselius, K.L., Simmons, S.R., and Flora, C.B. (2003). Farmer percpectives on cropping systems diversification in northwestern Minnesota. Agriculture and Human Values 20: 371-383.

Crawford, M.H. and Leonard, W.R. (2002). The biological diversity of herding populations: an introduction, in Leonard, W.R. and Crawford, M.H. (Eds.). Human Biology of Pastoral Populations. Cambridge University Press, Cambridge.

Currey, R.C.D. (2007). Apples in Home Gardens: Southern Shore, Lake Issyk-Kul, Kyrgyz Republic, in English, Kyrgyz, and Russian. MCK 001/07. Mercy Corps, Bishkek, Kyrgyzstan.

Davis, S.D., Heywood, V.H, and Hamilton, A.C. (1994). Centres of plant diversity: A guide and strategy for their conservation. World Wide Fund for Nature (WWF) and IUCN - World Conservation Union, Cambridge, U.K.

Dhur, A. (2009). Update on the food security and nutrition situation in the Kyrgyzstan Republic: Re-analysis of the Kyrgyz Integrated Household Survey $-1^{\text {st }}, 2^{\text {nd }}$, and $3^{\text {rd }}$ quarters of 2008 - National Statistics Committee. Regional Bureau for the Middle East, Central Asia and Eastern Europe (OMC), World Food Programme.

Dzhangaliev, A. D., Salova, T.N. and Turekhanova, P. M. (2003). The wild fruit and nut plants of Kazakhstan. In: Janick, J. (ed), Wild Apple and Fruit Trees of Central Asia, Horticultural Reviews Volume 29. Jonh Wiley \& Sons, Inc., New Jersey.

Eastwood, A., Lazkov, G., and Newton, A. (2009). The Red List of Trees of Central Asia. Fauna and Flora International, Cambridge, UK.

Forsline, P.L., Aldwinckle, H.S., Dickson, E.E., Luby, J.J. and Hokanson, S.C. (2003). Collection, maintenance, characterization, and utilization of wild apples of Central Asia. In: Janick, J. (ed), Wild Apple and Fruit Trees of Central Asia, Horticultural Reviews Volume 29. John Wiley \& Sons, Inc., New Jersey.

Gajaseni, J. and Gajaseni, N. (1999). Ecological rationalities of the traditional homegarden system in the Chao Phraya Basin, Thailand. Agroforestry Systems 46: 3-23.

High, C. and Shackleton, C.M. (2000). The comparative value of wild and domestic plants in home gardens of a South African rural village. Agroforestry Systems 48: 141156. 
Jailov, J. (2006) Informatsiya iz Ayil Okmotu ot 25.07.2006 goda (Information from Local Village Government from 25.07.2006). Tamga Local Village Administration, Tamga, Kyrgyz Republic.

Kabir, M.E. and Webb, E.L. (2009). Household and homegarden characteristics in southwestern Bangladesh. Agroforestry Systems 75: 129-145.

Krever, V., Pereladova, O., Williams, M. and Jungius, H. (1998). Biodiversity conservation in Central Asia: An analaysis of biodiversity and current threats and initial investment portfolio. Wild Fund for Nature (WWF), Moscow. http://www.wwf.ru/resources/publ/book/eng/36 Accessed May 22, 2008.

Khazanov, A.M. (2001). Nomads in the history of the sedentary world, in Khazanov, A.M. and A. Wink (Eds.). Nomads and the Sedentary World. Curzon Press, Richmond.

Kuehnast, K and Strouthes, D. (1991) Kyrgyz, in Friedrich, P. and N. Diamond (Eds.). Encyclopedia of World Cultures Volume VI: Russia and Eurasia/China. G.K. Hall \& Co., Boston.

Kumar, B.M. and Nair, P.K.R. (2004). The enigma of tropical homegardens. Agroforestry Systems 63: 53-62.

Lamont, S.R., Eshbaugh W.H., and Greenberg, A.M.. (1999). Species composition, diversity and use of homegardens among three Amazonian villages. Economic Botany 53: 312-326.

Lerman, Z. (2006). The impact of land reform on rural household incomes in Transcaucasia. Eurasian Geography and Economics 47: 112-123.

Lerman, Z., and Sutton, W.R. (2008). Productivity and efficiency of small and large farms in transition: evidence from Moldova. Post-Soviet Affairs 24: 97-120.

Lerman, Z., and Stanchin, I. (2004). Institutional changes in Turkmenistan's agriculture: impracts on productivity and rural incomes. Eurasian Geography and Economics 45: 6072.

Lerman, Z., Tankhilevich, Ye., Mozhin, K., and Sapova, N. (1994). Self-sustainability of subsidiary household plots: lessons for privatization of agriculture in Former Soviet Socialist Countries. Post-Soviet Geography 35: 526-542.

Levinson, D. (1998). Ethnic Groups Worldwide: A Ready Reference Handbook. Oryx Press, Phoenix.

MEP. (1998). Kyrgyz Republic Biodiversity Strategy and Action Plan. Ministry of Environmental Protection, Bishkek, Kyrgyz Republic. 
Mintz, S.W. and Du Bois, C.M. (2002). The anthropology of food and eating. Annual Review of Anthropology 31: 99-119.

Moldogazieva, K., and M. Spoor. 1997. Human ecology in Kyrygzstan: the Legacy and the dynamics of transition. Working Paper Series No. 239, Institute of Social Studies, The Hague.

Nair, P.K.R. (2001). Do tropical homegardens elude science, or is it the other way around? Agroforestry Systems 53: 239-245.

NSC. (2006). Sel'skoe khozyaistvo Kyrgyzskoy Respubliki 2003-2005 (Agriculture in the Kyrgyz Republic 2003-2005), in Russian. National Statistical Committee of the Kyrgyz Republic, Bishkek.

NSC. (2008). Sel'skoe khozyaistvo Kyrgyzskoy Respubliki 2005-2007 (Agriculture in the Kyrgyz Republic 2005-2007), in Russian. National Statistical Committee of the Kyrgyz Republic, Bishkek.

Nautiyal, S., Maikhuri, R.K., Semwal, R.L., Rao, K.S. and Saxena, K.G. (1998). Agroforestry systems in the rural landscape - a case study in Garhwal Himalaya, India. Agroforestry Systems 41: 151-165.

Nazarea, V.D. (1999). Ethnoecology. University of Arizona Press, Arizona.

Pallot, J., and Nefedova, T. (2003). Geographical differentiation in household plot production in rural Russia. Eurasian Geography and Economics 44: 40-64.

Perrault-Archambault, M. and Coomes, O.T. (2008). Distribution of agrobiodiversity in home gardens along the Corrientes river, Peruvian Amazon. Economic Botany 62(2): $109-126$.

Reedy, D., McClatchey, W.C., Smith, C., Lau, Y.H. and Bridges, K.W. (2009). A mouthful of diversity: knowledge of cider apple cultivars in the United Kingdom and northwest United States. Economic Botany 63(1): 2-15.

Seeth, H.T., Chachnov, S., Surinov, A. and Von Braun, J. (1998). Russian poverty: muddling through economic transition with garden plots. World Development 26: 16111623.

Sharashkin, L. (2008). The socioeconomic and cultural significance of food gardening in the Vladimir region of Russia. Ph.D. Dissertation, University of Missouri, Columbia.

Shrivastava, R.J., and Heinen, J.T. (2005). Migration and home gardens in the Brahmaputra Valley, Assam, India. Journal of Ecological Anthropology 9: 20-34. 
SYSTAT (2007). SYSTAT for Windows. Version No. 12.02.00. SYSTAT Software, Inc.

Tchoroev, T. (2002). Historiography of Post-Soviet Kyrgyzstan. International Journal of Middle Eastern Studies 34: 351-374.

Van Atta, D. (1998). Household budgets in Ukraine: a research report. Post-Soviet Geography and Economics 39: 606-616.

Vogl-Lukasser, B.N., Vogl, C.R. and Bolhàr-Nordenkampf, H. (2002). Homegarden composition on small peasant farms in the alpine regions of Osttirol (Austria) and their role in sustainable rural development, in Stepp, J.R., Wyndham, F.S. and Zarger, R.K. (Eds.). Ethnobiology and Biocultural Diversity: Proceedings of the $7^{\text {th }}$ International Congress of Ethnobiology. University of Georgia Press, Athens.

Wegren, Stephen, K. (2004). Russian peasant farms and household plots in 2003: a research note. Eurasian Geography and Economics 45: 230-239.

Zaldivar, M.E., Rochas, O.J., Castro, E. and Barrantes, R. (2002) Species diversity of edible plants grown in homegardens of Chibchan Ameridians from Costa Rica. Human Ecology 30(3): 301-316. 
Table 1. Characteristics of households and household member who primarily tends the home garden in Tosor and Tamga, northeastern Kyrgyzstan (N=21).

\begin{tabular}{|c|c|c|c|c|}
\hline & Mean & Std. Error & Range & $\begin{array}{l}\text { Largest } \\
\text { Source \% }\end{array}$ \\
\hline Household size & 4.70 & 0.41 & $1-8$ & \\
\hline No. minors & 1.90 & 0.28 & $0-4$ & \\
\hline Multi-generational ( $1=y e s)$ & 0.38 & 0.11 & - & \\
\hline Home village (1=yes) & 0.86 & 0.08 & - & \\
\hline \multicolumn{5}{|l|}{ Head of household } \\
\hline Age (years) & 51.5 & 2.95 & $28-87$ & \\
\hline Gender $(1=$ female $)$ & 0.33 & 0.11 & - & \\
\hline Education (years) & 13.2 & 0.50 & $7-16$ & \\
\hline Employment (1=yes) & 0.48 & 0.03 & - & \\
\hline Ethnicity (1=non-Kyrgyz) & 0.33 & 0.11 & & \\
\hline \multicolumn{5}{|l|}{ Home gardener } \\
\hline Age (years) & 42.0 & 2.48 & $20-65$ & \\
\hline Gender ( $1=$ female $)$ & 0.38 & 0.11 & - & \\
\hline Education (years) & 13.0 & 0.48 & $11-16$ & \\
\hline Employment (1=yes) & 0.44 & 0.03 & - & \\
\hline \multicolumn{5}{|l|}{$\begin{array}{l}\text { Sources of Income } \\
\text { (proportion of households) }\end{array}$} \\
\hline Agriculture & 1.00 & 0.00 & - & 42.9 \\
\hline Salary & 0.43 & 0.11 & - & 23.8 \\
\hline Livestock & 0.86 & 0.08 & - & 19.0 \\
\hline Business & 0.38 & 0.11 & - & 9.5 \\
\hline Pension & 0.43 & 0.11 & - & 4.8 \\
\hline Wage $(\mathrm{N}=20)$ & 0.15 & 0.08 & - & 0.0 \\
\hline Other & 0.05 & 0.05 & - & 0.0 \\
\hline
\end{tabular}


Table 2. Characteristics of households interviewed in Tosor and Tamga, Kyrgyzstan $(\mathrm{N}=21)$.

\begin{tabular}{l|ccc}
\hline & Mean & Std. Error & Range \\
\hline Household size & 4.70 & 0.41 & $1-8$ \\
No. minors (under 18) & 1.90 & 0.28 & $0-4$ \\
Home garden established (years) $(\mathrm{N}=20)$ & 32.5 & 4.02 & $7-92$ \\
Home garden inherited (1=yes) $(\mathrm{N}=20)$ & 0.40 & 0.11 & - \\
Home garden (ha.) & 0.17 & 0.02 & $0.07-0.30$ \\
No. additional plots owned & 1.57 & 0.19 & $0-3$ \\
Irrigated (ha., N=17) & 1.52 & 0.17 & $0.77-3.40$ \\
Non-irrigated (ha., N=2) & 0.65 & 0.05 & $0.60-0.70$ \\
Orchard (ha., N=12) & 0.09 & 0.04 & $0.006-0.50$ \\
Rented irrigated (ha., N=3) & 1.37 & 1.27 & $0.10-3.90$ \\
\hline
\end{tabular}

Table 3. Livestock holdings of households, Tosor and Tamga, Kyrgyzstan ( $\mathrm{N}=21)$.

\begin{tabular}{l|ccc}
\hline & Mean & Std. Error & Range \\
\hline Cows & 2.5 & 0.40 & $0-6$ \\
Horses & 0.6 & 0.19 & $0-3$ \\
Sheep & 8.0 & 1.82 & $0-30$ \\
Goats & 2.4 & 0.71 & $0-10$ \\
Pigs & 0.7 & 0.41 & $0-6$ \\
Poultry & 20.7 & 2.29 & $5-42$ \\
\hline
\end{tabular}


Table 4. Perceptions of environmental issues and management practices in home gardens, Tosor and Tamga, Kyrgyzstan: proportions of households (binary data).

\begin{tabular}{|c|c|c|c|}
\hline & Mean & Std. Error & Most Serious \% \\
\hline Environmental Problems $(\mathrm{N}=21)$ & & & $\mathrm{N}=21$ \\
\hline \multicolumn{4}{|l|}{$(1=$ Problem $)$} \\
\hline Pests & 1.00 & 0.00 & 33.3 \\
\hline Soil fertility & 0.80 & 0.01 & 19.1 \\
\hline Soil salinization & 0.19 & 0.01 & 14.3 \\
\hline Light & 0.33 & 0.11 & 14.3 \\
\hline Water & 0.24 & 0.01 & 9.5 \\
\hline Pollination & 0.29 & 0.10 & 0.00 \\
\hline \multicolumn{4}{|l|}{ Management Practices $(\mathrm{N}=20)$} \\
\hline \multicolumn{4}{|l|}{$(1=$ Use / Practice $)$} \\
\hline Manure & 0.90 & 0.01 & - \\
\hline Chemical Fertilizers & 0.25 & 0.10 & - \\
\hline Pesticides & 0.00 & 0.00 & - \\
\hline Herbicides & 0.10 & 0.10 & - \\
\hline Agronomic services & 0.40 & 0.11 & - \\
\hline Veterinary services & 0.95 & 0.05 & - \\
\hline Rotation & 0.95 & 0.05 & - \\
\hline Prioritize species diversity $(\mathrm{N}=16)$ & 0.62 & 0.13 & - \\
\hline \multirow{2}{*}{\multicolumn{4}{|c|}{$\begin{array}{l}\text { Changes in Garden Post-Soviet } \\
(1=\text { Increased })(\mathrm{N}=20)\end{array}$}} \\
\hline & & & \\
\hline Increased species diversity & 0.45 & 0.11 & - \\
\hline Increased varietal diversity & 0.50 & 0.12 & - \\
\hline Planted more trees & 0.70 & 0.11 & - \\
\hline Planted more area in vegetables & 0.45 & 0.11 & - \\
\hline
\end{tabular}


Table 5. Edible plant diversity, yields and sales as reported by households, and as mapped, in home gardens, Tosor and Tamga, Kyrgyzstan.

\begin{tabular}{l|rrrr}
\hline & N & Mean & Std. Error & \multicolumn{1}{c}{ Range } \\
\hline Plant Species Mapped & 10 & 23.9 & 2.40 & $18-43$ \\
Fruit/Nut species & 20 & 9.0 & 0.83 & $2-20$ \\
Apple Varieties & 20 & 9.7 & 0.95 & $2-20$ \\
Vegetable species & 10 & 12.6 & 1.42 & $9-23$ \\
Plant Species Reported & 20 & 11.9 & 1.30 & $3-21$ \\
Fruit/Nut species & 21 & 6.4 & 0.63 & $2-13$ \\
Species sold & 21 & 3.1 & 0.40 & $0-7$ \\
Fruit/Nut varieties & 21 & 10 & 1.16 & $4-26$ \\
Apple varieties & 21 & 4.1 & 0.44 & $2-8$ \\
Fruit/Nut yield (kg) & 21 & 1929.9 & 357.30 & $145-7718$ \\
Fruit/Nut yield sold (kg) & 21 & 1293.6 & 250.35 & $0-4600$ \\
Vegetable species & 20 & 5.5 & 0.73 & $1-11$ \\
Species sold & 20 & 0.6 & 0.22 & $0-3$ \\
Vegetable varieties & 20 & 6.4 & 1.0 & $1-18$ \\
Vegetable yield (kg) & 20 & 681.7 & 95.6 & $75-2110$ \\
Vegetable yield sold (kg) & 20 & 160.1 & 92.47 & $0-1810$ \\
Sell Home Garden Production (1=yes) & 20 & 0.95 & 0.05 & - \\
Number of Markets & 20 & 1.3 & 0.80 & $0-4$ \\
Home (1=yes) & 20 & 0.65 & 0.11 & - \\
Market (1=yes) & 19 & 0.42 & 0.12 & - \\
Distance to market (km) & 18 & 70.6 & 31.93 & $0-400$ \\
Problems Transporting (1=yes) & 19 & 0.27 & 0.02 & $0-1$ \\
\hline & & & &
\end{tabular}


Table 6. Sources of plant material for fruit and vegetable species in home gardens as reported by households, Tosor and Tamga, Kyrgyzstan.

\begin{tabular}{|c|c|c|c|c|c|c|}
\hline & \multicolumn{4}{|c|}{ Number of Species } & \multicolumn{2}{|c|}{ Proportion } \\
\hline & $\mathrm{N}$ & Mean & SE & Range & Mean & $\mathrm{SE}$ \\
\hline Total Species & 20 & 11.9 & 1.30 & $3-21$ & - & - \\
\hline Market & 20 & 5.8 & 0.72 & $3-14$ & 0.59 & 0.07 \\
\hline Received & 20 & 3.9 & 0.83 & $0-13$ & 0.28 & 0.06 \\
\hline Relatives & 20 & 2.3 & 0.65 & $0-8$ & 0.14 & 0.04 \\
\hline Neighbors & 20 & 1.7 & 0.65 & $1-13$ & 0.14 & 0.05 \\
\hline Own & 20 & 2.2 & 0.8 & $0-10$ & 0.13 & 0.05 \\
\hline Fruit Species & 21 & 11.9 & 1.30 & $3-21$ & - & - \\
\hline Market & 21 & 3.9 & 0.38 & $2-9$ & 0.70 & 0.07 \\
\hline Received & 21 & 2.6 & 0.66 & $0-10$ & 0.33 & 0.08 \\
\hline Relatives & 21 & 1.4 & 0.51 & $0-8$ & 0.18 & 0.07 \\
\hline Neighbors & 21 & 1.1 & 0.42 & $0-8$ & 0.14 & 0.05 \\
\hline Own & 21 & 0.2 & 0.17 & $0-3$ & 0.02 & 0.02 \\
\hline Vegetable Species & 20 & 5.5 & 0.73 & $1-11$ & - & - \\
\hline Market & 20 & 1.9 & 0.52 & $0-8$ & 0.41 & 0.09 \\
\hline Received & 20 & 1.35 & 0.45 & $0-7$ & 0.30 & 0.09 \\
\hline Relatives & 20 & 0.8 & 0.38 & $0-6$ & 0.10 & 0.05 \\
\hline Neighbors & 20 & 0.6 & 0.27 & $0-5$ & 0.20 & 0.08 \\
\hline Own & 20 & 2.1 & 0.77 & $0-10$ & 0.25 & 0.08 \\
\hline
\end{tabular}


Table 7. Regression models of number of edible fruit species in home gardens as reported by households and as mapped in gardens $(\mathrm{N}=20) * * * \mathrm{p}<0.001 ; * * \mathrm{p}<0.01 ; * \mathrm{p}$ $<0.05$.

\begin{tabular}{|c|c|c|}
\hline Variables & $\begin{array}{c}\text { Mapped } \\
\text { Coefficient }(t \text { value })\end{array}$ & $\begin{array}{c}\text { Reported } \\
\text { Coefficient }(t \text { value })\end{array}$ \\
\hline (Constant) & $11.354(10.883)^{* * *}$ & $10.011(8.527)^{* * *}$ \\
\hline $\begin{array}{l}\text { Proportion plant species received } \\
\text { and self-propagated }\end{array}$ & $3.625(3.680)^{* *}$ & $3.210(3.914)^{* * *}$ \\
\hline Proportion plant species sold & - & $-3.942(-3.708)^{* *}$ \\
\hline Number of plots cultivated & $-0.861(-1.824)$ & $-0.817(-2.116)$ \\
\hline Home garden area & $-11.867(-2.287)^{*}$ & - \\
\hline Home garden age & - & $-0.051(-2.165)^{*}$ \\
\hline $\begin{array}{l}\text { Income from agriculture } \\
(1=\text { largest source for household })\end{array}$ & $-2.053(-2.631)^{*}$ & - \\
\hline Model (step-wise) $\mathrm{R}^{2}$ & 0.736 & 0.757 \\
\hline F - ratio & 9.782 & 11.682 \\
\hline$P$ value & 0.001 & $<0.001$ \\
\hline
\end{tabular}

Table 8. Regression models of number of edible fruit species in home gardens as mapped in gardens with respect to environmental issues $(\mathrm{N}=19) * * * \mathrm{p}<0.001$; ** $\mathrm{p}<0.01$; * $\mathrm{p}<$ 0.05 .

\begin{tabular}{l|l}
\hline Variables & $\begin{array}{c}\text { Mapped } \\
\text { Coefficient (t value) }\end{array}$ \\
\hline (Constant) & $14.895(7.996)^{* * *}$ \\
Soil Salinization & $-6.109(-3.543)^{* *}$ \\
Soil Fertility & $-4.382(-2.427)^{*}$ \\
Pollination & $-2.577(-1.719)$ \\
Model (step-wise) $\mathrm{R}^{2}$ & 0.524 \\
F - ratio & 5.499 \\
P value & 0.009 \\
\hline
\end{tabular}




\title{
CHAPTER IV
}

\section{HOME GARDENS CONSERVE HYMENOPTERA DURING APPLE BLOOM,} ISSYK-KUL, KYRGYZ REPUBLIC

\begin{abstract}
Pollination dependent fruit trees play an important role in the agricultural based economy of Kyrgyzstan and other Central Asian countries, yet little is know about the status of pollinator communities. Contributions from Central Asia have been noticeably absent in recent research detecting pollinator declines and pollination limitation in agricultural systems. I surveyed the Hymenoptera in apple and apricot dominated home gardens and orchards in northern Kyrgyzstan over two years, investigating how species richness and abundance of total Hymenoptera, solitary bees, social bees, and wasps was related to overstory cover, overstory bloom, vegetation cover, average ground cover height, and agroecosystem management. Average height of vegetation was the best predictor of Hymenoptera richness and abundance, bee abundance and richness, as well as solitary bee abundance and richness. Vegetative ground cover best predicted wasp abundance and diversity and bumblebee richness and abundance. There were no significant differences in Hymenopteran community composition between home gardens and orchards. The results suggest that organic, high elevation home gardens and orchards of the arid Issyk-Kul region, as currently managed, support abundant and diverse pollinator communities, with few differences in community composition between management types.
\end{abstract}


Key words: Apple, Home garden, Hymenoptera, Kyrgyzstan, Pollinator community, Solitary bees.

\section{Introduction}

Wild pollinators are important for crop pollination, but habitat destruction and land use intensification, especially in agricultural landscapes, can threaten pollinator communities and their ability to provide crop pollination services (Steffan-Dewenter and Westphal 2008). Globally, wild pollinators are in decline for a number of reasons including habitat loss and fragmentation, pesticide use, and disease (Banaszak 1992; Buchmann and Nabhan 1996; Kearns and Inouye 1997; Kevan 1999; Kearns 2001; Goulson 2003; Billeter et al. 2008). However, Steffan-Dewenter and Westphal (2008) noted a gap in pollinator research from subtropical and temperate regions and contrasting results concerning the effects of different agricultural management strategies on pollinator communities and pollination services (Kevan 1999; Winfree et al. 2008). Contributions from Central Asia have been noticeably absent in recent research detecting pollinator declines and pollination limitation, even though the mountains of Central Asia are a global biodiversity hotspot (Davis et al. 1995). Very little is known about the ecology of agriculture in the Kyrgyz Republic and there is a paucity of information concerning insect community composition in Kyrgyzstan, especially in home gardens (Chelpakova and Milko 2004).

Home gardens in the Kyrgyz Republic contribute as much as $50 \%$ of agricultural value added and marketed surplus for the Kyrgyz Republic, and provide households, despite 
their small size (average $0.1 \mathrm{ha}$ ), with a sizable portion of their income (World Bank Kyrgyz Republic 2005). Home gardens are typically described as small-scale agroforestry systems with a mixture of trees, shrubs, herbs and other cultivated crops in the area, surrounding a household maintained and managed by those in the household (Fernandes and Nair 1986). In 2006, fruit and berry production in Kyrgyzstan was over 186,600 tons, with nearly $62 \%$ of that yield being grown in home gardens (National Statistics Committee of the Kyrgyz Republic 2008). Apples from home gardens provided households in the Issyk-Kul region of Kyrgyzstan with nearly $10 \%$ of their annual revenue (Ostashko and Currey 2007). Earning income from the sale of home garden production is not a new trend, and this pattern of production is not unique among countries of the Former Soviet Union (Seeth et al. 1998; Lerman and Stanchin 2004). For example, Seeth and co-authors (1998) found that $90 \%$ of fruit and berries in Russia were grown in home gardens and small private plots, and households in Turkmenistan earned 36\% of their income from home gardens (Lerman and Stanshin 2004).

Although very little is known about the ecology of agriculture in the Kyrgyz Republic, even less is known about the growing conditions in home gardens and the entomofauna of Kyrgyzstan. Kyrgyzstan is an arid and mountainous country with the Pamir and Tien Shan mountains comprising $90 \%$ of the territory with elevations ranging from $132-$ $7,439 \mathrm{~m}$, and, without more detailed information, it seems similar to many counties of the Hindu Kush-Himalayan (HKH) region (Ministry of Environmental Protection, 1998, Eastwood et al., 2009). In many countries of the HKH region, apple is the main cash crop in high-elevation mountain agriculture, providing as much as $60-80 \%$ of total 
household income for small farmers (Partap and Partap 2002). These authors identified inadequate pollination as the major cause of recent declines in apple productivity in the $\mathrm{HKH}$ region, citing declining populations of native pollinators as an important limiting factor to apple yields. Determining the status of pollinator communities is difficult for Kyrgyzstan because of poor entomological knowledge in agroecosystems in the region.

The dominant tree species in home gardens of northern Kyrgyzstan are apple (Malus X domestica Borkh.), apricot (Armeniaca vulgaris Lam.), pear (Pyrus communis L.); shrubs include currant (Ribes spp. L.) and raspberry (Rubus spp. L.) and a variety of vegetables, herbs, and grasses are present in home gardens. Apple cultivars are predominately selfsterile but can also be variably self-fertile or self-fertile (in Pratt 1988). In general, apple flowers must be insect (or hand) pollinated to obtain fruits (McGregor 1976; Partap and Partap 2002). Pollinators of apple flowers are known to include honeybees, bumble bees, solitary bees and some flies (Scott-Dupree and Winston 1987; Kearns 2001; Partap and Partap 2002). In the Kyrgyz Republic, we lack published research on pollinator communities and insect communities in home garden systems (Chelpakova and Milko, 2004). The lack of information on the entomofauna of Kyrgyzstan is an especially notable gap in knowledge, given the number of economically important, insect pollinatordependent agricultural species whose wild relatives are native to the region. Crop wild relatives in Kyrgyzstan include the main progenitor of cultivated apple, M. sieversii (Lebed.) M.Roem.; M. niedzwetzkyana Dieck., another wild relative of the domesticated apple; the wild apricot, Armeniaca vulgaris Lam., the wild pear Pyrus korshinskyi Litv., and the almonds, Amygdalus bucharica Korsh. and A. ledebouriana Schlecht., among 
others (Ministry of Environmental Protection 1998; Dzhangaliev et al. 2003; Forsline et al. 2003; Eastwood et al. 2009; IUCN 2009).

Home gardens, low-intensity agro-forestry plots, and abandoned temperate orchard meadows all tend to have high levels of biodiversity, and are known to be important for the conservation of not only agrobiodiversity (Altieri 2004), but also birds (Mas and Dietsch 2004; Perfecto et al. 2005; Dietsch et al. 2007) and insects (Klein et al. 2003; Perfecto et al. 2003; Steffan-Dewenter 2003; Steffan-Dewenter and Leschke 2003; Armbrecht et al. 2005; Gardener and Ascher 2006; Winfree et al. 2008). The latter reported that orchard meadows in Central Europe are one of the most species rich habitat types and that bees and wasps are good indicator species. Bees are good indicators of floral diversity and wasps of insect and spider diversity (Kevan 1999; Steffan-Dewenter and Leschke 2003).

Given the lack of information about insect communities in Kyrgyzstan, the importance of apple production and home garden yields to livelihoods of the rural poor in Kyrgyzstan, and the disturbing findings of Partap and Partap (2002) documenting declining pollinator populations in high-elevation apple systems, I have attempted to document and describe the fauna of Hymenoptera that inhabit apple and apricot-dominated home gardens and orchards during apple bloom. The objectives of this survey were to document and characterize the diversity and abundance of bee and wasp species during bloom, and then use that information to compare the communities of bees and wasps between home gardens and orchards using different taxonomic and ecological variables and 
categorizations of the hymenoptera fauna and agroecosystems. My goal was to begin documenting the bee and wasp communities in Kyrgyzstan, to detect if potential pollinator populations are limited at the local scale, and to provide management recommendations for apple cultivation for Kyrgyz households.

Methods

Study Area

Data were collected in two villages with two different types of apple management systems: home gardens and orchards in Tosor $\left(42^{\circ} 09^{\prime} \mathrm{N}, 77^{\circ} 26^{\prime} \mathrm{E}\right)$ and Tamga $\left(42^{\circ} 08^{\prime} \mathrm{N}\right.$, 77³2'E), Issyk-kul Oblast, Jeti-Oguz Rayon, Kyrgyz Republic. The two villages are 12 $\mathrm{km}$ apart on the shore of Lake Issyk-kul [(1608 $\mathrm{m}$ shoreline) in Ter-Ghazaryan and Heinen 2006, ECONET 2008)]. The Issyk-kul Basin is part of the Tien Shan mountain range with elevations that reach $3500 \mathrm{~m}$, and it supports nearly $40 \%$ of known insect species in Kyrgyzstan (Chelpakova and Milko 2004; Ter-Ghazaryan and Heinen 2006; ECONET 2008). The villages are part of the Issyk-kul UNESCO Man and Biosphere Reserve. For more information on the non-agricultural ecosystems of the region, see Krever et al. (1998) and Carpenter et al. (2001).

In 2006 in Tosor, the majority of households were ethnic Kyrgyz and there were 346 home gardens (totaling 104 ha.) averaging 0.3 ha. with 19.5 ha. of established orchards and 64.0 ha. of newly planted orchards surrounding the village (Jailov 2006). Tamga, in 2006, had more home gardens, 846 totaling $\sim 85$ ha., but they were smaller in size, at 0.1 ha, and managed by a mixture of ethnic Kyrgyz and Russians: 52.2 ha. of established 
orchards and 33.0 ha. of newly planted orchards (Jailov 2006). In both villages, most home gardens were established in the 1960's and 1970's but some as early as the late 1800s (Currey, unpublished interviews). The older orchards were established at various times, from 1950 to 1988 (Jailov 2006). All plots studied used organic methods.

Orchards were dominated by apple, lacked a shrub layer, and the understory herbs and grasses were mostly unmanaged.

In 2005, I studied bees and wasps in six home gardens and one orchard plot in Tosor. In 2006, I sampled four of the previously selected home gardens and the orchard plot. I added four home gardens and four orchards in Tamga and three orchards in Tosor, for a total of eight home garden plots and eight orchard plots. Locations of plots were determined with GPS (eTrex ${ }^{\circledR}$, Garmon, 2004). Home gardens were selected through a stratified random sample: edge of the village and village interior. The established orchards that were sampled were collectively managed during Soviet times and have since been divided among householders.

\section{Data Collection}

In 2006 for each home garden and orchard, a $100 \mathrm{~m}^{2}$ plot was randomly established at least $2.5 \mathrm{~m}$ from the edge of the garden. This plot was sampled with 30 minute sweep netting intervals with one consistent collector within the $100 \mathrm{~m}^{2}$ plots a minimum of three times during apple bloom (May 2 - May 13). Sweep netting was concentrated around fruit trees, which were in bloom at the times, with particular attention to flower visitors. Temperature, percent relative humidity, and average wind speed during a three minute 
interval were measured at the beginning and end of each sampling period $\left(\right.$ Kestrel $^{\circledR} 3000$ Pocket Weather ${ }^{\mathrm{TM}}$ Meter). Insects were only collected on sunny, partly sunny or bright overcast days with light breezes (wind speeds no greater than $1.6 \mathrm{~m} \mathrm{~s}^{-1}$ ).

In 2005, home gardens were sweep netted three to four times during apple bloom (May 9 - May 25) while the orchard plot was sampled with one hour sampling intervals. As in 2006 , temperature, percent relative humidity, and average wind temperature during a three minute interval were measured at the beginning and end of each sampling period.

All insects were identified to species (with few exceptions) by Dmitry Milko, Department of Entomology, Institute for Biology and Pedology (IBB), National Academy of Sciences, Bishkek, Kyrgyz Republic. Original specimens were deposited mainly in the collection at the Department of Entomology, IBB, with additional specimens in Currey's personal collection.

\section{Vegetation}

All home gardens were of known area and all tree and shrub individuals were completely mapped in 2005 and updated in 2006. Within each garden and orchard, vegetation was mapped once in each plot between May 5 and May 12 in a randomized $100 \mathrm{~m}^{2}$ plot to determine percentage cover of all vegetation and vegetation in flower, number of trees, species of trees, number of stems for each tree and diameter at breast height (dbh), from which basal area was calculated. Within the $100 \mathrm{~m}^{2}$ plot, a $25 \mathrm{~m}^{2}$ subplot was established to estimate the percent cover of vegetation, shrubs, herbs and/or shrubs in flower, litter, 
woody debris, dried manure and bare ground. The mean heights of vegetation and shrubs were also recorded.

\section{Data Analysis}

Insect and vegetation data for each of the 16 sites were pooled for analyses after I equalized the number of samples per site to three by removing three samples with incomplete weather data and randomly reducing samples of the remaining sites (2006). The 2005 data set was used only to document the Hymenoptera of the area, to compare the number of species between years, and to determine the estimated species richness. All additional analyses used 2006 data. Data were tested for normality and transformed when necessary using the following transformations: vegetative ground cover was logit transformed; counts of wasp individuals were lognormal-transformed, $\ln (\mathrm{x}+1)$; counts of bees were square root transformed and counts of wasp species were transformed as square roots $(\mathrm{x}+0.5)$ (Sokal and Rohlf 1995).

\section{Species Richness}

I produced sample-based rarefaction curves of species abundance by richness for years (2005, 2006), villages (2006: Tosor, Tamga), and for each management type (2006: Home Garden, Orchard). Recognizing that observed species in a community is a biased estimate of that species richness of that community, (Colwell and Coddington 1994; Chazdon et al. 1998; Coddington and Colwell 2002; Longino et al. 2002; Armbrecht et al. 2005), I also used the non-parametric incidence-based coverage estimator (ICE) (Colwell and Coddington 1994; Chazdon et al. 1998). These were calculated to 
determine sampling efficiency $\left(\mathrm{S}_{\mathrm{obs}}\right.$ (Mao Tao) / $\mathrm{S}_{\mathrm{est}}(\mathrm{ICE})$ ) (Colwell 2006; Watling and Donnelly 2008) and to characterize the species richness of the area, using estimators due to the small sample sizes in this study and many rare species $(\mathrm{N}=16$; Chazdon et al. 1998). Rarefaction curves and estimators were obtained using Estimate S8.0 (Colwell 2006). I compared sample-based rarefaction curves by visual inspection of $95 \%$ confidence intervals (Colwell et al. 2004). ICE values for years, villages and management type were compared with one-way analysis of variance (ANOVA).

To investigate how the abundance and diversity of different groups of species are related to habitat characteristics, and to make this study comparable with published research (Klein et al. 2003; Steffan-Dewenter and Leschke 2003; Winfree et al. 2008), I used stepwise multiple-regression analyses with backward selection after testing for correlations between the five habitat variables (probability $=0.15$ ): $\%$ overstory cover, $\%$ overstory in flower, $\%$ herbaceous cover, average height of ground cover. The dependent variables, the species groups, are as follows: all Hymenoptera individuals and species; bee individuals and species; solitary bee individuals and species; social bee individuals and species; bumble bee individuals and species; and wasp individuals and species. Like Klein and co-authors (2003), the habitat factor with the best fit in each model is shown in a separate linear regression model with the dependent variable.

\section{Species Composition}

I compared species composition of the wild bee and wasp communities in home gardens and orchards and between localities (villages) using Analysis of Similarity (ANOSIM; 
PAST Program for Windows, Hammer, Harper and Ryan 2001) I used Morisita's index for abundance data to calculate the similarity matrices (distance measure) upon which ANOSIM tests and nMDS plots are based, since it provides a robust way to test community overlap by comparing species abundances between pairs of sites (McIntyre and Hostetler 2001; PAST 2008). Social bees, solitary bees, wasps were analyzed separately. I repeated the same analysis for home gardens and orchards between villages. I also used ANOSIM to determine if home gardens and orchards were compositionally similar with respect to habitat variables. Non-metric multidimensional scaling (nMDS) was used to visually display the results of the ANOSIMs.

Except were otherwise noted, statistical analyses were performed with SYSTAT v. 12. Arithmetic means \pm 1 standard errors of the mean are presented in the text and error bars in graphs.

Results

Vegetation

There were $5.3 \pm 0.4$ fruit trees per $100 \mathrm{~m}^{2}$, but the mean number of fruit trees differed significantly between home gardens and orchards, with $4.4 \pm 0.3$ trees in orchards and 6.4 \pm 0.6 trees squeezed into home gardens (Mann-Whitney $U=9.00, \chi^{2}$ approximation $=$ $6.381 ; \mathrm{p}=0.011 ; \mathrm{df}=1)($ Table 1$)$. However, I found no significant differences between agroecosystem types in total basal area $\left(0.15 \pm 0.02, \mathrm{~F}_{1,14}=2.313 ; \mathrm{p}=0.151 ; \mathrm{n}=16\right)$, overstory cover $\left(47.8 \pm 4.5 \% ; \mathrm{F}_{1,14}=0.877 ; \mathrm{p}=0.365 ; \mathrm{n}=16\right)$ or percentage flower cover in the overstory $\left(21.9 \pm 3.8 \% ; \mathrm{F}_{1,14}=0.949 ; \mathrm{p}=0.346 ; \mathrm{n}=16\right)$ during bloom. 
Apple trees dominated the overstory of orchard plots $(96.9 \pm 3.1 \%)$ but home garden plots had a significantly more diverse overstory $(74.8 \pm 3.6 \%$ ) (Mann-Whitney $\mathrm{U}=54.5$, $\chi^{2}$ approximation $\left.=6.4, \mathrm{p}=0.012, \mathrm{df}=1\right)$. Vegetation cover (herbs and grasses) was quite variable in home gardens $(69.2 \pm 14.8 \%)$ and although much lower than in orchards $(90.8 \pm 2.1 \%)$, the differences were not statistically significant (Mann-Whitney $\mathrm{U}=38.00, \chi^{2}$ approximation $\left.=0.397 ; \mathrm{p}=0.529 ; \mathrm{df}=1\right)$. Overall, there were less than $0.02 \mathrm{~m}^{2}( \pm 0.010)$ of vegetation in flower in the $25 \mathrm{~m}^{2}$ subplots, or less than $0.001 \%$ of the subplot area and no significant differences between home gardens and orchards (MannWhitney $\mathrm{U}=29.50, \chi^{2}$ approximation $\left.=0.071 ; \mathrm{p}=0.789 ; \mathrm{df}=1\right)$. Vegetation height $\mathrm{did}$ not significantly differ between home gardens and orchards $\left(14.2 \pm 3.16 \mathrm{~cm} ; \mathrm{F}_{1,14}=\right.$ $0.030 ; \mathrm{p}=0.866 ; \mathrm{n}=16)$. Overall, agroecosystem composition did not vary between home gardens and orchards (Global $\mathrm{R}=-0.033 ; \mathrm{p}=0.529$ ) or between locality (villages) $($ Global $\mathrm{R}=0.035 ; \mathrm{p}=0.396)$.

Hymenoptera Species Richness and Abundance

I collected 765 Hymenoptera individuals (279 in May 2005, 486 May 2006) belonging to 56 bee and 13 wasp species ( 18 species unique in 2005, 19 in 2006, 31 species common to both years) (Appendix 3). However, after having equalized the number of samples per site and removed samples with missing environmental data, subsequent analyses were based on the following: 652 bees and wasps (171 in May 2005, 481 May 2006) belonging to 53 bee and 13 wasp species ( 16 species unique in 2005, 23 in 2006, 27 species common to both years) (Appendix 3). 
In 2006, the average number of species in orchards was higher than home gardens, as can be seen in rarefaction curves based on both sampling units and number of individual bees and wasps (Fig. 1). The village of Tamga, with its smaller home garden plots and younger orchards, had slightly higher average species richness than Tosor when comparing sample-based rarefaction curves for Hymenoptera fauna (Fig. 1). Average bee and wasp species richness in home gardens was higher in first year of the study than in 2006 (Fig. 1).

The Incidence-based coverage estimator (ICE) (sampling efficiency) value for diversity for the two villages and both apple management systems in 2006 was $80.4 \pm 3.84$ (std. dev.) species. (ICE) mean values (Colwell 2006) for Hymenoptera were statistically different between years for home gardens $\left(\mathrm{F}_{1,12}=12.37 ; \mathrm{p}=0.004 ; 2005=76.83 \pm 6.55\right.$; $2006=51.90 \pm 3.73)$ and marginally different between home gardens $(51.90 \pm 3.73)$ and orchards $(64.89 \pm 5.11)$ in $2006\left(F_{1,14}=4.217 ; p=0.059\right)$. No differences were detected between villages with an overall ICE mean value of $58.80 \pm 3.48)\left(F_{1,14}=0.043 ; p=\right.$ 0.838). Using the non-parametric ICE to estimate sampling efficiency, I found that home gardens in $2006(51.7 \% \pm 5.82)$ had higher sampling efficiency than orchards $(43.3 \% \pm$ 4.34), and overall sampling efficiency averaged $47.5 \% \pm 3.67$.

In step-wise multiple-regression analyses with the habitat variables of percent overstory cover, overstory in flower, herb cover, and average height of vegetation, I tested which were important to bees and wasps. These variables were not significantly correlated with each other (Pearson correlation matrix; Bartlett $\chi_{6}^{2}=6.81 ; p=0.338$ ). Overall abundance 
of Hymenoptera significantly decreased as the average height of ground cover increased (Table 2; Fig. 2). The number of bee individuals also decreased as ground cover vegetation height increased (Fig. 2), but the percentage vegetative ground cover was also important to bee individuals (Table 2). Together, the height of vegetation and percent vegetative ground cover explained $66 \%$ of the variability in the number of bee individuals encountered in home gardens and orchards in the two villages of Tosor and Tamga in Issyk-Kul Oblast (Table 2). When modeled separately, only the height of vegetation explained a significant portion of the variance in the number of bee individuals (Fig. 2). None of the independent habitat variables explained a significant portion of the variance in the number of Hymenoptera species or the number of bee species (Table 2).

The richness and abundance of solitary bees, social bees (A. mellifera and Bombus spp. separately), and wasps were analyzed separately. None of the independent variables explained a significant portion of the variation in social bee abundance, nor the abundance of $A$. mellifera, when analyzed separately (backwards stepwise multipleregression with enter/remove probability $=0.15$ ). However, nearly $47 \%$ of the variability in the number of individuals of social Bombus spp. was significantly explained by the percentage of overstory cover and the percentage of vegetative ground cover (Table 2). The number of solitary bees was affected by a different habitat factor: height of ground cover vegetation (Table 2). The number of solitary bee individuals and also solitary bee species decreased as the height of ground cover vegetation increased and the height of ground cover explained $52 \%$ and $27 \%$, respectively, of the variation in solitary bee 
individuals and species (Table 2; Fig. 3). The number of social bee species was positively correlated with the percentage of ground cover vegetation (Fig. 4). When analyzed separately, it was the number of species of Bombus spp., rather than A. mellifera that were driving this relationship and 33\% of the variation in number of Bombus spp. was explained by the percentage of ground cover vegetation (Table 2; Fig. 4). Unlike the number of Bombus spp. individuals and species, and the number of all bee individuals, the number of wasps and wasp species were both negatively correlated with the percentage of vegetative ground cover and not significantly related to the height of ground cover vegetation. The percentage of vegetative ground cover explained approximately 33\% of both the number of wasp individuals and species (Table 2; Fig. 5). Simple linear regressions showed that only the habitat factors of average ground cover height, percentage of vegetative ground cover, and percentage of overstory cover were significantly related to Hymenoptera abundance and richness (Table 2). The overall number of Hymenopteran individuals (Fig. 2), number of bee individuals (Fig. 2), number of solitary bee individuals and species (Fig. 3) significantly decreased as the height of the ground cover vegetation increased, and these results indicate that social bees and wasps are not related to ground cover height (Table 2). The abundance of wasps significantly decreased as the percentage ground cover increased (Fig. 5), while the number of species of bumblebees significantly increased as the percentage of vegetative ground cover increased (Fig. 4). Only the number of bumble bee individuals was positively related to overstory cover (Fig. 6). Overstory cover explained $30 \%$ of the variability in the number of bumble bees encountered in home gardens and orchards. 


\section{Species Composition}

In 2006, I recorded six species of social bees (Hymenoptera: Apidae; 165 individuals), 34 species of solitary bees (Hymenoptera: Andrenidae, Apidae, Halictidae, Megachilidae; 282 individuals) and 10 species of wasps (Hymenoptera: Chrysididae, Ichneumonidae, Vespidae; 34 individuals) (Appendix 1). Five species accounted for over $55 \%$ of the total individuals collected (in descending order): Apis (s. str.) mellifera L., Anthrophora acervorum L., Andrena (Melandrena) cineraria L., Andrena (Melandrena) limata $\mathrm{F}$. Smith, and Bombus (s. str.) terrestris L. The most numerous species was A. mellifera (20\%) in home gardens and orchards alike. Of the species captured, 27 were represented by only 1 or 2 individuals, with 10 species found in only home gardens and 8 in orchards only (Appendix 1).

Overall, species composition of Hymenoptera fauna did not vary by local land use (home garden/orchard; ANOSIM; Global $\mathrm{R}=0.071, \mathrm{p}=0.167$ ), but composition did vary between villages (ANOSIM; Global $\mathrm{R}=0.359, \mathrm{p}=0.022$ ) (Fig. 7). When examined separately, the community compositions of social bees, and also that of wasps, were found to be similar in both home gardens and orchards (Global $R_{\text {social }}=-0.020, p=0.533$; Global $\mathrm{R}_{\text {wasp }}=0.094, \mathrm{p}=0.086$ ); nor were there differences between localities, or villages $\left(\right.$ Global $R_{\text {social }}=-0.001, p=0.468 ;$ Global $\left.R_{\text {wasp }}=-0.096, p=0.720\right)$. However, the difference in community composition of solitary bees between home gardens and orchards was marginally significant (Global $\mathrm{R}=0.122, \mathrm{p}=0.052$ ), as was the composition between villages (Global $R=0.287, p=0.054$ (Fig. 7). 


\section{Discussion and Conclusions}

In this study, apple tree dominated home gardens and orchards at high elevations in northern Kyrgyzstan were found to support abundant and diverse pollinator communities during apple bloom, with few differences in community composition between the agroecosystem types. My results contrast with Partap and Partap's (2002) detection and documentation of the alarming loss of pollinators and pollinator services in the neighboring Himalayan region in high elevation fruit orchards, although the presence of pollinators does not necessarily mean they are providing pollinator services for fruit trees. Nonetheless, my results show that intensively managed, high elevation home gardens and orchards support abundant and diverse populations of bees and wasps, and especially solitary bees, during apple flowering.

Despite their economic importance, there is a lack of information about the native pollinators of many orchard crops (including apple), pollinator abundance, and diversity (Kevan 1999), especially in Central Asia. Without the benefit of previous studies of pollinator diversity and abundance in the region, studies from other regions using similar methods were considered to gauge the abundance and richness of pollinator and parasitoids in Kyrgyz agro-ecosystems. Klein and co-authors (2003) classified agroecosystems that had $20+$ species as "species rich." In a similar temperate agro-ecosystem in Central Europe, though at lower elevations, Steffan-Dewenter and Leschke (2003) found 40 species of above-ground nesting bees and wasps at 45 different sites and they considered this is a "very high" number as compared to other similar studies. In other orchards, 32 species (Gardner and Ascher 2006) and 100 species of bees with capture 
rates from 2.5 - 5.8 bees per hour (Scott-Dupree and Winston 1987) were documented. Additionally, Scott-Dupree and Winston (1987) collected 29 species of bees from orchards that were near intact natural habitat, the most similar of the ecosystem types they sampled to those in this study. In a study in a similarly arid environment and in residential areas, 1871 individuals belonging to 54 different species of bees were collected from 36 sites, sampled twice during the year (McIntyre and Hostetler 2001). With an average capture rate of $19.7( \pm 1.46)$ bees and wasps per hour, the 40 species of bees and 10 wasps collected from 16 sites in this study in 2006 and, if 2005 data are considered, the 56 bees and 13 wasps collected support the designation of these agroecosystems as species rich. It is possible that diversity is actually higher in these systems, given that sampling efficiency, overall, was rather low at approximately $48 \%$. Using the ICE value for diversity, which takes into account species not encountered during sampling, for the two villages and both apple management systems in 2006, there are an estimated $80.4 \pm 3.84$ (std. dev.) species in these agro-ecosystems.

Using ANOSIM, I found that species richness and abundance of Hymenoptera, overall, were high with significant differences in the community composition of bees and wasps by locality but not by local land-use/ agro-ecosystem type (Fig. 7). Differences in Hymenopter by locality indicates that landscape-level factors are more important to bee community composition than local land-use management in this study. The community composition of social bees and wasps did not differ between locality or between home gardens and orchards. There were differences in the community composition of solitary bees between home gardens and orchards (Fig. 7). However, these differences could not 
be directly attributed to vegetation characteristics because, overall, there were no significant differences between home gardens and orchards as determined using ANOSIM. Though, examination of habitat characteristics separately showed there was significantly higher overstory richness and a higher number of overstory trees in home gardens, but no significant differences in basal area, overstory cover, percentage overstory in bloom, or ground cover in bloom (Table 1). Not finding significant differences in vegetation characteristics between home gardens and orchards was an unexpected finding given the radical differences in management between home gardens and orchards, but corresponds with Steffan-Dewenter and Leschke's (2003) findings of unexpectedly weak links between management and bee and wasp diversity.

Based on my observations, home gardens in this area have more complicated architecture, greater heterogeneity, and are much more intensively managed than the orchard plots, but many of these differences were either not detectable using the methods employed in this study, or these differences simply do not directly affect bees and wasps (Steffan-Dewenter and Leschke 2003). For example, the perimeter of home gardens (average size $0.21 \pm 0.04$ ha.) are composed of dense hedgerows and/or living fences of managed and unmanaged trees such as wild apricots (A.vulgaris), poplars (Populus), elms (Ulmus), and/or willows (Salix). Field margins and hedgerows are associated with increased insect abundance and diversity in agro-ecosystems, due to enhanced pollen and nectar sources and/or nesting sites, and may help explain why Hymenopteran diversity and abundance were high in this study (Kwaiser and Hendrix 2008; Woodcock et al. 2006; Pywell et al. 2006; Öckinger and Smith 2007; Carvell et al. 2007; Ekroos et al. 
2008). Orchards (18.60 \pm 3.22 ha.) also have the same type of perimeter but not the mosaic structure of home gardens, which is known to be important for insects (Perfecto and Vandermeer 2002; in Klein et al. 2003; Armbrecht et al. 2005), given the larger size of the orchards. However, hedgerows and margins were not sampled in this study.

Other factors that are known to promote bee diversity either do not vary as a result of management between home gardens and orchards, or simply do not apply during apple bloom. This study occurred, by design, during apple bloom in apple tree dominated agroecosystems, when trees were just beginning to leaf-out; it is possible the affects of management are simply not detectable that early in the growing season. Additionally, though home gardens are more intensively managed than orchards, these management practices do not include regular pruning in either orchards or home gardens (personal observation) meaning there are abundant nesting sites for both social and solitary wood and cavity nesters in dead wood (Michener 2000; Klein et al. 2003; Steffan-Dewenter and Leschke 2003; Osborne et al. 2008). Orchards tend to be walled, but the walls are weathered adobe, providing abundant nesting sites for solitary bees. The majority of solitary species collected during this research are primarily soil nesters but alternatively nest in banks or the similar weathered adobe (Michener 2000; McIntyre and Hostetler 2001; Gardner and Ascher 2006). Home gardens are also often walled-in with adobe, or, if not, homes and small barns are almost exclusively adobe, simulating exposed banks, and bees nesting in the walls are tolerated (personal observation). 
Though repeated over two years, I did not sample any time other than during bloom. Perhaps there are differences in the community composition of both vegetation and insects not associated with apple pollination that were not detected. While other studies have found that social bees are attracted to floral clusters and solitary bees more attracted to blossom cover of herbaceous plants (Klein 2003; Potts et al. 2003; Steffan-Dewenter and Leschke 2003; Winfree et al. 2008) this type of analysis is simply not possible, because of the lack of alternative nectar sources. Apples bloom in clusters and, other than apples, there were very few alternative nectar and pollinator sources available during apple bloom in either home gardens or orchards, other than trace occurrences of Taraxacum spp., dandelions, just beginning to flower. The availability of floral resources throughout the growing season, a factor important to bee community structure (SteffanDewenter and Leschke 2003), was not studied.

A habitat factor that was measured in this study, and found to be important for Hymenoptera abundance and diversity in another insect study, was the height of vegetation (Kruess and Tscharntke 2002). The overall number of individuals, number of bee individuals, number of solitary bee individuals and number of solitary bee species significantly decreased as the height of the ground cover vegetation increased while the abundance of social bees and wasps were not related to ground cover height (Table 2; Figs. 2, 3). While Kruess and Tscharntke (2002) also found that mean vegetation height best predicted the abundance and number of species of non-parasitic, solitary bees and wasps, the direction of the relationship was opposite from this study (increasing with height of vegetation). Perhaps the immaturity of annual vegetation associated with the 
early sampling dates in this study may be a factor, or the need to measure not just the height of ground cover vegetation, but all variation in foliage height diversity (MacArthur and MacArthur 1961). The abundance of wasps was related to a different variable; wasp abundance and species diversity significantly decreased as the percentage ground cover increased (Fig. 5).

I found that locality was important to the overall community composition of Hymenoptera (Fig. 7). Perhaps Hymenoptera in this area are dependent on landscapelevel environmental variables (Steffan-Dewenter 2003; Schmidt et al. 2005; Klein et al. 2007; Rundölf et al. 2008; Winfree et al., 2008) or are responding to differences in habitat connectivity and/or habitat area (Steffan-Dewenter 2003). The high quality habitat of the agro-ecosystems may help explain why there were no strong differences in Hymenoptera community composition between home gardens and orchards (local management) (Rundölf et al. 2008; in Steffan-Dewenter and Westphal 2008). Both home gardens and orchards in this study have a number of characteristics that are known to encourage diverse pollinator communities. Home gardens, more so than orchards, are architecturally complex; both have diverse margins and hedgerows; and both provide abundant nesting sites for pollinators. Both home gardens and orchards are organic, as pesticides have not been widely available in this area since the collapse of the Soviet Union. Changes that have been difficult for households (Seeth et al. 1998) have, indirectly, been a good thing for the pollinator fauna in Kyrgyzstan. 


\section{Acknowledgments}

I would like to thank A. Orozumbekov and N. Eshimov for collecting and mounting specimens; D. Milko, Department of Entomology, Institute for Biology and Pedology, National Academy of Sciences, Kyrgyz Republic for insect identification; the Agricultural University of Kyrgyzstan for hosting me; residents of Tosor and Tamga for providing access to their home gardens and orchards; Daria Toguzbaeva; Anna Ostashko for statistical consulting; and S. Koptur and D. Lee for comments on early drafts. The research described in this paper has been funded in part by the United States Environmental Protection Agency (EPA) under the Science to Achieve Results (STAR) Graduate Fellowship Program, Florida International University’s Presidential Enhancement Award, the Institute for International Education's Fulbright Graduate Research Fellowship, and the National Geographic Society Conservation Trust (C61-05). This publication is not officially endorsed by EPA and may not reflect the views of the agency. 


\section{LIST OF REFERENCES}

Altieri MA (2004) Linking ecologists and traditional farmers in the search for sustainable agriculture. Front Ecol Environ 2:35-42

Armbrecht I, Rivera L, Perfecto I (2005) Reduced diversity and complexity in the leaflitter ant assemblage of Colombian coffee plantations. Conserv Biol 19:897-907

Banaszak J (1992) Strategy for conservation of wild bees in an agricultural landscape. Agric Ecosyst Environ 40:179-192

Billeter R, Liira J, Bailey D, Bugter R, Arens P, Augenstein I, Aviron S, Baudry J, Bukacek R, Burel F, Cerny M, De Blust G, De Cock R, Diekötter T, Dietz H, Dirksen J, Dormann C, Durka W, Frenzel M, Hamersky R, Hendrickx F, Herzog F, Klotz S, Koolstra B, Lausch A, Le Coeur D, Maelfait JP, Opdam P, Roubalova M, Schermann A, Schermann N, Schmidt T, Schweiger O, Smulders MJM, Speelmans M, Simova P, Verboom J, van Wingerden WKRE, Zobel M, Edwards PJ (2008) Indicators for biodiversity in agricultural landscapes: a pan-European study. J Appl Ecol 45:141-150

Buchmann SL, Nabhan GP (1996) The Forgotten Pollinators. Island Press, Washington, D.C.

Carpenter C, Fe, G., Fet V (2001) Tian Shan foothill arid steppe (PA0818). In: Terrestrial Ecoregions of the World. http://www.worldwildlife.org/wildworld/profiles/terrestrial/pa/pa0818_full.html. Cited 22 May 2008

Carvell C, Meek WR, Pywell F, Goulson D,Nowakowski M (2007) Comparing the efficacy of agri-environment schemes to enhance bumble bee abundance and diversity on arable field margins. J Appl Ecol 44:29-40

Chazdon RL, Colwell RK, Denslow JS, Guariguata MR (1998) Statistical methods for estimating species richness of woody regeneration in primary and secondary rain forests of NE Costa Rica. In: Dallmeier F, Comiskey JA (eds) Forest biodiversity research, monitoring and modeling: Conceptual background and Old World case studies.

Parthenon Publishing, Paris, pp285-309

Chelpakova JM, Milko, DM (2004) Biologicheskoye rsnoobrazie nasekomych y nekotorye aspecty biosfery Issyk-kulskoy territorii. Practika Pyatogo Issyk-Kulskogo Simposiuma. (The insect biodiversity and some aspects of its conservation in the YsykKol territoty of Biosphere. Proceedings of the 5th Issyk-Kul Symposium.) Bishkek, Kyrgyzstan. 
Colwell RK (2006) EstimateS: Statistical estimation of species richness and shared species from samples. Version 8.0. User's Guide and application published at: http://purl.oclc.org/estimates.

Colwell RK, Coddington JA (1994) Estimating terrestrial biodiversity through extrapolation. Philos T Roy Soc B 345:101-118

Colwell RK, Mao CX, Chang J (2004) Interpolating, extrapolating, and comparing incidence-based species accumulation curves. Ecology 8:2717-2727

Dietsch TV, Perfecto I, Greenberg R (2007) Avian foraging behavior in two different types of coffee agroecosystem in Chiapas, Mexico. Biotropica 39:232-240

Dzhangaliev AD, Salova TN, Turekhanova PM (2003) The wild fruit and nut plants of Kazakhstan. In: Janick J (ed.) Wild Apple and Fruit Trees of Central Asia, Horticultural Reviews Vol 29. John Wiley \& Sons, Inc. New Jersey.

ECONET (2008) Factsheet - Kyrgyzstan. In: Econet of Kyrgyzstan. http://www.wwf.ru/data/asia/econet_maps/kyrgyzstaneng.doc. Cited 21 May 2008

Ekroos J, Piha M, Tiainen J (2008) Role of organic and conventional field boundaries on boreal bumblebees and butterflies. Agric Ecosyst Environ 124:155-159

Eastwood A, Lazkov G, Newton A (2009) The Red List of Trees of Central Asia. Fauna and Flora International, Cambridge, UK.

Fernandes ECM, Nair PKR (1986) An evaluation of the structure and function of tropical homegardens. Agr Syst 2:279-310

Forsline PL, Aldwinckle HS, Dickson EE, Luby JJ, Hokanson SC (2003) Collection, maintenance, characterization, and ultilization of wild apples of Central Asia. In: Janick J (ed.) Wild Apple and Fruit Trees of Central Asia, Horticultural Reviews Vol 29. John Wiley \& Sons, Inc. New Jersey.

Gardner KE, Ascher JS (2006) Notes on the native bee pollinators in New York apple orchards. J New York Entomol Soc 114:86-91

Hammer Ø, Harper D, Ryan P (2001) Past: paleontological statistics software package for education and data analysis. Palaeontol Electron 4:1-9. Available via http://folk.uio.no/ohammer/past/. Cited 9 June 2008

IUCN (2007) 2007 IUCN Red List of Threatened Species. Version 2009.1. www.iucnredlist.org. Cited 07 June 2009 
Jailov J (2006) Informatsiya iz Ayil Okmotu ot 25.07.2006 goda (Information from Local Village Government for 25.07.2006). Tamga Local Village Administration, Tamga, Kyrgyz Republic.

Kearns CA, Inouye DW (1997) Pollinators, flowering plants, and conservation biology. BioScience 47:297-307

Kearns CA (2001) North American dipteran pollinators: assessing their value and conservation status. Conserv Ecol 5:5. Available via http://www.consecol.org/vol5/iss1/art52001.

Kevan PG (1999) Pollinators as bioindicators of the state of the environment: species, activity and diversity. Agric Ecosyst Environ 74:373-393

Klein AM, Vaissière BE, Cane J, Steffan-Dewenter I, Cunningham SA, Kremen C, Tscharntke T (2007) Importance of pollinators in changing landscapes for world crops. $P$ Roy Soc Lond B Bio 274:303-313

Klein A, Steffan-Dewenter I,Tscharntke T (2003) Bee pollination and fruit set of Coffea canephora in relation to local and regional agroforestry management. J Appl Ecol 40:837-845

Kruess A, Tscharntke T (2002) Grazing intensity and the diversity of grasshoppers, butterflies, and trap-nesting bees and wasps. Conserv Biol 16:1570-1780

Krever V, Pereladova O, Williams M, Jungius H (1998) Biodiversity conservation in Central Asia: An analaysis of biodiversity and current threats and initial investment portfolio. Wild Fund for Nature (WWF), Moscow. Available via http://www.wwf.ru/resources/publ/book/eng/36. Cited 22 May 2008

Kwaiser KH, Hendrix SD (2008) Diversity and abundance of bees (Hymenoptera: Apiformes) in native and ruderal grasslands of agriculturally dominated landscapes. Agric Ecosyst Environ 124:200-204

Lerman Z, Stanchin I (2004) Institutional changes in Turkmenistan's agriculture: impacts on productivity and rural incomes. Eurasian Geogr Econ 45:60-72

Logino JT, Coddington J, Colwell RK (2002) The ant fauna of a tropical rain forest: estimating species richness three different ways. Ecology 83:689-702

MacArthur, RH, MacArthur, JW (1961) On bird species diversity. Ecology 42:594-598.

Mas AH, Dietsch TV (2004) Linking shade coffee certification to biodiversity conservation: butterflies and birds in Chiapas, Mexico. Ecol Appl 14:642-654 
McGregor SE (1976) Insect Pollination of Cultivated Crops. Washington, DC: USDA Agriculture Handbook No. 496, US Government Printing Office. Available via http://gears.tucson.ars.ag.gov/book/. Cited 2 October 2008.

McIntyre NE, Hostetler ME (2001) Effects of urban land use on pollinator (Hymenoptera: Apoidea) communities in a desert metropolis. Basic Appl Ecol 2:209-218

Michener CD (2000) The Bees of the World. The Johns Hopkins University Press, Baltimore, MD.

Ministry of Environmental Protection (1998) Kyrgyz Republic biodiversity strategy and action plan. Ministry of Environmental Protection, Bishkek, Kyrgyz Republic.

National Statistics Committee of the Kyrgyz Republic (2008) Sel'skoe khozyaistvo Kyrgyzskoy Respubliki 2005-2007 (Agriculture in the Kyrgyz Republic 2005-2007). National Statistical Committee of the Kyrgyz Republic, Bishkek.

Öckinger E, Smith HG (2007) Semi-natural grasslands as population sources for pollination insects in agricultural landscapes. J Appl Ecol 44:50-59

Osborne JL, Martin AP, Shortall CR, Todd AD, Goulson D, Knight ME, Hale RJ, Sanderson, RA (2008) Quantifying and comparing bumblebee nest densities in gardens and countryside habitats. J Appl Ecol 44:50-59

Ostashko A, Currey R (2007) Household Surveys in the Kyrgyz Republic, 2006: An Economic Profile of Home Gardeners. Mercy Corps Kyrgyzstan and Kompanion Financial Group, Bishkek, Kyrgyz Republic.

Partap U, Partap T (2002) Warning signals from the apple valleys of the Hindu KushHimalayas: productivity concerns and pollination problems. International Centre for Integrated Mountain Development, Kathmandu, Nepal.

Perfecto I, Mas A, Dietsch TV, Vandermeer J (2003) Species richness along an agricultural intensification gradient: a tri-taxa comparison in shade coffee in southern Mexico. Biodivers Conserv 12:1239-1252

Perfecto I, Vandermeer J (2002) The quality of the agroecological matrix in a tropical montane landscape: ants in coffee plantations in southern Mexico. Conserv Biol 16:174182

Perfecto I, Vandermeer J, Mas A, Pinto LS (2005). Biodiversity, yield and shade coffee certification. Ecol Econ 54:435-446

Pratt C (1988) Apple flower and fruit: morphology and anatomy. Hortic Rev 10:273-308 
Pywell RF, Warman EA, Sparks TH, Humes L, Nuttall P, Hulmes S, Wright A, Saunders P, Boyd J, Taylor A, Chapman R, Peat J, Critchley CNR, Sherwood A (2006)

Effectiveness of new agri-environmental schemes in providing foraging resources for bumblebees in intensively farmed landscapes. Biol Conserv 129:192-206

Rundölf M, Bengtsson J, Smith HG (2008) Local and landscape effects of organic farming on butterfly species richness and abundance. J Appl Ecol 45:814-821

Schmidt MH, Roschewitz I, Thies C, Tscharntke T (2005) Differential effects of landscape and management on diversity and density of ground-dwelling farmland spiders. J Appl Ecol 42:281-287

Scott-Dupree CD, Winston ML (1987) Wild bee pollinator diversity and abundance in orchard and uncultivated habitats in the Okanagan Valley, British Columbia. Can Entomol 119:735-745

Seeth HT, Chachnow S, Surinov A, von Braun J (1998) Russian Poverty: Muddling through economic transition with garden plots. World Dev 26:1611-1623

Sokal RR, Rohlf FJ (1995) Biometry: The Principles and Practice of Statistics in Biological Research, $3^{\text {rd }}$ edn. WH Freeman, New York.

Steffan-Dewenter I (2003) The importance of habitat area and landscape context for species richness of bees and wasps in fragmented orchard meadows. Conserv Biol $17: 1036-1044$

Steffan-Dewenter I, Leschke K (2003) Effects of habitat management on vegetation and above-ground nesting bees and wasps of orchard meadows in Central Europe. Biodiv Conserv 12:1953-1968

Steffan-Dewenter I, Westphal C (2008) The interplay of pollinator diversity, pollination services and landscape change. J Appl Ecol 45:737-741

SYSTAT (2007) SYSTAT for Windows. Version No. 12.02.00. SYSTAT Software, Inc.

Ter-Ghazaryan D, Heinen JT (2006) Reserve management during Transition: The case of Issyk-kul Biosphere and Nature Reserves, Kyrgyzstan. Environ Pract 8:11-23

Watling JI, Donnelly MA (2008) Species richness and composition of amphibians and reptiles in a fragmented forest landscape in northeastern Bolivia. Basic Appl Ecol 9:523532

Winfree R, Williams NM, Gaines H, Ascher JS, Kremen C (2008) Wild bee pollinators provide the majority of crop visitation across land-use gradients in New Jersey and Pennsylvania, USA. J Appl Ecol 45:794-803 
Woodcock BA, Potts SG, Pilgrim E, Ramsay AJ, Tscheulin T, Parkinson A, Smith REN, Gundrey AL, Brown VK, Tallowin JR (2006) The potential of grass field margin management for enhancing beetle diversity in intensive livestock farms. J Appl Ecol 44:60-69

World Bank Kyrgyz Republic (2005) Farm structure and agricultural productivity. Kyrgyzstan Agriculture Sector: Policy Note 2. World Bank Country Office in the Kyrgyz Republic, Bishkek. 
Figure. 1. Sample-based (Mao Tau) rarefaction curves with $95 \%$ confidence intervals for Hymenoptera between (a) home gardens (squares) and orchards (triangles) in 2006; (b) locality, or village, (Tamga, squares; Tosor, triangles); and (c) years (2005, triangles; 2006, squares).
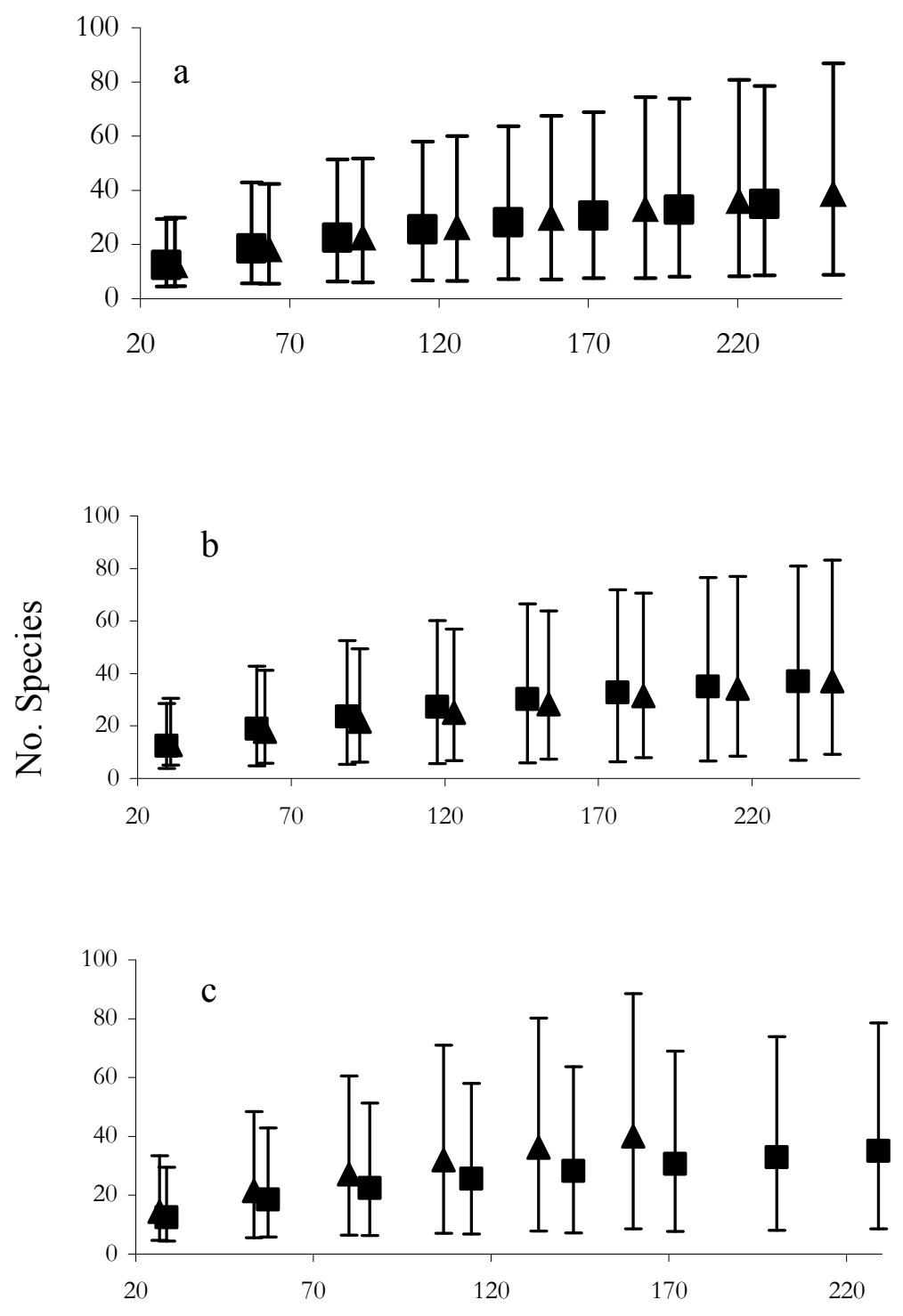

No. of Individuals 
Figure. 2. Results of simple linear regressions showing the relationship between (a) the number of Hymenopteran individuals $(\mathrm{F}=17.84, \mathrm{~N}=16, \mathrm{P}=0.001)$ and $(\mathrm{b})$ the number of bee individuals $(\mathrm{F}=13.00, \mathrm{~N}=16, \mathrm{P}=0.003)$ and the height of ground cover vegetation.

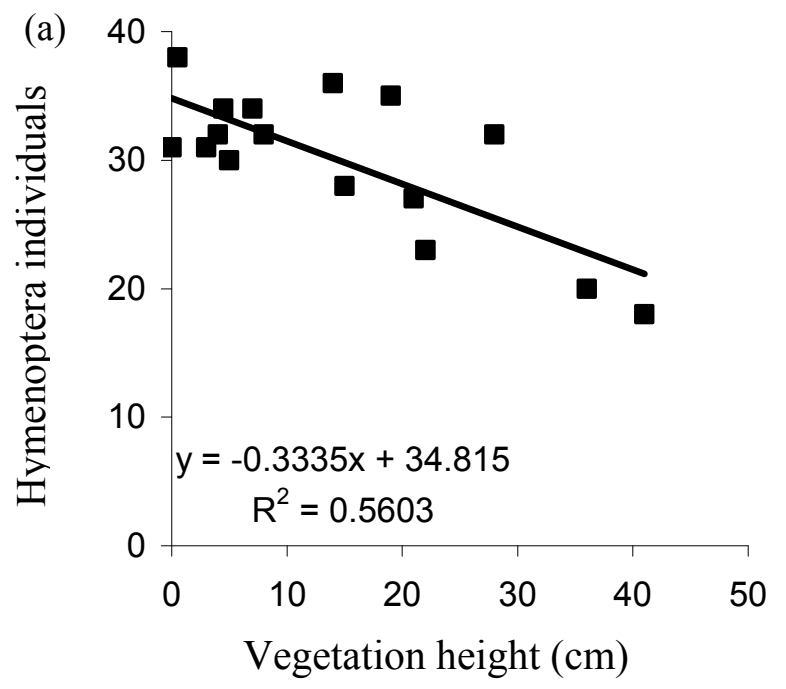

(b)

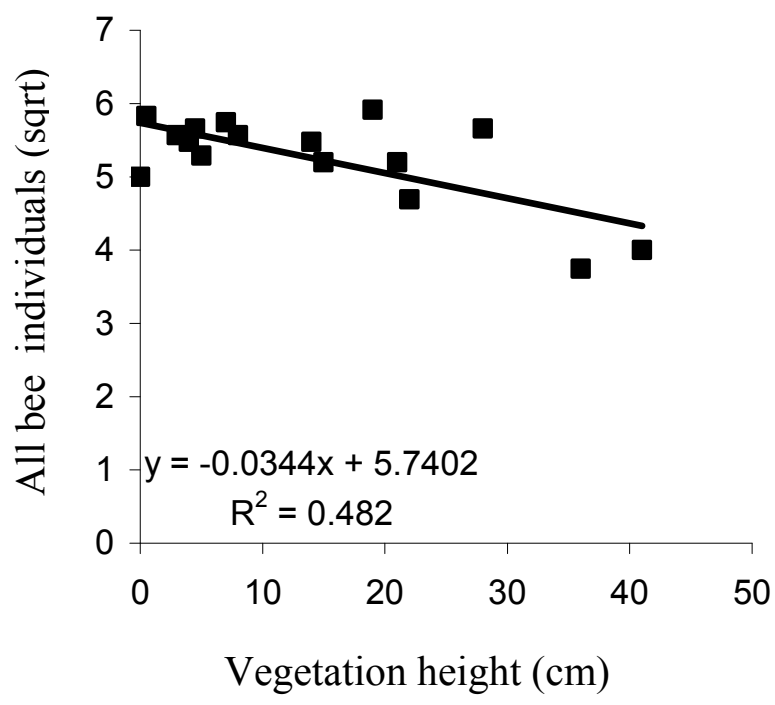


Figure. 3. Results of simple linear regressions showing the relationship between (a) the number of solitary bee individuals $(\mathrm{F}=15.181, \mathrm{~N}=16, \mathrm{P}=0.002)$ and $(\mathrm{b})$ the number of solitary bee species $(\mathrm{F}=5.256, \mathrm{~N}=16, \mathrm{P}=0.038)$ and the height of ground cover vegetation.
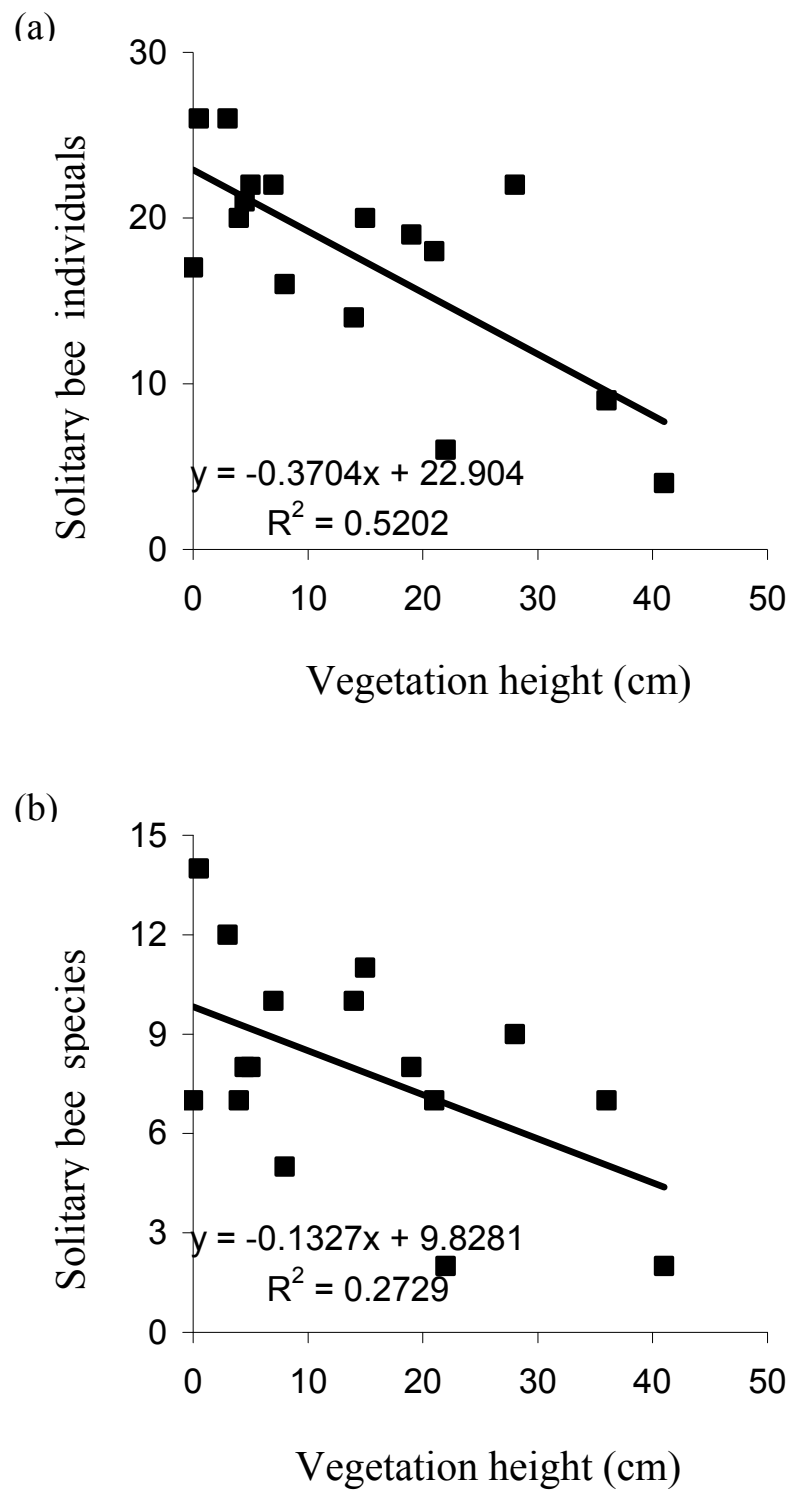
Figure. 4. Results of simple linear regressions showing the relationship between (a) the number of social bee species $(\mathrm{F}=6.91, \mathrm{~N}=16, \mathrm{P}=0.020)$ and $(\mathrm{b})$ the number of bumble bee species $(\mathrm{F}=6.91, \mathrm{~N}=16, \mathrm{P}=0.020)$ and the percent vegetative ground cover (logit transformed).

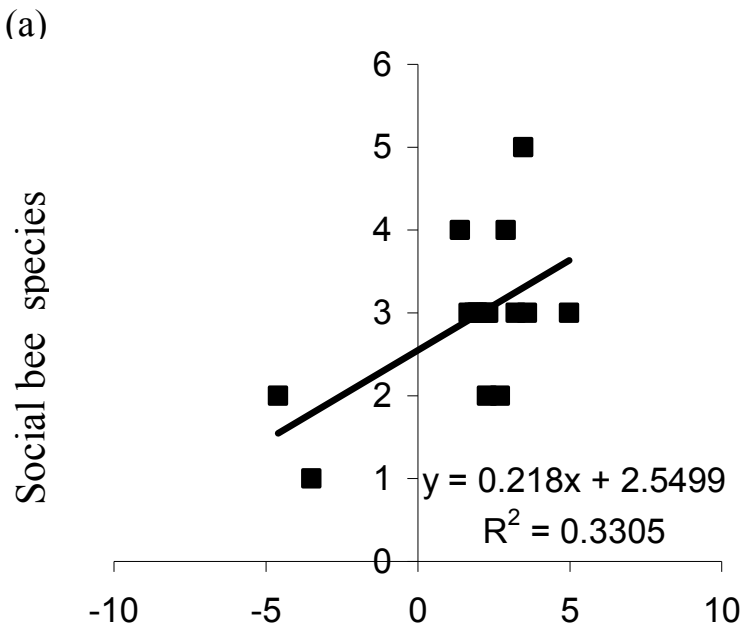

Vegetative ground cover (logit)

(b)

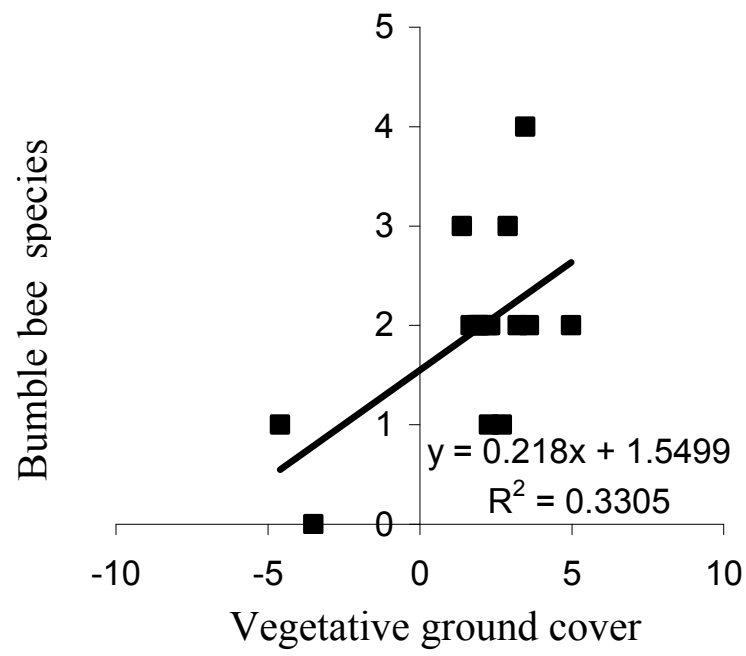

(logit) 
Figure. 5. Results of simple linear regressions showing the relationship between (a) the number of wasp individuals $(\mathrm{F}=8.88, \mathrm{~N}=16, \mathrm{P}=0.020)$ and $(\mathrm{b})$ the number of wasp species $(\mathrm{F}=6.81, \mathrm{~N}=16, \mathrm{P}=0.021)$ and the percent vegetative ground cover (logit transformed).
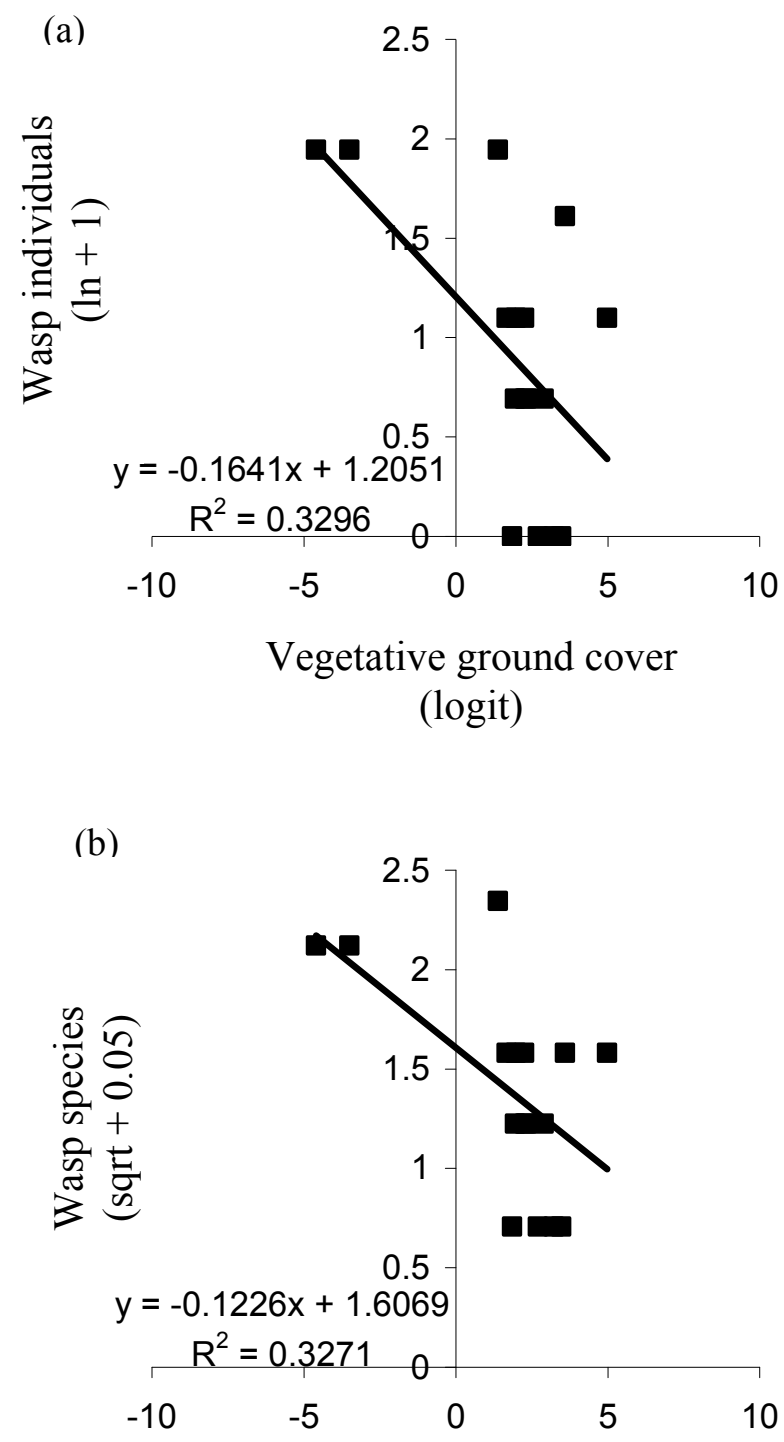

Vegetative ground cover (logit) 
Figure. 6. Results of simple linear regression showing the relationship between the number of bumble bee individuals and the percent of overstory cover $(\mathrm{F}=6.12, \mathrm{~N}=16, \mathrm{P}$ $=0.027$ ).

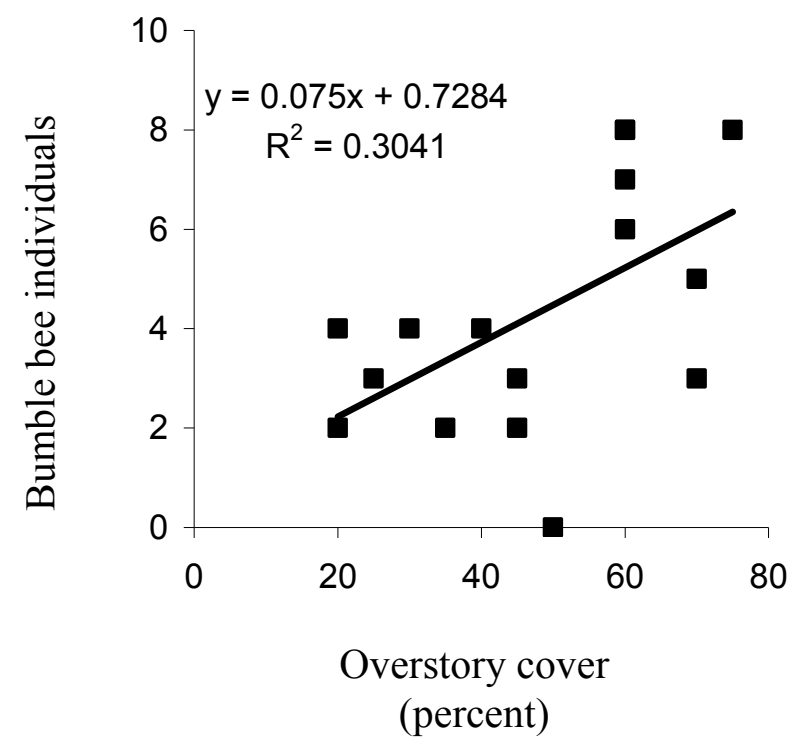


Figure. 7. NMDS plots of species community composition between: (a) Hymenoptera species and locality (village); (b) solitary bees and agro-ecosystem type: home gardens and orchards; and (c) solitary bees and locality (villages Tosor and Tamga, $12 \mathrm{~km}$ apart).

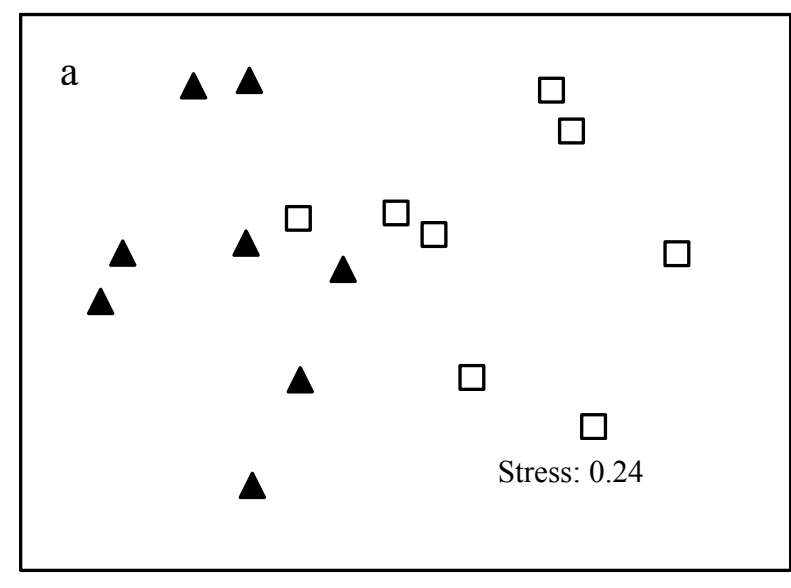

$\Delta$ Tosor $\quad \square$ Tamga

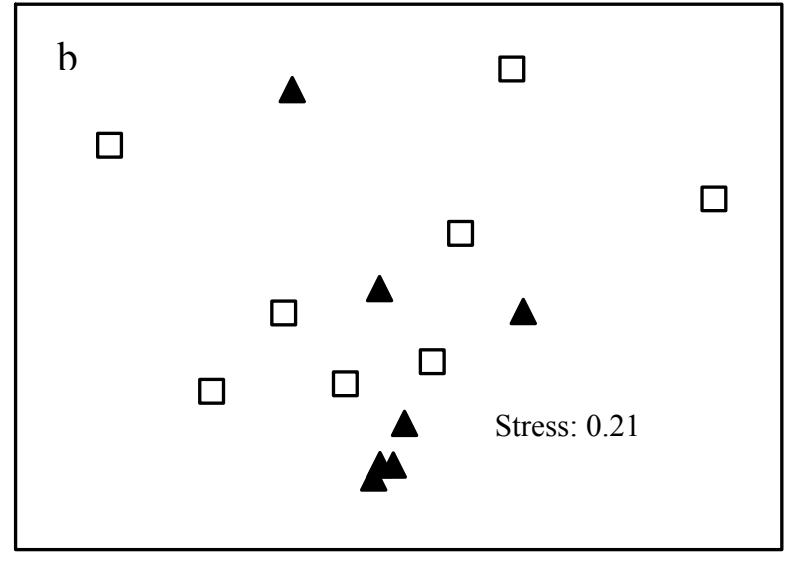

$\Delta$ Orchard $\square$ Home garden

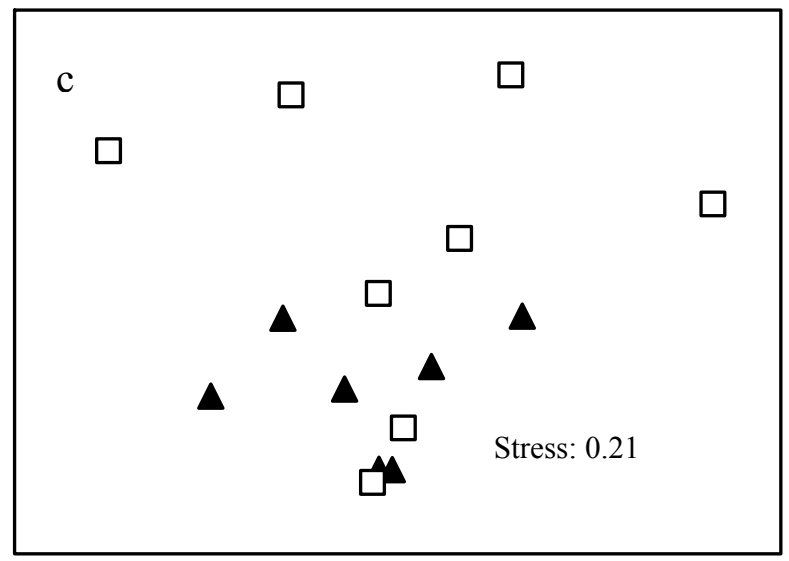

$\Delta$ Tosor $\quad \square$ Tamga 
Table 1. Characteristics of home gardens $(\mathrm{N}=8)$ and orchards $(\mathrm{N}=8)$ in two villages, Issyk-kul Region, Kyrgyzstan

\begin{tabular}{|c|c|c|c|}
\hline & Total & Home Gardens & Orchards \\
\hline $\begin{array}{l}\text { Size (ha.) } \\
\text { (Std. Error) }\end{array}$ & - & $\begin{array}{c}0.21 \\
0.037\end{array}$ & $\begin{array}{l}18.60 \\
3.220\end{array}$ \\
\hline Trees (total number) & $\begin{array}{r}5.31 \\
0.395\end{array}$ & $\begin{array}{c}6.25 \\
0.590\end{array}$ & $\begin{array}{r}4.38 \\
0.263\end{array}$ \\
\hline Proportion Apple & $\begin{array}{r}0.86 \\
0.515\end{array}$ & $\begin{array}{c}0.75 \\
0.832\end{array}$ & $\begin{array}{r}0.97 \\
0.313\end{array}$ \\
\hline Overstory Cover (\%) & $\begin{array}{r}47.81 \\
4.54\end{array}$ & $\begin{array}{l}51.88 \\
6.404\end{array}$ & $\begin{array}{l}43.75 \\
6.529\end{array}$ \\
\hline Overstory in Flower (\%) & $\begin{array}{l}21.88 \\
3.840\end{array}$ & $\begin{array}{l}25.63 \\
7.035\end{array}$ & $\begin{array}{l}18.13 \\
3.125\end{array}$ \\
\hline Basal Area of Trees $\left(\mathrm{m}^{2}\right)$ & $\begin{array}{r}0.15 \\
0.021\end{array}$ & $\begin{array}{c}0.18 \\
0.035\end{array}$ & $\begin{array}{r}0.12 \\
0.020\end{array}$ \\
\hline Vegetative Ground Cover (\%) & $\begin{array}{l}80.03 \\
7.728\end{array}$ & $\begin{array}{c}69.22 \\
14.776\end{array}$ & $\begin{array}{l}90.84 \\
2.051\end{array}$ \\
\hline Height of Ground Cover $(\mathrm{cm})$ & $\begin{array}{l}14.25 \\
3.164\end{array}$ & $\begin{array}{l}13.69 \\
5.683\end{array}$ & $\begin{array}{l}14.81 \\
3.243\end{array}$ \\
\hline
\end{tabular}


Table 2. Results of stepwise multiple regression analyses for dependent variables and the independent variables of overstory cover, percent overstory in bloom, height of vegetation, and percent vegetative ground cover.

\begin{tabular}{|c|c|c|c|c|c|}
\hline Dependent variables & Habitat Factor & $t$ & $p$ & $\begin{array}{l}\text { Whole } \\
\text { model } \\
r^{2}\end{array}$ & $\begin{array}{l}\text { Whole } \\
\text { model P }\end{array}$ \\
\hline All individuals & Vegetation height $(\mathrm{cm})$ & -4.22 & 0.001 & 0.560 & 0.001 \\
\hline All species & Vegetation height $(\mathrm{cm})$ & -1.99 & 0.067 & 0.220 & ns \\
\hline All bee individuals & $\begin{array}{l}\text { Vegetation height }(\mathrm{cm}) \\
\text { Vegetative ground cover }(\%)\end{array}$ & $\begin{array}{r}-4.54 \\
2.60\end{array}$ & $\begin{array}{l}0.001 \\
0.022\end{array}$ & 0.659 & 0.001 \\
\hline Bee species & Vegetation height $(\mathrm{cm})$ & -2.05 & 0.060 & 0.231 & ns \\
\hline Social bee individuals & - & - & - & - & \\
\hline \multirow{3}{*}{$\begin{array}{l}\text { A. mellifera } \\
\text { individuals } \\
\text { Bombus spp. } \\
\text { individuals }\end{array}$} & - & - & - & - & \\
\hline & Overstory cover (\%) & 2.68 & 0.019 & & \\
\hline & Vegetative ground cover $(\%)$ & 1.99 & 0.068 & 0.467 & 0.017 \\
\hline Social bee species & Vegetative ground cover $(\%)$ & 2.63 & 0.020 & 0.331 & 0.020 \\
\hline Bombus spp. species & Vegetative ground cover $(\%)$ & 2.63 & 0.020 & 0.331 & 0.020 \\
\hline Solitary bee individuals & Vegetation height $(\mathrm{cm})$ & -3.90 & 0.002 & 0.520 & 0.002 \\
\hline Solitary bee species & Vegetation height $(\mathrm{cm})$ & -2.29 & 0.038 & 0.273 & 0.038 \\
\hline Wasp individuals & Vegetative ground cover $(\%)$ & -2.62 & 0.020 & 0.330 & 0.020 \\
\hline Wasp species & Vegetative ground cover $(\%)$ & -2.61 & 0.021 & 0.327 & 0.021 \\
\hline
\end{tabular}




\section{CHAPTER V}

\section{NEW HYMENOPTERA RECORDS FROM APPLE AGROECOSYSTEMS, ISSYK-KUL BASIN, KYRGYZ REPUBLIC}

Key Words: Central Asia, Hymenoptera, Kyrgyz Republic, Orchard

Twelve new occurrences of Hymenopterans from seven families (eight genera) are documented from Issyk-kul Province (IK), north-eastern Kyrgyz Republic (KR) by listing each species in turn, noting the gender and number of specimens collected, locations and dates of collection, and details of the species' distribution. Six species are new records for Kyrgyzstan and six are new records for IK. Specimens were collected in homegardens and orchards in Tosor and Tamga villages, on the south shore of Lake Issyk-Kul, Djeti-Oguz, IK, KR in May, 2005 and 2006 (Krever et al. 1998, Carpenter et al. 2001, Surappaeva \& Milko 2006, ECONET 2008) using 30 minute sweep netting intervals within randomized $25 \mathrm{~m}^{2}$ plots during apple (Malus X domestica Borkh.) bloom (Currey, unpublished). Panfilov (1962), Shukurov and Tarbinsky (1996), Chelpakova and Milko (2004), Milko (2006), and Surappaeva and Milko (2006) provide the history and descriptions of the entomology of Kyrgyzstan and IK. Original specimens are deposited in the collection at the Department of Entomology, Institute for Biology and Pedology, National Academy of Sciences, Bishkek, KR (IBB) with additional specimens in Currey's collection (FIU). 
Order Hymenoptera

Family Ichneumonidae

Buathra evidens (Kokujev, 1909)

1§ึ, Issyk-Kul Province, Djeti-Oguz, Tosor, LAT 42 10.174-N; LON 77 26.738-E, 1623

m, 25.v.2005, AO (FIU).

Middle Asian endemic species described from the Alai Mountains and the Alai-Pamir region in southernmost Kyrgyzstan, along the Tajikistan border (Shukurov \& Tarbinsky 1996), but recorded for the first time in northern Kyrgyzstan.

Family Vespidae

Subfamily Eumeninae

Antepipona orbitalis (Herrich-Schäffer, 1839) ssp. ballioni (F. Morawitz, 1867)

1§ึ, Issyk-Kul Province, Djeti-Oguz, Tamga, LAT 42 09.350-N; LON 77 32.697-E, 1675

m, 12.v.2006, AO (IBB).

Widely distributed in the Palaearctic Region with the subspecies ballioni reported from eastern Turkey, Crimea, Caucasus, Volga Region, Kazakhstan, northern Kyrgyzstan, western Siberia and Irkutsk Province, Russia (Shukurov \& Tarbinsky 1996). It is registered in IK for the first time.

Eumenes mongolicus F. Morawitz, 1889

10, Issyk-Kul Province, Djeti-Oguz, Tosor, LAT 42 08.014-N; LON 77 32.064-E, 1698 m, 05.v.2006, AO (IBB). 
Current distribution includes south-eastern Siberia, Mongolia and northern China (Kurzenko 1995). This is the first record in Kyrgyzstan, extending the known distribution of this rare species to the west.

Family Sphecidae Crossocerus (Blepharipus) megacephalus (Rossi, 1790) (=leucostomus auct. non L., =zaidamensis Radoszkowski, 1887, =leucostomoides Richards, 1935)

1우, Issyk-Kul Province, Djeti-Oguz, Tosor, LAT 42 08.014-N; LON 77 32.064-E, 1698 m, 18.v.2005, AO (IBB).

Known from Tunisia, Europe, Turkey, Tadjikistan, Kazakhstan, the Altai, Irkutsk and Amur provinces (Russia) and Mongolia (Kazenas 2001), but this is the first record for Kyrgyzstan.

Family Andrenidae Andrena (Melandrena) nitida (Müller, 1776) (=pubescens Olivier, 1789) 1§ึ, Issyk-Kul Province, Djeti-Oguz, Tosor, LAT 42 08.014-N; LON 77 32.064-E, 1698 m, 16.v.2005, AO (FIU).

A widely distributed species known in the Palaearctic Region from Northern Africa and Iraq to Finland and Siberia, but is new for the Kyrgyz Cadastre (Shukurov \& Tarbinsky 1996). 
Andrena (Micrandrena) subopaca Nylander, 1848

19, Issyk-Kul Province, Djeti-Oguz, Tosor, LAT 42 08.014-N; LON 77 32.064-E, 1698

m, 13.v.2005, AO (FIU); 1 ㅇ Issyk-Kul Province, Djeti-Oguz, Tosor, Tokoon Alyshova’s Garden, 1650 m, 11.v.2005, AO (FIU).

There is no record of this trans-Palaearctic polytrophic bee species in Kyrgyzstan until these two specimens.

Andrena (Plastandrena) bimaculata (Kirby, 1802)

19, Issyk-Kul Province, Djeti-Oguz, Tamga, LAT 42 09.350-N; LON 77 32.697-E, 1675

m, 12.v.2006, AO (FIU).

This species is widely distributed in the Western Palaearctic from England and Finland to Northern Africa, Iraq and the Urals, but is the first record for Kyrgyzstan.

Andrena (Tarsandrena) ehnbergi F. Morawitz, 1888

1우, Issyk-Kul Province, Terskei Alatoo Mountain Range., 5 km S Barskaun village, 1850 m, 5.vii.1999 (IBB); 6 우, Issyk-Kul Province, Djeti-Oguz, Tosor, LAT 42 10.174N; LON 77 26.738-E, 1623 m, 12-17.v.2005, AO (FIU); 5 क, Issyk-Kul Province, DjetiOguz, Tosor, LAT 42 10.322-N; LON 77 26.349-E, 1623 m, 13.v.2006, AO (FIU). This sporadically distributed species was recorded in Bashkortostan, Kazakhstan, Tadjikistan, southern Siberia, Mongolia and the Russian Far East. There is a single indication for Kyrgyzstan, but without information as to where it was collected (Osytshnjuk 1995). Given this lack of information for the single previous record and that these are the first specimens of this species in the collection at the Kyrgyz National 
Academy of Sciences, we note these specimens as the first records for northern Kyrgyzstan.

Andrena (Zonandrena) chrysopyga Schenck, 1853

19, Issyk-Kul Province, Djeti-Oguz, Tosor, LAT 42 09.680-N; LON 77 27.687-E, 1617

m, 10.v.2006, AO (FIU).

A west-Palaearctic species widely spread in temperate regions, including the Western Tien Shan, registered in Kyrgyzstan for the first time extending the known range of this species to the east (Beskokotov 1996).

Family Halictidae

Sphecodes pellucidus F.Smith, 1845

1우, Issyk-Kul Province, Djeti-Oguz, Tosor, Asankul Namazbekov’s Garden, 1622 m, 25.v.2005, AO (FIU).

Widely distributed parasitic species in Europe, the territory of the former Soviet Union and the northern Caucasus, but registered in Kyrgyzstan for the first time (Michener 2000).

Family Megachilidae

Hoplitis (Megalosmia) fulva (Eversmann, 1852) (=grandis Morawitz, 1873)

1§, Issyk-Kul Province, Djeti-Oguz, Tosor, LAT 42 10.174-N; LON 77 26.738-E, 1623

m, 17.v.2005, AO (IBB); 
A sporadically spread species, the large colonial $H$. fulva is known in arid lowlands from south-eastern Europe to Turkey, Armenia and Kazakhstan to Chinese Dzhungar and south-eastern Sichuan (Popov 1962). It is listed as rare and endangered in two regional Red Lists (see Meldebekov 2006), but was omitted from the Kyrgyz Cadastre (Shukurov \& Tarbinsky 1996), even though it was reported for north-eastern Kyrgyzstan (Popov 1962). This is a new record for IK.

Family Anthophoridae

Anthophora fulvitarsis Brulle, 1832

1옹 Issyk-Kul Province, Djeti-Oguz, Tosor, LAT 42 10.322-N; LON 77 26.349-E, 1623

m, 11.v.2006, AO (FIU); 1, Issyk-Kul Province, Djeti-Oguz, Tamga, LAT 42 09.350-

N; LON 77 32.697-E, 1675 m, 12.v.2006, AO (IBB).

Ancient Mediterranean thermophilic species distributed from the Iberian Peninsula to Northern Xinjiang and Eastern Kazakhstan. This species is registered in IK for the first time and was registered only once before in the Alexander Mountain Range, northwestern Kyrgyzstan (Milko \& Makogonova 1999).

Summary

We report 12 species of Hymenoptera that are new records for Kyrgyzstan (6 species) or within Kyrgyzstan (6 species). 


\section{Acknowledgments}

The authors would like to thank A. Orozumbekov and N. Eshimov for collecting and mounting specimens; D.V. Logunov (Manchester University) for help with literature; and S. Koptur and D. Lee for comments on early drafts. The research described in this paper has been funded in part by the United States Environmental Protection Agency (EPA) under the Science to Achieve Results (STAR) Graduate Fellowship Program, Florida International University's Presidential Enhancement Award, and the National Geographic Society Conservation Trust (C61-05). This publication is not officially endorsed by EPA and may not reflect the views of the agency. 


\section{LIST OF REFERENCES}

BESKOKOTOV, Yu. A. 1996. The cadastre of insects of Aksu-Jabagly Nature Reservation. Procceedings of Aksu-Jabagly Nature Reservation, Vol. 7. Almaty. pp. 103-194. (in Russian)

CARPENTER, C., FET, G. AND FET, V. 2001. Tian Shan foothill arid steppe (PA0818). Terrestrial Ecoregions of the World.

http://www.worldwildlife.org/wildworld/profiles/terrestrial/pa/pa0818_full.html Accessed May 22, 2008.

CHELPAKOVA, J. M., AND MILKO, D. A. 2004. The insect biodiversity and some aspects of its conservation in the Ysyk-Kel Territory of Biosphere. "Ysyk-Kol" Territory of Biosphere, 2 (Proceedings of V Issyk-Kul Symposium). Bishkek. pp. 73-76. (in Russian)

ECONET. 2008. Factsheet - Kyrgyzstan, Econet of Kyrgyzstan. http://www.wwf.ru/data/asia/econet_maps/kyrgyzstaneng.doc Accessed May 21, 2008.

KAZENAS, V. L. 2001. Fauna and biology of sand wasps (Hymenoptera, Sphecidae) of Kazakhstan and Middle Asia. Almaty. 334 pp. (in Russian)

KREVER, V., PERELADOVA, O., WILliAMS, M., AND JUNGIUS, H. 1998. Biodiversity conservation in Central Asia: An analaysis of biodiversity and current threats and initial investment portfolio. Wild Fund for Nature (WWF), Moscow. http://www.wwf.ru/resources/publ/book/eng/36 Accessed May 22, 2008.

KURZENKO, N. V. 1995. Supefam. Vespoidea. 65. Fam. Vespidae. Key to the Insects of Russian Far East. Vol. 4, Pt 1. St.-Petersburg. pp. 264-324. (in Russian)

MELDEBEKOV, A. M. 2006. Red Data Book of Almaty Province (Animals). Zoological Institute, Center of Biological Research of the Kazakh Ministry of Education and Science. Almaty, Kazakhstan. 520 pp. (in Russian)

MICHENER, C.D. 2000. The Bees of the World. The Johns Hopkins University Press, Baltimore, MD.

MILKO, D. A. 2006. Sary-Chelek State Biosphere Zapovednik: History of Biological Research, pp. 183-184 IN R. V. Jashenko [ed.] Strict Nature Reserves of Central Asia. Nature Protected Areas of Central Asia, No. 1. Tethys, Almaty, Kazakhstan. 352 pp.

MILKO, D. A., AND MAKOGONOVA, I. V. 1999. To the knowledge of the Hymenopterous insect fauna of clay precipices. Problems of Conservation and Sustainable Use of Animal Biodiversity of Kazakhstan: Procceedings of International Science Conference 6-8.iv.1999, Almaty. Almaty. pp. 137-139. (in Russian) 
OSYTSHNJUK, A. Z. 1995. 69. Family Andrenidae. Key to the Insects of Russian Far East. Vol. 4, Pt. 1. St.-Petersburg. pp. 489-527. (in Russian)

PANFILOV, D. V. 1962. Peculiarities of biocenotic structure and geographical distribution of insect fauna in Issyk-Kul Region. Investigation on Geography of Natural Resources of the Animal and Plant World. Moscow. pp. 164-198. (in Russian)

POPOV, V. V. 1962. Bees of the subgenus Megalosmia Schmied. (Hymenoptera, Megachilidae). Proceedings. of the Zoological Institute, Kazakh SSR, Vol. 18. AlmaAta. pp. 155-162. (in Russian)

SHUKUROV, E. D. AND TARBINSKY, Yu. S. 1996. Genetical Fund Cadastre of Kyrghyzstan. Vol. 3. Superclassis Hexapoda (Entognatha and Insecta). Aleine, Bishkek. 406 pp. (in Russian)

SURAPPAEVA, V. M., AND MILKO, D. A. 2006. Issyk-Kul State Zapovednik, pp. 134-147 IN R. V. Jashenko [ed.] Strict Nature Reserves of Central Asia. Nature Protected Areas of Central Asia, No. 1. Tethys, Almaty, Kazakhstan. 352 pp. 


\title{
CHAPTER VI
}

\section{HOME GARDEN DEVELOPMENT INITIATIVE IMPROVES MANAGEMENT}

\section{PRACTICES}

\begin{abstract}
In 2007, and international development organization in partnership with a microfinance institution implemented a home garden development initiative blending ethnoecological and agroecological approaches using low technology-low input techniques appropriate for local agroecosystems to improve horticultural and home garden management practices. Its aim was to improve the effectiveness of these practices and increase the income earning potential of low-income households in northeastern Kyrgyzstan. In late 2007, pre-initiative and in late 2008, post-initiative, a cohort of 602 households, both participants in the development initiative and non-participants, were surveyed from eight villages to evaluate adoption rates and changes in income. Both pre- and post-surveys showed that home gardens are important sources of income for households. Results indicated that there were significant rates of adoption for nearly all techniques among both participants and non-participants indicating diffusion of knowledge beyond the direct beneficiaries, the participants. However, direct participants had higher rates of adoption than non-participants of management practices that impact long-term yield, and thus income, sustainability and stability such as composting, thinning of fruits, grafting and seedling establishment. The research team found a direct link between the adoption of management techniques and increased income. Targeting home gardens for
\end{abstract}


agricultural development initiatives based on prior ethnoecological research and agroecological principles improves management practices and household income.

Key Words:

Agricultural Extension, Agroecology, Ethnoecology, Home garden, Kyrgyz Republic

\section{Introduction}

\subsection{Agricultural Extension and Home Gardens}

Agricultural extension targeting small-scale farmers can increase incomes and agricultural yields for rural households in developing countries, thereby improving food security for many poor families (Altieri, 2002, Hazell et al., 2007, Kompanion, 2008, Mazvimavi and Twomlow, 2009). Small-scale farms, or home gardens, contribute significantly to agricultural production throughout the former Soviet Union (FSU) accounting for between $25-60 \%$ of the total agricultural output in countries such as Russia, Uzbekistan, and Moldova (Seeth et al., 1998, Lerman, 2006, Lerman, 2008, Sharashkin, 2008). Home gardens are small agro-forestry systems with a mixture of cultivated trees, shrubs, and herbs in the area surrounding a household maintained and managed by those in the household (Fernandes and Nair, 1986). Home gardening and subsistence agriculture in Russia played an important role in mitigating poverty, income generation, and food consumption in the years following the collapse of the FSU (Seeth et al., 1998, Pallot and Nefedova, 2003). In Kyrgyzstan, a country of more than 5.2 million with a $40 \%$ poverty rate in 2006 (ADB, 2008), home gardens in 2007 accounted for $22 \%$ of the total agriculture output (in tons) and 27\% in Kyrgyz som value (NSC 
2008). There are more than 725,000 home gardens in Kyrgyzstan, averaging 0.14 ha, which produce apple, apricot, pear, plum, currant, potato, tomato, cucumber, onion, garlic, and other temperate crops (World Bank, 2005, Currey, 2007, NCS 2008). In $2007,77 \%$ of Kyrgyzstan's fruits and berries, $28 \%$ of potatoes, $52 \%$ of vegetables and $9 \%$ of grains were grown in home gardens (NSC 2008). Despite these yields, and the fact that over $90 \%$ of rural households realize yields from their home gardens, food insecurity continues to be a serious issue in Kyrgyzstan with $34 \%$ of population food insecure as of September 2008 (Dhur, 2009).

Despite their small size, home gardens in former Soviet Republics produce more than subsistence needs; many produce market products (Lerman, 2008, Lerman, 2006, Pallot and Nefedova 2003, Seeth et al., 1998, Lerman et al., 1994). From 1966-1987, in the Soviet Union, $20-30 \%$ of yields from home gardens were sold while the rest was consumed by the household, gifted, or fed to livestock (Lerman et al., 1994). As Seeth and co-authors (1998) found in Russia, increasing yields from small-scale agricultural plots, such as home gardens, provided a buffer for households against food insecurity and rural poverty; there is great potential for rapidly increasing self-sufficiency of households and creating sources of income in Kyrgyzstan. First steps suggested to improve incomes for home gardeners include: (1) more marketing and improved market linkages for home garden production (Lerman, 2006, Pallot and Nefedova, 2003, Wegren, 2004, Lerman et al., 1994); (2) increased plot size (Lerman, 2006); and (3) access to credit (Lerman, 2006, Wegren, 2004). 
Capital intensive technologies aimed at increasing agricultural productivity, such as the development of new varieties, irrigation expansion and chemical inputs are out of reach for many small farmers or have negative environmental effects (Tilman, 1999, Altieri, 2002, Naylor and Falcon, 2008, Norris, 2008). As world population grows and the impacts of climate change on agriculture become more apparent, there is a greater need to feed the hungry equitably by improving production yields sustainably without contributing to land degradation (Lobell et al., 2008). Small-scale farmers such as home gardeners in Kyrgyzstan, whose food security and livelihoods depend on their own agricultural production, are receptive to agricultural extension and other agricultural development activities that provide access to capital and information that complements their knowledge base (Altieri, 2002, Swinton and Quiroz, 2003). Targeting home gardens in Kyrgyzstan and other republics of the former Soviet Union with low external input technology (LEIT) agricultural production based on agroecological principles is a valuable way to improve agricultural practices and increase the efficiency of available lands (Altieri, 2002, Pretty et al., 2003). This has the potential to provide both food security for the household and supplemental income.

Low external input technology is an important concept for development initiatives targeting poor farmers in rural areas. According to Robert Tripp (2006), LEIT is a range of technologies used in basic agricultural extension and information dissemination that "feature the use of local inputs and resources, consider long-run environmental consequences as well as short-run production gains" and targets adaptation at the farmerlevel as opposed to top-down recommendations. The elimination of external inputs, such 
as pesticides and chemical fertilizers, and their substitution with organic and mineral fertilizers is a focus of LEIT. Low external input technology techniques are not entirely restricted to resources available on the farm; many LEIT farmers use biopreparations to control pests and seeds and tools, which are purchased off of the farm (Tripp, 2006). However, the focus of LEIT is on integrating improved agricultural techniques into current practice to increase the sustainability of agriculture for farmers. To deliver extension effectively, farmers must be provided with information, technology and incentives for adoption in a timely manner. One of the challenges of applying the LEIT agricultural extension model to home gardens is reaching hundreds of thousands of home gardens in a cost-effective manner. Though more labor and knowledge intensive than traditional extension services, LEIT but can be integrated into different agricultural development models. (Picciotto and Anderson, 1997, Sharma, 2002, Anderson and Feder, 2004). However, the most critical challenge is ensuring the most appropriate techniques are selected to focus development initiatives upon and that these techniques are identified based on an understanding of local knowledge, current land management practices, localized environmental conditions, the economic role of agricultural production for households and market pressures (Nazarea, 1999, Altieri, 2002).

This paper examines adoption of LEIT techniques delivered through extension and family income improvement among small-scale farmers, home gardeners, during one such agricultural development initiative in the Kyrgyz Republic. LEIT techniques were selected using integrated ethnoecological and agroecological development approaches (Nazarea 1999, Altieri, 2002) and for appropriateness to small home gardens (average 
size 0.1 ha. in Kyrgyzstan) and the lack of disposable income for inputs (Dhur, 2009). Targeting home gardens with the goal of increasing agricultural production enables rural Kyrgyz farmers to improve their food security and also provides additional income for household needs. Due to the importance of home gardens to Kyrgyzstan's agricultural sector and the value of home gardens as a first response to improving food security, home gardens have great potential as a focus for agricultural development initiatives.

This paper evaluates the economic benefits and adoption of horticultural methods that have the potential to improve agricultural production in the long-term for home gardeners. I describe the role of home gardens in Kyrgyz agriculture and the ethnoecological and agroecological development approaches using LEIT as implemented by Mercy Corps and Kompanion through the 2007-2008 "Gardens and Plastics" home garden development initiative. Based on two extensive surveys (602 interview respondents; pre- and post- implementation), I report and compare adoption rates of critical horticultural practices and income from home gardens and other agricultural activities among participants and non-participants and demonstrate that the adoption rates of both project participants and non-participants improved, indicating a diffusion of information within the community. Improved management techniques are known to be associated with higher incomes and this is evaluated in targeted communities. I show that placing a focus on small-scale agriculture has profound impacts on incomes and adoption of improved practices in home gardens diffuses to other households in the community with essential, complementary activities such as community mobilization, marketing, and access to credit critical to the success of agricultural extension initiatives. 


\subsection{Home Garden Production in Kyrgyzstan}

The Kyrgyz Republic suffered swift economic collapse after the fall of the Soviet Union and it has been slow to recover in the intervening 18 years (Pomfret, 1995). The country is predominately mountainous and hosts a complex terrain with a variety of natural ecosystems (Shkurov et al., 2007). The population of Kyrgyzstan is well educated; the adult literacy rate is $99.3 \%$ (ADB, 2008). Unemployment was approximately $8.3 \%$ in 2006, the highest in the former Soviet countries of Central Asia (ADB, 2008). The population is approximately $65 \%$ rural and many rely on agriculture for their livelihood (ADB, 2008). Kyrgyzstan has an area of nearly 20 million ha, of that approximately 1.4 million ha, or seven percent, of the total is suitable for agriculture (this includes arable land, fallows and hayfields) (Shkurov et al., 2007) and over 40\% is degraded (Kyrgyzstan Delegation, 2007). The agricultural sector employs $65 \%$ of total workers (however, the Asian Development Bank estimates agricultural employment at 48\%) and contributes one-third of GDP added value (GKR, 2006). Kyrgyzstan's 726,632 home gardens contributed $22 \%$ of the total agricultural production in 2007 (NSC, 2008), a smaller contribution than the $60 \%$ contribution in Uzbekistan in 2007 (Lerman, 2008) and the $54 \%$ of total agricultural output (in ruble value) from home gardens in Russia in 2002 (Wegren, 2004), but still a substantial source of production. Despite its large contribution to national GDP, there are only 101,200 hectares of home gardens in Kyrgyzstan, or 9\% of the area under cultivation in 2007 (NSC, 2008).

Agricultural development has had a short and unique history. During the process of collectivization beginning in the 1930s, the traditionally semi-nomadic people of 
Kyrgyzstan were permanently settled, which resulted in widespread poverty for herders unused to agriculture (Schmidt and Sagynbekova, 2008). After the collapse of the Soviet Union in 1991, all collective assets were divided and distributed to former employees of state and collective farms, who suddenly found themselves individual farmers. Many farmers employed on collectives had specialty training and had only performed one aspect of work on the farm. Rural Kyrgyz citizens were left with small plots of land, but little or no experience in planning crops, caring for their farm, or marketing and selling any excess produce (Messerli et al., 2006, 458).

Across the Soviet Union, individuals grew their own food and supplemented their income with small home garden plots (Lerman et al., 1994, Pallot and Nefedova, 2003), which have a long history in Russia and remain widespread across the former Soviet Union, despite being constrained during the Soviet period (Seeth et al., 1998). The original impetus for the establishment of home gardens in the former Soviet Union, Kyrgyzstan included, was to ensure that rural residents produced their own food at the household level to help cope with shortages without having to develop food distribution networks that were established for supplying cities with food (Lerman et al., 1994, Pallot and Nefedova, 2003). Throughout the Soviet period, policies vacillated between support and opposition of home gardens, finally becoming more permissive under Premiers Brezhnev and Gorbachev as part of wider agricultural and economic reforms undertaken by the state (Wegren, 2004). However, home gardens have always been subsidized by collective farms. These subsidies included inputs and services (Lerman et al., 1994, Van Atta, 1998). Each country of the former Soviet Union crafted different land reform and 
distribution policies resulting in differences in the predominance of collective farms, private farms, and household plots, or home gardens (Lerman, 2006). In Kyrgyzstan, privatization of land has provided more that 725,000 rural households the opportunity to operate a home garden either for family consumption or sale (NSC, 2008).

\section{Materials and Methods}

\subsection{Development Initiative Description}

The Gardens and Plastics (GAP) home garden development initiative was a community mobilization and technical assistance project aiming to improve household income through improved apple crop production and marketing of that production. GAP activities focused on organic fruit production, yield and home garden improvement, community mobilization, and marketing (Kompanion, 2008). GAP was implemented by Mercy Corps Kyrgyzstan and the Development Initiatives and Technical Support Unit staff of Kompanion, a community development microfinance institution founded by Mercy Corps in 2004. From August 2007 to February 2009, the project sought to improve apple yields and incomes with a participatory education strategy including agricultural and business skill development as well as improving market linkages. The development initiative used group methods, social learning, farmer participation and farmer led extension in addition to improving access to credit and facilitating market linkages.

Open enrollment was offered for one thousand spaces and interested households were registered ("participants") although multiple individuals from each household could 
attend trainings. Participants provided informed consent for interviews, access to their gardens and additional information concerning yields and sales of fruits. Participants were divided into 42 groups of approximately 24 people each according to geographic proximity, who regularly attended trainings on agricultural practices led by an agronomist. Groups gathered with a staff agronomist in participants' gardens and utilized a participatory education method in which participants were encouraged to experiment with the practices being taught and discuss the practice together and with their neighbors. A single agronomist and a community mobilizer remained with each group for the duration of the initiative and conducted each training with the group. Trainings were scheduled such that the practices taught in the seminar could be immediately applied to the individuals' home garden. No inputs were provided to households, but, as an incentive for households to invest in their future home garden production, participant households were offered a discounted loan rate, though this was not advertised prior to the voluntary registration period.

The selection of management practices were based on ethnoecological, agroecological and LEIT approaches (Altieri, 1995, Nazarea 1999, Tripp, 2006). Selected management practices were those that were already being used by households (Table 4; Appendix 4), thus respecting traditional and local knowledge, but recognizing that not all techniques used by rural home gardeners were effective and that modifications to these practices in accordance with agroecological principles could improve the productivity of home garden agroecosystems (Altieri, 2002, Altieri, 2004). For example, nearly all households pruned fruit trees, but not aggressively enough to be effective for fruit quality (color) 
improvement, to prevent branch breakage when heavy with fruits, or for good intercrop yields due to low light availability. Composting and thinning of fruits were practiced by only some households, but this indicated that households would be receptive to testing the practices. Currey also conducted in-depth socio-economic, ecological, entomological, and ethnoecological research in these communities with broad community participation over a three year period before the development initiative began, ensuring household needs were taken into full consideration (Currey, unpublished data).

Management techniques included those that enhanced biomass and nutrient availability and cycling, soil organic matter for improved plant growth and beneficial biological interactions including species and varietal diversity of insects, animals, and plants (Altieri, 2002) (Appendix 4). Other techniques optimize solar radiation, water and nutrient use. Trainings focused on seven LEIT management practices pertinent to apple tree cultivation in home gardens due to the importance of apple sales for income and the importance of home gardens for in situ conservation of apple varieties (Dzhangaliev et al., 2003, Currey, 2007). Management practices included those that: 1) impact short-term yield improvements while also enhancing beneficial biological interactions and optimizing solar radiation (pruning, thinning and biological pest control); 2) improve long term sustainability of soil quality by improving biomass and nutrient availability (organic fertilizer use and composting), a significant issue for smallholder farms (Swinton and Quiroz, 2003, Zingore et al., 2009); and 3) ensure future yields while maintaining agrobiodiversity (grafting and sapling selection and establishment) (Tripp, 2006). Additional training topics that are not analyzed here included: pollination; winter 
care of fruit trees; yield prognosis; harvesting, sorting, and grading; storage; home budgeting; marketing skills; and negotiation skills. Cross-cutting themes for all trainings included water, soil, and agrobiodiversity conservation and management.

An assumption made in the design of the initiative, which is supported by published studies, is that poorer, small-scale farmers are more likely to adopt low-input techniques that draw on locally available resources and skills (Altieri, 1995, Altieri, 2002, Swinton and Quiroz, 2003, Tripp, 2006) and that providing additional information that complements home gardeners' knowledge base improves natural resource management practices (Swinton and Quiroz, 2003). This is more likely when there are strong community structures, either existing or created through mobilization activities, which can support land stewardship and facilitate the diffusion of practice and knowledge within and among communities (Swinton and Quiroz, 2003).

\subsection{Study Site}

The Gardens and Plastics home garden development initiative was implemented in eight villages along the southern shore of Lake Issyk-kul in northeast Kyrgyzstan. Lake Issykkul, the second largest high elevation lake in the world, is located at 1,650 meters above sea level and is surrounded by the Tien Shan mountains with peaks ranging from 4,000 to 5,200 meters (Ter-Ghazaryan and Heinen, 2006). The Issyk-kul basin consists of three cities, 400 inhabited areas, and 420,000 people (Kojekov, 2008). Participants were from villages in Ton and Djeti-Oguz regions: Tort-Kul, Kyzyl-Too, Karakoo, Kara-Talaa, Tosor, Tamga, Barskoon and Darkhan. The majority of households in these villages are 
ethnic Kyrgyz. The villages have an average size of 1,043 households and households consist of five people, on average. The average size of studied home gardens is $0.2 \mathrm{ha}$, similar in size to home gardens in Turkmenistan ( $0.2 \mathrm{ha})$ and Uzbekistan ( $0.17 \mathrm{ha})$, but smaller than Russian home gardens (0.4 ha) (Wegren, 2004, Lerman and Stanchin, 2004, Lerman, 2008). Gardens in this region were founded in the 1960s and 70s for the most part, although there were some founded in the early 1900's (Currey, unpublished interviews). Households grow apple, apricot, pear and plum trees; currant and raspberry shrubs; and also vegetables, such as potato, tomato, cabbage, cucumber, squash and carrots as well as herbs and grasses. In each of the studied villages, $90-100 \%$ of residents engage in some form of agriculture. Other formal employment opportunities are limited and include teaching, government positions, and industry (including a gold mine). Reported agricultural challenges include reduced soil fertility and lack of crop rotation (Kojekov, 2008).

\subsection{Household Surveys}

A stratified (by village and among participants and non-participants) random sample of 650 households in the targeted villages were interviewed with a structured questionnaire. Analyses include 602 households, of which 335 were non-participants and 267 were participants that were interviewed in 2007 and 2008. "Participants" are residents who enrolled in the GAP horticultural development initiative during open enrollment; "nonparticipants" are other residents in the communities where GAP was implemented, but did not enroll. Questions pertained to household demographics, income, sources of income, as well as agricultural, horticultural, business, and conservation practices. The 
pre-implementation surveys were conducted in December 2007 and January 2008 and the post-implementation surveys were conducted in December 2008. Ten village residents, primarily math and science teachers, were trained and interviewed respondents in their own communities. Demographic differences between participants and non-participants were tested using two-sample t-tests for comparing means and two-sample z-tests for comparing proportions.

\subsection{Land Management and Horticultural Practices}

To compare extent of use of the seven different horticultural and land management practices between participants and non-participants both before (2007) and after (2008) trainings, I performed two-sample z-tests for equality of two proportions using pooled estimates for each of the seven management practices, separately. This analysis gives identical results to the chi-squared test statistic for 2 x 2 contingency tables for independence of population proportions (Agresti and Finlay, 1997). I tested the effectiveness of horticultural extension for participants and non-participants separately using the McNemar test for symmetry to compare dependent proportions to examine adoption of each of the seven management practices between 2007 and 2008 (Agresti and Finlay, 1997). The McNemar test takes into account that samples for these analyses are dependent since the same households that were randomly selected in 2007 were reinterviewed in 2008 . 


\subsection{Income and Management Practices}

To compare participant and non-participant households in 2007 and after trainings in 2008, I used two-sample t-tests on the following income variables, separately: total income; income from the sale of apples; income from home gardens; income from other agricultural lands (not home gardens); income from livestock activities (sum of income from: livestock, meat, milk, wool, eggs, small animals and poultry) and formal employment (sum of salaries and wages). I used paired t-tests for each of the six income categories to determine if there were significant changes among participants and nonparticipants between 2007 and 2008 in income. Additionally, I compared the proportion of households living below the poverty line between participants and non-participants both before and after the development initiative using two-sample z-tests for equality of two proportions using pooled estimates I also tested participants and non-participants separately to determine if there were changes in the proportion of households living above and below the official poverty line for Kyrgyzstan using the McNemar test for symmetry to compare dependent proportions between 2007 and 2008 (Agresti and Finlay, 1997). Though actual data are reported in Tables 3 and 4, income data were square root transformed and strong outliers greater than three standard deviations from the mean were removed for statistical analyses (McCune and Grace, 2002). The majority of outliers were unique households with income earning opportunities unlike the rest of households such as employment at a foreign-owned mine, leasing agreements for harvesting fruits on government owned orchards, substantially larger land holdings, or very successful small business, all of which are not the norm in these communities. 
To determine if adoption of each of the different land management practices was associated with increases in income from home gardens and the sale of apples, I performed simple linear regression analyses using square-root transformed income variables with outliers removed as the response variables. Statistical analyses were preformed using SPSS version 16 (SPSS Inc., 2007) and SYSTAT version 12 (SYSTAT Inc., 2008). Means are reported in the text as mean \pm one standard deviation.

\section{Results and Discussion}

\subsection{Household Characteristics}

Surveyed households comprised 4.9 members, on average, with an average of $2.0 \pm 1.4$ minors per household (Table 1). Respondents were equally likely to be male or female ( $49 \%$ female), were predominately married ( $83 \%$ ) and had an average age of $46.5 \pm 13.7$

years (Table 1). There were no significant demographic differences between respondents from households that voluntarily enrolled in the agricultural development initiative and those who did not, other than age (two-sample t-test $\mathrm{p}=0.020$ ). Respondents from households that participated in the development initiative were slightly younger (45.1 \pm 12.30) than those who did not (47.6 \pm 14.56$)$.

\subsubsection{Changes in income sources}

The average total income for all households surveyed in 2007 was $64,058.52 \pm 64,588.88$ Kyrgyz som $(\$ 1 \mathrm{USD}=37.75 \mathrm{KGS})$ and increased to $67,928.10 \pm 64,785.57$ in $2008(\$ 1$ $\mathrm{USD}=36.11 \mathrm{KGS})(\mathrm{CIA}, 2009)$. As of December 2007, the poverty line in Kyrgyzstan was 11,557.7 KGS per capita per year (NSC, 2008b). Like other research concerning 
home gardens, agricultural extension and poverty (Seeth et. al., 1998, Swinton and Quiroz, 2003, Mazvimavi and Twomlow, 2009), more than half $(0.58 \pm 0.49)$ of respondents were below the poverty line. As in Russia, households earn income from numerous different sources and this diversification of income sources was found to have increased in importance since transition (Seeth et al., 1998). There were differences between those who participated in the development initiative (Participants; Table 2) and those who did not (Non-participants; Table 3), so further results will be reported separately for both groups.

In 2007, pre-initiative, $78 \%$ of participants earned income from their home gardens and home gardens were only second to salary $(33 \%)$ for average contribution to total income $(17 \%)$ (Table 2). This is a higher frequency than the $66 \%$ that Seeth and co-authors (1998) documented in Russia, the 60\% in Ukraine and Moldova (Lerman, 2006), and approximately the same as in Belarus (Lerman, 2006) but less than in Nicaragua (70\%) (Mendez et al., 2001). The frequencies of other sources of income for participants in 2007 are as follows: pensions and social benefits (50\% of households); salaries $(50 \%)$; livestock (45\%); agricultural income other than home gardens (40\%); animal products such as wool, milk, and eggs (33\%); businesses (23\%); wages (22\%); support from relatives and gifts (20\%); and small animals, such as poultry and rabbits (3\%). For nonparticipants, home gardens were slightly less important in 2007 with $73 \%$ of nonparticipant households earning, on average, $13 \%$ of income from their home gardens (Table 3). Pensions and other social benefits (50\%) and salaries (48\%) were the other most frequent sources of income for households followed by: livestock (44\%); other 
agricultural land (36\%); businesses (27\%); wages (26\%); animal products (25\%); relatives and gifts (20\%); and small animals and poultry $(6 \%)$. Since participation in the development initiative was voluntary and determined through an open registration process, it is logical that more participant households would have had income earnings from home gardens and fewer with formal employment.

The prevalence of different income sources changed from 2007 to 2008 among both participants and non-participants. Most notably, a smaller number of participant households earned income from their home gardens (43\%), but the average contribution of home gardens to total income among all participant households remained unchanged $(18 \%)$ (Table 2). This may be due to other aspects of the development initiative that encouraged households to consider their food needs when deciding whether or not to sell their production and also a major hail storm that affected three of the eight communities just prior to apricot harvest severely damaging the apricot, pear and apple crops, which are important home garden cash crops. However, those who sold their production earned more, an average, in 2008 than in 2007. The frequencies of other sources of income for participants in 2008 were similar to 2007: pensions and social benefits (55\% of households); livestock (53\%); salaries (43\%); agricultural income other than home gardens (38\%); animal products such as wool, milk, and eggs (32\%); wages (24\%); businesses (15\%); support from relatives and gifts (24\%); and small animals, such as poultry and rabbits $(6 \%)$. For non-participants in 2008 , home gardens were also slightly less prevalent as a source of income in 2008 (66\%), but households earned, on average, a higher percentage of their income from home gardens than in 2007 (17\%) (Table 3). 
Pensions and other social benefits (53\%) and livestock (49\%) were the other most frequent sources of income for households. The prevalence of salaried jobs decreased slightly (43\%), perhaps explaining why more non-participant households earned income from home gardens, reinforcing the role of home gardens as a safety net for households (Pallot and Nefedova, 2003, Seeth et al., 1998). Thirty-five percent of households earned income from agricultural land other than home gardens; $28 \%$ from the sale of milk and other animal products; $25 \%$ received support from friends and relatives; and $24 \%$ earned wages. There was a $15 \%$ drop in the number of non-participant households earning income from small businesses (12\%) and small animals and poultry were a source of income for only $4 \%$ of households since most households raise them for their own consumption.

\subsubsection{Changes in income}

For total household income and each of the five different sources of income, there were few differences between participants and non-participants pre-intervention (Tables 2 and 3). In 2007, total household income did not differ significantly between participant $(62,294.2 \pm 61,346.62)$ and non-participant households $(65,464.7 \pm 67,118.76)$ (twosample t-test; ns), nor were there significant differences in the proportion of participants and non-participants living below the poverty line (participants: $0.57 \pm 0.50$; nonparticipants $0.59 \pm 0.49$; z-test; ns). Income from livestock (livestock, meat, milk, eggs and other animal products, as well as poultry), employment income (salaries and wages), income from home gardens, and income from other agricultural lands did not differ significantly between participants and non-participants in 2007 (two-sample t-test; ns). 
On average, interviewed households in 2007 earned $41 \%$ of their income from formal employment (salaries and wages), similar to the $37 \%$ reported for Uzbek households (Lerman, 2008), 18\% from livestock, and 21\% from home gardens and larger scale agriculture, combined. The only difference was that participants earned significantly more income from the sales of apples $(5,133.0 \pm 7,654.38)$ than non-participants $(3,522.2$ $\pm 6,328.77$ ) before the agricultural development initiative (two-sample test; $t_{d f=596}=3.64$; $\mathrm{p}<0.001$ ) (Tables 2 and 3). Following the development initiative in the eight communities in 2008 , there were no significant differences in total income, income from apples, home gardens, other agricultural lands, livestock, formal employment or proportion of households living below the poverty line between participant and nonparticipant households (Tables 2 and 3).

There were, however, some critical differences in income among participant and nonparticipant households before and after implementation of the agricultural development initiative. For participants, total income and income from four of five sources significantly increased from 2007 to 2008 (home gardens; paired t-test, $\mathrm{t}_{\mathrm{df}=253}=11.04, \mathrm{p}<$ 0.001; apples, $\mathrm{t}_{\mathrm{df}=258}=7.77, \mathrm{p}<0.001$; livestock, $\mathrm{t}_{\mathrm{df}=253}=3.41, \mathrm{p}=0.001$ and formal employment, $\mathrm{t}_{\mathrm{df}=252}=21.96, \mathrm{p}<0.001$ ) (Table 2). For non-participants, total household income (paired t-test; ; $\mathrm{t}_{\mathrm{df}=317}=31.59, \mathrm{p}<0.001$ ) and income from formal employment (paired t-test; ; $\mathrm{t}_{\mathrm{df}=318}=20.67, \mathrm{p}<0.001$ ) significantly decreased, while the other four sources increased (home gardens, $\mathrm{t}_{\mathrm{df}=326}=9.44$, apple sales, $\mathrm{t}_{\mathrm{df}=330}=10.01$, large-scale agriculture, $\mathrm{t}_{\mathrm{df}=328}=10.02$, and livestock, $\mathrm{t}_{\mathrm{df}=323}=4.25$; all paired $\mathrm{t}$-test; all $\mathrm{p}<0.001$ ) (Table 3). Participant households' total income significantly increased by 10,660.5 KGS, 
or $17 \%$, (paired t-test; $t_{d f=253}=26.86, p<0.001$ ) while non-participant household's total income decreased significantly by $1542.8 \mathrm{KGS}$, or $2 \%$ (paired $\mathrm{t}$-test; $\mathrm{t}_{\mathrm{df}=317}=31.59, \mathrm{p}<$ 0.001). Income from formal employment had the same trend; participant households' income from employment increased by $11 \%\left(2,612.4 \mathrm{KGS}\right.$; paired $\mathrm{t}$-test; $\mathrm{t}_{\mathrm{df}=252}=21.96, \mathrm{p}$ $<0.001)$ while non-participants' decreased by $23 \%\left(6671.9\right.$ KGS; paired t-test; $t_{d f=318}=$ 20.67, $\mathrm{p}<0.001)$. When outliers were controlled for, income from larger-scale agriculture also decreased slightly for participants $\left(1 \%\right.$, or $36 \mathrm{KGS}$; paired $\mathrm{t}$-test; $\mathrm{t}_{\mathrm{df}=258}=$ $8.42, \mathrm{p}<0.001$ ) while non-participants' income from other agriculture increased significantly $\left(20 \%, 573.1 \mathrm{KGS}\right.$; paired t-test; $\left.\mathrm{t}_{\mathrm{df}=328}=10.02, \mathrm{p}<0.001\right)$.

\subsubsection{Home garden and apple sale income}

Home gardens and apple sales, the focus of development initiative activities, were important sources of income for both participant and non-participant households in both 2007 and 2008. For participants, home gardens accounted for, on average 17\% of total income, and while income from home gardens significantly increased following the development initiative $\left(2518.6 \mathrm{KGS} ; 24 \%\right.$; paired $\mathrm{t}$-test; $\left.\mathrm{t}_{\mathrm{df}=253}=11.04, \mathrm{p}<0.001\right)$, the contribution of home gardens to total income remained nearly the same at $18 \%$. This is a much lower proportion of home gardens contributing to total income than documented in other newly independent republics. In Uzbekistan, home gardens accounted for $26 \%$ of total income (Lerman, 2008), in Turkmenistan, 36\% (Lerman and Stanchin, 2004) and in the Ukraine in 1997, 53\% (Van Atta, 1998). Larger scale agriculture accounted for only $8 \%$ of total income in both 2007 and 2008 . This could be due to the distance of larger plots from the villages; they are located on the outskirts of the villages and transport is 
limited. Seeth and co-authors (1998) found that distance was an important limiting factor to income from agricultural production. Theft of agricultural production is well known and a serious issue for growers. Larger plots in this region are overwhelmingly planted in potato for use by the family and fetch much lower prices than high-market value fruit from home gardens. In contrast, home gardens became more important for nonparticipant households as income from formal employment decreased, accounting for $13 \%$ of total income in 2007 and increasing to $17 \%$ in 2008. Non-participants also earned significantly more income from home gardens following activities associated with the development initiative (2373.5 KGS; $28 \%$ increase; paired t-test; $\mathrm{t}_{\mathrm{df}=326}=9.44, \mathrm{p}<$ 0.001). Larger scale agriculture was similarly less important for non-participant households both before ( $6 \%$ of total income) and after development activities in 2008 $(6 \%)$.

Income from sales of apples grown in home gardens was more important than largerscale agriculture for participants in both 2007 and 2008 and non-participants in 2008, following development initiative activities (Tables 2 and 3). Both participants and nonparticipants earned significantly more income from the sales of their apples between 2007 and 2008 (paired t-test; $\mathrm{p}<0.001$ for both participants and non-participants). The development initiative focused on finding buyers for fruits in all sectors of the market, marketing communities' fruits, establishing collective bargaining groups within each village and also encouraging intra-village communication for a better bargaining position with buyers. A result of these efforts was the communities' establishment of an association of home gardeners who facilitated the sale of 2000 tons of fruit in 2008 with a 
market value of approximately $\$ 1.3$ million (Kompanion, 2008b). These sales included not only those formally registered for the development initiative (participants), but also other households in the communities (non-participants).

\subsection{Adoption of Management Practices: Participants and Non-Participants}

Households make decisions whether or not to adopt practices and the extent to which practices will be used in their home gardens (Mazvimavi and Twomlow, 2009). For each of the seven land management and horticultural practices examined, there was considerable variability among participants and non-participants in the portion of households who performed these practices before the development initiative and, like other studies have found, variable rates of adoption post-development initiative (Mazimavi and Twomlow, 2009) (Tables 4 and 5). Final evaluation of households showed that, on average, households used $4.14 \pm 1.78$ of the seven practices, or $59 \%$, and participants adopted significantly more practices $(4.51 \pm 1.65)$ than non-participants $(3.85$ \pm 1.83 ) (Mann-Whitney $U ; \chi^{2}$ approximation $\left.=19.90 ; p<0.001\right)$. Pruning and use of organic fertilizers, almost exclusively manure, were the most wide-spread practices for both participants and non-participants both pre- and post-intervention. Pre-intervention, the following practices were performed by over $50 \%$ of participants: pruning $(85 \%)$, organic fertilizer (82\%), and grafting (67\%). Non-participants were similar: $81 \%$ used organic fertilizers, pruned $(80 \%)$, and grafted $(63 \%)$. There were only slight differences in the proportion of households applying the seven different management practices between those who chose to enroll in the project (participants) and those who did not (non-participants) pre-intervention; significantly more participant households thinned 
fruit trees $(8 \%$; z-test $p=0.046)$ and used beneficial insects or other biological methods for pest control ( $7 \%$; z-test $\mathrm{p}=0.031)($ Table 4$)$. Post-intervention, these differences increased. The extent of use of different management practices was significantly higher for participants than non-participants for: grafting $(9 \% ; \mathrm{p}=0.019)$; thinning $(11 \% ; \mathrm{p}=$ 0.006), as was also the case before the trainings; and composting $(20 \%$; $<<0.001)$ (Table 4). Significantly fewer non-participant households purchased saplings than participants (-9\%; z-test $\mathrm{p}=0.016)$. Over $40 \%$ of participants (more that 400 households) chose to take microloans for the purchase of saplings and predatory wasps, perhaps explaining this difference, though the authors do not have information about the percent of nonparticipants who may have also used credit for sapling purchase. It is plausible that there were differences between participants and non-participants post-intervention in the extent of pruning $(6 \% ; p=0.051)$ and the use of beneficial insects and other biological control of pests $(8 \% ; p=0.058)($ Table 4$)$. The use of manure and other organic fertilizers continued to be widespread post-intervention and there were no significant differences between participants and non-participants (participants 5\% greater; $\mathrm{p}=0.077$ ).

Rates of adoption increased significantly for both participants and non-participants, but not for all management practices and there were differences in which practices participant and non-participant households adopted (Mazvimavi and Twomlow, 2009) (Tables 4 and 5). Often, farmers do not adopt practices due to insufficient information, risk aversion, size of plots, lack of both input availability and access to credit (Mazvimavi and Twomlow, 2009). Also, the appropriateness of the practice for the household in ecological/socio/cultural context is an important factor in deciding to adopt or not adopt a 
practice (Nazarea 1999, Swinton and Quiroz, 2003, Senthilkumar et al., 2008). Postintervention, five of the six practices were performed by over $50 \%$ of participants: pruning $(91 \% ; 6 \%$ increase; McNemar $\mathrm{p}=0.024)$, organic fertilizer use $(88 \% ; 6 \%$ increase; McNemar $\mathrm{p}=0.042)$, grafting $(72 \% ; 5 \%$ increase; ns), composting $(67 \% ; 35 \%$ increase; McNemar $\mathrm{p}<0.001)$, and thinning $(57 \% ; 20 \%$ increase; McNemar $\mathrm{p}<0.001)$ (Table 4 and 5). The use of biological agents for pest control, primarily Trichogramma wasps, purchased from the Karakol Biological Control Laboratory, increased from $20 \%$ pre- to $36 \%$ post-intervention ( $\mathrm{McNemar} \mathrm{p}<0.001)$. There were significant, positive differences among participant households between 2007 and 2008 for all practices, except for grafting $(5 \%$ increase; McNemar $\mathrm{p}=0.149)$ and the purchase of seedlings, which decreased by $2 \%(\mathrm{McNemar} p=0.783)($ Tables 4 and 5). However, $20 \%$ of participants who had not grafted in 2007, grafted in 2008 and 50\% continued the practice (Table 5). Twenty-two percent of participants purchased seedlings in 2008 who had not the previous year and $18.7 \%$ who had, purchased more (Table 5).

Among non-participants, a larger portion of households performed six of the seven practices, but there were only three of the six practices employed by more than $50 \%$ of households: pruning $(85 \% ; 5 \%$ increase; McNemar $\mathrm{p}=0.036)$, organic fertilizer use $(83 \% ; 2 \%$ increase), and grafting $(63 \%$; no change; McNemar $\mathrm{p}=1.000)$. Though there was a $20 \%$ increase among participants post-intervention for composting ( $47 \%$; McNemar $\mathrm{p}<0.001)$, a $17 \%$ increase in thinning $(46 \%$; McNemar $\mathrm{p}<0.001)$, and a $15 \%$ increase in the use of beneficial insects $(28 \%$; McNemar $\mathrm{p}<0.001)$, overall prevalence of practices were much lower than among participants (Tables 4 and 5). There were no 
significant differences in the proportion of participants using organic fertilizers $($ McNemar $\mathrm{p}=0.318)$ or grafting between 2007 and 2008. There was a significant decrease among participants investing in their future yields as indicated by a $9 \%$ decrease in the purchase of saplings $(\mathrm{McNemar} p=0.014)$ and no change in the proportion of participants grafting Tables 4 and 5).

Participant households had improved access to information, regular contact with staff agronomists, improved access to credit and input suppliers such as the biological control laboratory, as well as the support of their small group; these are all factors that encourage adoption of management practices (Tripp, 2006, Mazvimavi and Twomlow, 2009). Because of this, they may have been less risk-averse and more open to adoption than nonparticipant households, as Mazvimavi and Twomlow (2009) describe them, spontaneous adopters: those who were not the direct participants in the development initiatives but tested some of the techniques that they saw or learned from participants or casual participation in training seminars. This points to one of the challenges for evaluating development initiatives that focus on agricultural extension, LEIT or not. The goal of many development initiatives is to encourage diffusion of information beyond the focal group and many activities, such as establishing market linkages, benefit more than the focal group. This makes it very difficult to establish true control groups, as is the case for this research (Tripp, 2006). However, examining the differences between the groups through a cohort study is one way to control for the issue of trying to determine if households would have adopted the practice had it not been for the development initiative and takes into consideration criticisms of adopter/non-adopter studies (Tripp, 2006). 
Using this approach, a critical finding is a lower proportion of non-participant households adopted practices that are essential for long term sustainability of home gardens including those associated with soil quality such as composting and investing in future yields through grafting and sapling establishment. For short term yields, non-participants were also at a disadvantage as fewer of them thinned, which helps control biennial fruit bearing ensuring yield, for food and income, each year rather than in alternating years. While re-assessment of households in these communities in at least another five years is necessary to further examine adoption and diffusion (or abandonment) (Tripp, 2006), the fact that the development initiative did not subsidize households with free inputs, like some initiatives have (Mazvimavi and Twomlow, 2009), the use of LEIT methods, as well as the high rates of diffusion, I believe households will continue these practices. However, participant households are already in a better position for ensuring future yields than non-participants based on the significant differences between them in trees pruned, grafted, and planted. Additionally, more detailed research is needed to determine the effectiveness in technique for the different management practices of participant and nonparticipant households, and not adoption, alone. Practices that were already in use were targeted for the development initiative due to issues with technique. For example, households were thinning and pruning, but not aggressively enough for optimal effectiveness of thinning to control biennial bearing and improved light penetration from pruning. Households were grafting before the development initiative, but dead-heading trees and using manure to seal tree wounds, reducing the success of the grafts. However, adoption rates are a good indicator of diffusion of knowledge from development initiative staff to the participants and from participants to non-participants. 


\subsection{Horticultural Practices and Income}

Each horticultural practice, except for the purchase of saplings, was modeled separately because of strong multicollinearity to determine how much of the variability in income from home gardens and apple sales was explained by the performance of management practices in 2008, following the development initiative. Whether or not a household participated in the development initiative did not significantly explain variation in income from home gardens $\left(\mathrm{r}^{2}=0.004, \mathrm{p}=0.118\right)$ or apple sales $\left(\mathrm{r}^{2}=0.006, \mathrm{p}=0.072\right)$, most likely the result of other components of the development initiative not analyzed here. Other components of the initiative that impact income from home gardens are those associated with marketing and the number of new buyers who purchased both apricots and apples from households in the community, for participants and non-participants alike. For each individual home gardener with their 0.2 ha of land, the lack of direct contact with buyers (consumer cooperative, exporters, and food processors) is a major obstacle for improving income for home gardeners (Wegren, 2004). Market and distribution networks increase the portion of production that households sell, thus improving income (Lerman, 2008). It is likely that participants and non-participants alike benefited from the introduction of new buyers the development initiative facilitated. Due to these reasons and the significant increases in the use of management techniques that were the subject of demonstrations and trainings among participants and non-participants alike, participant and non-participant households were not separately analyzed for their relationship on income. 
The number of different practices adopted (proportion adoption of package of management practices) did significantly explain the variation in income from home gardens $\left(\mathrm{r}^{2}=0.011, \mathrm{p}=0.010\right)$ and apple sales $\left(\mathrm{r}^{2}=0.017, \mathrm{p}=0.001\right)$, but only $1-2 \%$ for each income variable (Table 6). Pruning $\left(r^{2}=0.039, p<0.001\right)$, grafting $\left(r^{2}=0.017, p=\right.$ $0.002)$ thinning, $\left(r^{2}=0.049, p<0.001\right)$, use of manure and other organic fertilizers $\left(r^{2}=\right.$ $0.044, p<0.001)$ and the use of beneficial insects and other biological methods of control $\left(\mathrm{r}^{2}=0.010, \mathrm{p}=0.016\right)$ significantly explained variation in income from home gardens. Thinning was the only variable negatively correlated with income from home gardens (Pearson $\mathrm{r}=-0.222$; Bartlett Chi-Square; $\mathrm{df}=1 ; \mathrm{p}<0.001$ ). Loss of income due to thinning was expected as the goal of thinning is to decrease the resource burden on the tree during the critical period of bud formation for the following year's yield. The benefit of this is to ensure yields each year rather than having the trees bear biennially, though further research is required to determine if households benefit economically from this. Specifically for apples, the main focus of horticultural trainings, pruning $\left(\mathrm{r}^{2}=0.050, \mathrm{p}<\right.$ $0.001)$, grafting $\left(r^{2}=0.008, p=0.029\right)$, organic fertilizer use $\left(r^{2}=0.014, p=0.004\right)$, use of beneficial insects $\left(r^{2}=0.009, p=0.024\right)$, and composting $\left(r^{2}=0.008, p=0.035\right)$ explained significant portions of the variability in income from apple sales, though only pruning and use of manure explained more than $1 \%$ of the variability in income from apple sales. Grafting was not expected to affect current year income from apple sales or home gardens as it involves the removal of branches from trees and the grafts will not bear fruit for at least another five years. Perhaps the relationship between grafting and income is due to other characteristics of the household that led to that household adopting 
the practice or related to the removal of branches in preparation for grafting, more resembling pruning.

There is a direct link between adoption of pruning, grafting, organic fertilizer use, biological control of pests, and compositing and income from apple sales and home gardens, but there is not a direct link between being a participant in the development initiative and income from apple sales and home gardens. However, total household income for participants significantly increased by 17\% between 2007 and 2008 (Table 2), while total household income for non-participants showed no significant change $(-2 \%)$ (Table 3). Income from home gardens and apple sales, though the target of the development initiative, may not be the best indicator of overall household wellbeing, as participants were encouraged to retain fruit and vegetable yields for their own consumption to improve food security and save money. Many households sell produce that they grow in the fall at low prices when cash is needed, primarily for school clothing and tuition payments, and later buy the same produce when prices are higher. Participants attended trainings on household budgeting and also home storage improvement with the integrated theme of considering their own household consumption needs for planning storage arrangements and before deciding to sell produce.

\section{Conclusion}

The study found that targeting individual households with LEIT management practices for their home gardens with complementary activities such as mobilization, marketing, household budgeting skill building, and improved access to credit is an effective strategy 
for encouraging more households to adopt management practices that may increase longterm productivity of their home gardens based on agroecological principles and improve income. For those households that participated in the development initiative, there were significant rates of adoption for all practices except for grafting, which was already widespread. The study demonstrates a direct link between the adoption of these techniques and income improvement. It also found significant diffusion of knowledge from participants to non-participants with similar income improvements. Using a household approach targeting home gardens appears to affect change beyond the direct beneficiaries. However, there were some critical differences. Participants had higher rates of adoption of management practices that impact long-term yield, and thus income, sustainability and stability of ecological processes than non-participants. Specifically, fewer non-participants composted, thinned, grafted or planted new seedlings. Although there was diffusion from participants to non-participants, participants were more likely to adopt a larger portion of the introduced practices. Among participants and nonparticipants alike, the three practices that were least used by households before the initiative had the highest rates of adoption, but, were overall less prevalent: thinning, pest control and composting. Thinning and pest control have direct effects on stability and marketability of yields and, in the absence of other inputs, compost use is critical to maintaining soil fertility, so new methods for delivery of training should take this into consideration for future development initiatives.

The results show that home gardens are important sources of income for households in Kyrgyzstan, second only to formal salaried positions, and more important than larger 
scale agriculture. Income from the sale of apples from home gardens alone provided households with 33\% more income than they earned from larger scale agriculture. Income from home gardens and the sales of apples increased for both participants and non-participants. Though the results show a relationship between adoption of management practices and increased income from home gardens and apple sales, increased incomes for all households could also be due to the community mobilization and marketing components of the development initiative that improved the communities' ability to attract and work with buyers, resulting in more sales of high-value fruits, especially apples and apricots. However, participants' total income significantly increased and non-participants' decreased, though only by a small margin, suggesting benefits from aspects of the development initiative other than fruit production and sale. Considerable efforts were made to work with existing community structures and to establish new connections within and among communities through intensive work with small groups, usually neighbors, and exchanges, perhaps creating opportunities less available to non-participants. Targeting home gardens for agricultural development initiatives that include mobilization, marketing, and improved access to credit is an effective strategy for poverty reduction and households' adoption of low-technology management practices that influence home garden sustainability.

\section{Acknowledgments}

I would like to thank Miriam Counterman for her collaboration on this paper as well as Daria Toguzbaeva, Nurgul Israilova, Altynai Sagyndykova, Nurjan Eshimov, Mirlan Kashkoroev, and the interviewers of Djeti-Oguz and Ton Rayons for conducting the 
surveys and Kenesh Bukabaev and Omurbek Chynybaev for creating and adapting training modules. The efforts of local village government administrations, Ton and DjetiOguz Rayon Administrations and the Governor and Deputy Governor of Issyk-kul Rayon did much to improve horticulture in the region. Catherine Brown's support is acknowledged and appreciated. I am grateful to Mercy Corps' Phoenix Fund; Mercy Corps' Social Entrepreneurship Fund and the Davidson family; and Kompanion for providing funding for this work. Pilot research conducted by Ms. Currey that contributed to the development of the Gardens and Plastics initiative was supported, in part, by the United States Environmental Protection Agency (EPA) under the Science to Achieve Results (STAR) Graduate Fellowship Program, Florida International University's Presidential Enhancement, and the National Geographic Society Conservation Trust (C61-05). This publication is not officially endorsed by EPA and may not reflect the views of the agency. I thank Suzanne Koptur, David Lee, Mahadev Bhat, Bradley Bennett, Anna Young and Kevin Grubb for improvements to this paper. 


\section{LIST OF REFERENCES}

ADB, 2008. Key Indicators for Asia and the Pacific 2008. Asian Development Bank, Manila.

Agresti, A., Finlay, B., 1999. Statistical Methods for the Social Sciences $3^{\text {rd }}$ Edition. Prentice Hall, Inc., NJ.

Altieri, M.A., 1995. Agroecology: The Science of Sustainable Agriculture. Westview Press, Inc., Boulder.

Altieri, M.A., 2002. Agroecology; the science of natural resource management for poor farmers in marginal environments. Agric. Ecosyst. Environ. 93, 1-24.

Altieri, M.A., 2004. Linking ecologists and traditional farmers in the search for sustainable agriculture. Front. Ecol. Environ., 2, 35-42.

Anderson, J., Feder, G. R., 2004. Agricultural extension: good intentions and hard realities. World Bank Res. Obser. 19, 41-60.

CIA, 2009. Kyrgyzstan: Exchange Rates. CIA World Fact Book.

$<$ https://www.cia.gov/library/publications/the-world-factbook/print/kg.html $>$.

Currey, R.C.D., 2007. Apples in Home Gardens: Southern Shore, Lake Issyk-Kul, Kyrgyz Republic. Publication number MCK001/07. Mercy Corps Kyrgyzstan, Bishkek.

Dhur, A., 2009. Update on the food security and nutrition situation in the Kyrgyzstan Republic: Re-analysis of the Kyrgyz Integrated Household Survey $-1^{\text {st }}, 2^{\text {nd }}$, and $3^{\text {rd }}$ quarters of 2008 - National Statistics Committee. Regional Bureau for the Middle East, Central Asia and Eastern Europe (OMC), World Food Programme.

Dzhangaliev, A.D., Salova, T.N., Turekhanova, P.M., 2003. The wild fruit and nut plants of Kazakhstan. In: Janick, J. (Ed.), 2003, Wild Apple and Fruit Trees of Central Asia, Horticultural Review Volume 29, John Wiley \& Sons, NJ.

Fernandes, E.C.D., Nair, P.K.R., 1986. An evaluation of the structure and function of tropical homegardens. Agroforest. Syst., 21, 279-310.

Hazell, P.B.R., Ramasany, C., 1991. The Green Revolution reconsidered: the impact of high yielding rice varieties in South India. IFPRI, John Hopkins University, Washington, D.C.

Kompanion, 2008. Annual Report: 2007. Kompanion Financial Group, Bishkek. Kyrgyzstan. 
Kompanion, 2008b. Community cooperation nets $\$ 1.3$ million in apricot sales. Press Release: September 25, 2008. Kompanion Financial Group, Bishkek.

Kyrgyzstan Delegation, 2007. Statement by Kyrgyzstan. Part 1 of the Fifteenth Meeting of the OSCE Economic and Environmental Forum: Key challenges to ensure environmental security and sustainable development in the OSCE area: land degradation, soil contamination and water management. Organization for Security and Co-operationEurope. <http://www.osce.org/documents/eea/2007/01/23063_en.pdf>.

GKR, 2006. Kyrgyz Republic: Country Development Strategy 2007-2010. Government of the Kyrgyz Republic, Bishkek.

Kojekov, E., 2008. Report on Issyk-Kul Biosphere Reserve. Int. J. Environ. Sust. Dev. 7, 191-215.

Lerman, Z., 2006. The impact of land reform on rural household incomes in Transcaucasia. Eurasian Geogr. Econ., 47, 112-123.

Lerman, Z., 2008. Agricultural development in Central Asia: a survey of Uzbekistan, 2007-2008. Eurasian Geogr. Econ., 49, 481-505.

Lerman, Z., Stanchin, I., 2004. Institutional changes in Turkmenistan's agriculture: impracts on productivity and rural incomes. Eurasian Geogr. Econ., 45, 60-72.

Lerman, Z., Sutton, W.R., 2008. Productivity and efficiency of small and large farms in transition: evidence from Moldova. Post-Sov. Aff. 24, 97-120.

Lerman, Z., Tankhilevich, Ye., Mozhin, K., Sapova, N., 1994. Self-sustainability of subsidiary household plots: lessons for privatization of agriculture in Former Soviet Socialist Countries. Post-Sov. Geogr., 35, 526-542.

Lobell, D.A., Burke, M.B., Tebaldi, C., Mastrandrea, M.D., Falcon, W.P., Naylor, R.L., 2008. Prioritizing climate change adaptation needs for food security in 2030. Science., $319,607-610$.

Mazvimavi, K., Twomlow, S., 2009. Socioeconomic and institutional factors influencing adoption of conservation farming by vulnerable households in Zimbabwe. Agr. Syst, doi: 10.1016/j.agsy.2009.02.002.

McCune, B., Grace, J.B., 2002. Analysis of Ecological Communities. MjM Software Design, Oregon.

Méndez, V.E., Lok, R., Somarriba, E., 2001. Interdisciplinary analysis of homegardens in Nicaragua: micro-zonation, plant use and socioeconomic importance. Agroforest. Syst., 51, 85-96. 
Messerli, S., Abdykaparov, M., Taylor, P., 2006. Vocational education and training for woman farmers in Kyrgyzstan: A case study of an innovative education program. J. Vocat. Educ. Training 58, 455-469.

Naylor, R., Falcon, W., 2008. Our daily bread. Boston. Rev., 33, 13-18.

Nazarea, V.D., 1999. Ethnoecology. University of Arizona Press, Arizona.

Norris, K., 2008. Agriculture and biodiversity conservation: opportunity knocks. Conserv. Lett., 1, 2-11.

NSC, 2005. Sel'skoe khozyaistvo Kyrgyzskoy Respubliki 2003-2005 (Agriculture in the Kyrgyz Republic 2003-2005), in Russian. National Statistical Committee of the Kyrgyz Republic, Bishkek.

NSC, 2008. Sel'skoe khozyaistvo Kyrgyzskoy Respubliki 2005-2007 (Agriculture in the Kyrgyz Republic 2005-2007), in Russian. National Statistical Committee of the Kyrgyz Republic, Bishkek.

NSC, 2008b. Uroven bednosti vi Kyrgyzskoy Respubliki vi 2007 g. (Level of poverty in the Kyrgyz Republic in 2007), in Russian. National Statisitcs Committee of the Kyrgyz Republic, Bishkek <http://www.stat.kg/stat.files/tematikaбедность/Уровень бедности в 2007 г.pdf $>$

Pallot, J., Nefedova, T., 2004. Geographical differentiation in household plot production in rural Russia. Eurasian Geogr. Econ., 44, 40-64.

Picciotto, R., Anderson, J.R., 1997. Reconsidering agricultural extension. World Bank Res. Obser. 12, 249-259.

Pomfret, R.W.T., 1995. The Economies of Central Asia. Princeton University Press, Princeton.

Pretty, J.N, Morison, J.I.L., Hine, R.E., 2003. Reducing food poverty by increasing agricultural sustainability in developing countries. Agric. Ecosyst. Environ. 95, 217-234.

Schmidt, M., Sagynbekova, L., 2008. Migration past and present: changing patterns in Kyrgyzstan. Cent. Asian Surv. 27, 111-127.

Seeth, H.T., Chachnov, S., Surinov, A., Von Braun, J., 1998. Russian poverty: muddling through economic transition with garden plots. World Dev., 26, 1611-1623.

Senthilkumar, K., Bindraban, P.S., Thiyagarajan, T.M., de Ridder, N., Giller, K.E., 2008. Modified rice cultivation in Tamil Nadu, India: yield gains and farmers' (lack of) acceptance. Agr. Syst., 98, 82-94. 
Sharashkin, L., 2008. The socioeconomic and cultural significance of food gardening in the Vladimir region of Russia. Ph.D. Dissertation, University of Missouri, Columbia.

Sharma, R., 2002. Reforms in agricultural extension: new policy framework. Econ. Polit. Wkly, 3124-3131.

Shkurov, E., Makeev, T., Koshoev, M. (Eds.), 2007. Kyrgyzstan: Environment and Natural Resources for Sustainable Development, 2007. State Agency on Environment Protection and Forestry under the Government of the Kyrgyz Republic and the United Nations Development Programme in the Kyrgyz Republic. Bishkek.

SPSS, 2007. SPSS 16.0 for Mac. Release 16.0.1. SPSS Inc., Chicago.

Swinton, S.M., Quiroz, R., 2003. Is poverty to blame for soil, pasture, and forest degradation in Peru's Altiplano? World Dev., 31, 1903-1919.

SYSTAT, 2007. SYSTAT for Windows. Version No. 12.02.00. SYSTAT Software, Inc.

Ter-Ghazaryan, D., Heinen, J.T., Reserve management during transition: the case of Issyk-kul Biosphere and Nature Reserves, Kyrgyzstan. Environ. Pract. 8, 11-23.

Tilman, D., 1999. Global environmental impacts of agricultural expansion: the need for sustainable and efficient practices. Proc. Nat. Acad. Sci. U., A 96, 5995-6000.

Tripp, R., 2006. Low external-input technology (LEIT) and agricultural development. In: Tripp, R. (Ed.), 2006, Self-Sufficient Agriculture: Labour and Knowledge in Small-Scale Farming. Earthscan, London.

Van Atta, D., 1998. Household budgets in Ukraine: a research report. Post-Sov. Geogr. Econ., 39, 606-616.

Wegren, S.K., 2004. Russian peasant farms and household plots in 2003: a research note. Eurasian Geogr. Econ. 45, 230-239.

World Bank, 2005. Farm Structure and Agricultural Productivity. Kyrgyzstan Agricultural Sector: Policy Note 2. World Bank Country Office in the Kyrgyz Republic, Bishkek.

Zingore, S., González-Estrada, E., Delve, R.J., Herrero, M., Dimes, J.P., Giller, K.E., 2009. An integrated evaluation of strategies for enhancing productivity and profitability of resource-constrained smallholder farms in Zimbabwe. Agr. Syst., doi:

10.1016/j.agsy.2009.03.003. 
Table 1. Characteristics of households in December 2008, both participants in agricultural development initiative $(\mathrm{N}=267)$ and non-participants $(\mathrm{N}=335)$, from eight villages, Issyk-kul region, northeastern Kyrgyzstan.

\begin{tabular}{lrrr}
\hline & Mean & Std. Dev. & Range \\
\hline Household size & 4.9 & 1.80 & $1-12$ \\
$\quad$ Minors & 2.0 & 1.41 & $0-7$ \\
Income earners & 2.1 & 0.94 & $0-6$ \\
Respondent & & & \\
$\quad$ Age (years) & 46.5 & 13.65 & $14-96$ \\
Gender (1=female) & 0.49 & 0.50 & - \\
Family Status (1=married) & 0.83 & 0.38 & - \\
\hline
\end{tabular}


Table 2. Characteristics of household income pre- (2007) and post- (2008) development initiative agricultural trainings for participants $(\mathrm{N}=267)$, from eight villages, northeastern Kyrgyzstan. \$1 USD = 37.75 KGS in 2007; \$1 USD = 36.11 KGS in 2008.

\begin{tabular}{|c|c|c|c|c|c|c|}
\hline \multirow[t]{2}{*}{ Participants (PR) } & \multicolumn{3}{|c|}{2007 Pre-Agricultural Trainings } & \multicolumn{3}{|c|}{2008 Post-Agricultural Trainings } \\
\hline & Mean & Std. Dev. & Range & Mean & Std. Dev. & Range \\
\hline Total Income (KGS) & $62,294.2$ & $61,346.62$ & $0-372,000$ & $72,954.7$ & 68182.82 & $\begin{array}{r}5,000- \\
469,000\end{array}$ \\
\hline Total Agriculture & $15,245.9$ & $22,266.69$ & $0-218,000$ & $18,733.9$ & $31,242.18$ & $0-340,000$ \\
\hline Home gardens & $10,568.6$ & $17,564.76$ & $0-200,000$ & $13,087.5$ & $19,822.81$ & $0-180,000$ \\
\hline Apple sales & $5,133.0$ & $7,654.38$ & $0-72,000$ & $6,386.7$ & $9,486.05$ & $0-50,000$ \\
\hline Other agriculture & $4,677.4$ & $11,143.82$ & $0-126,000$ & $5,646.4$ & $14,633.09$ & $0-160,000$ \\
\hline $\begin{array}{l}\text { Total Livestock } \\
\text { Livestock/Animal }\end{array}$ & $12,289.6$ & $22,258.94$ & $0-212,600$ & $13,705.8$ & $17,757.23$ & $0-100,000$ \\
\hline Products & $10,475.1$ & $20,391.39$ & $0-200,000$ & $11,876.7$ & $17,005.90$ & $0-100,000$ \\
\hline Milk/Wool/Eggs & $1,791.6$ & $6,017.80$ & $0-63,000$ & $1,565.0$ & $3,778.93$ & $0-24,000$ \\
\hline Rabbits/Chickens & 22.9 & 206.75 & $0-3,000$ & 264.0 & $2,228.65$ & $0-30,000$ \\
\hline Total Formal & $23,303.7$ & $44,242.87$ & $0-264,000$ & $25,916.0$ & $54,121.27$ & $0-450,000$ \\
\hline Employment & & & & & & \\
\hline Salary & $20,441.2$ & $42,195.04$ & $0-264,000$ & $21,457.4$ & $53,869.18$ & $0-450,000$ \\
\hline Wages & $2,862.4$ & $14,721.57$ & $0-210,000$ & $4,458.6$ & $13,703.43$ & $0-100,000$ \\
\hline Business & $3,679.0$ & $12,546.69$ & $0-125,000$ & $3,535.6$ & $12,329.42$ & $0-75,000$ \\
\hline Pension/Social Benefits & $6,554.7$ & $9,151.70$ & $0-48,000$ & 8673.9 & $11,049.45$ & $0-66,000$ \\
\hline Relatives/Gifts & $1,146.4$ & $2,756.64$ & $0-30,000$ & $1,752.8$ & $4,565.80$ & $0-40,000$ \\
\hline
\end{tabular}


Table 3. Characteristics of household income pre- (2007) and post- (2008) development initiative agricultural trainings for non-participants $(\mathrm{N}=335)$, from eight villages, northeastern Kyrgyzstan. \$1 USD = 37.75 KGS in 2007; \$1 USD = 36.11 KGS in 2008.

\begin{tabular}{|c|c|c|c|c|c|c|}
\hline \multirow{2}{*}{$\begin{array}{l}\text { Non-participants } \\
\text { (NPR) }\end{array}$} & \multicolumn{3}{|c|}{2007 Pre-Agricultural Trainings } & \multicolumn{3}{|c|}{2008 Post-Agricultural Trainings } \\
\hline & Mean & Std. Dev. & Range & Mean & Std. Dev. & Range \\
\hline Total Income (KGS) & $65,464.7$ & $67,118.76$ & $0-547,000$ & $63,921.9$ & $61,755.02$ & $\begin{array}{l}1,000- \\
716,568\end{array}$ \\
\hline Total Agriculture & $12,007.9$ & $15,608.15$ & $0-95,000$ & $14,719.4$ & $20,087.05$ & $0-150,000$ \\
\hline Home gardens & $8,315.6$ & $11,657.19$ & $0-90,000$ & $10,689.1$ & $15,803.37$ & $0-150,000$ \\
\hline Apple sales & $3,522.2$ & $6,328.77$ & $0-60,000$ & $6,284.3$ & $12,413.94$ & $0-150,000$ \\
\hline Other agriculture & $3,691.4$ & $9,183.89$ & $0-83,000$ & $4,030.3$ & $8,699.82$ & $0-100,000$ \\
\hline Total Livestock & $10,773.1$ & $19,255.15$ & $0-154,500$ & $10,423.7$ & $13,505.29$ & $0-70,000$ \\
\hline $\begin{array}{l}\text { Livestock/Animal } \\
\text { Products }\end{array}$ & $9,773.6$ & $18,807.51$ & $0-150,000$ & 9024.7 & $12,769.48$ & $0-70,000$ \\
\hline Milk/Wool/Eggs & 986.1 & $2,862.22$ & $0-24,000$ & $1,356.7$ & $3,332.17$ & $0-24,000$ \\
\hline Rabbits/Chickens & 13.43 & 146.72 & $0-2,000$ & 42.4 & 246.76 & $0-3,000$ \\
\hline $\begin{array}{l}\text { Total Formal } \\
\text { Employment }\end{array}$ & $28,475.7$ & $58,314.32$ & $0-522,000$ & $21,803.9$ & $41,697.11$ & $0-360,000$ \\
\hline Salary & $25,032.6$ & $57,780.12$ & $0-522,000$ & $18,536.6$ & $18,536.63$ & $0-360,000$ \\
\hline Wages & $3,443.2$ & $10,556.55$ & $0-100,000$ & $3,267.3$ & $9,231.14$ & $0-65,000$ \\
\hline Business & $4,569.6$ & $15,325.82$ & $0-200,000$ & $4,761.2$ & $30,077.58$ & $0-500,000$ \\
\hline $\begin{array}{l}\text { Pension/Social } \\
\text { Benefits }\end{array}$ & $7,985.0$ & $16,518.92$ & $0-204,100$ & 9068.8 & $11,724.65$ & $0-64,800$ \\
\hline Relatives/Gifts & $1,116.1$ & $2,221.91$ & $0-10,000$ & 3144.8 & $13,079.81$ & $0-200,000$ \\
\hline
\end{tabular}


Table 4. Comparison of the proportions of households in the two groups, participants $(\mathrm{N}=267)$ and non-participants $(\mathrm{N}=335)$, using different management practices in 2007 (PR and NPR) and 2008 (PR and NPR). Two-sample tests for differences in means between groups (t-test and z-tests for proportions); degrees of freedom $=600$ for all.

\begin{tabular}{|c|c|c|c|c|c|c|c|c|c|c|}
\hline & \multicolumn{5}{|c|}{2007} & \multicolumn{5}{|c|}{2008} \\
\hline & Total & PR & NPR & $\begin{array}{l}\text { z/t- } \\
\text { value }\end{array}$ & $\mathrm{p}$ & Total & PR & NPR & $\begin{array}{l}\text { z/t- } \\
\text { value }\end{array}$ & $\mathrm{p}$ \\
\hline Total Practices & 3.47 & 3.65 & 3.33 & 2.59 & 0.010 & 4.14 & 4.51 & 3.85 & 4.65 & $<0.000$ \\
\hline (Std. Dev.) & 1.51 & 1.51 & 1.50 & & & 1.783 & 1.65 & 1.83 & & \\
\hline \multirow[t]{2}{*}{ Pruning } & 0.82 & 0.85 & 0.80 & 1.48 & 0.141 & 0.88 & 0.91 & 0.85 & 1.96 & 0.051 \\
\hline & 0.384 & 0.361 & 0.401 & & & 0.329 & 0.292 & 0.354 & & \\
\hline \multirow[t]{2}{*}{ Grafting } & 0.65 & 0.67 & 0.63 & 0.96 & 0.338 & 0.67 & 0.72 & 0.63 & 2.37 & 0.019 \\
\hline & 0.478 & 0.471 & 0.483 & & & 0.470 & 0.448 & 0.483 & & \\
\hline \multirow[t]{2}{*}{ Thinning } & 0.33 & 0.37 & 0.29 & 2.12 & 0.035 & 0.51 & 0.57 & 0.46 & 2.76 & 0.006 \\
\hline & 0.469 & 0.484 & 0.454 & & & 0.500 & 0.496 & 0.499 & & \\
\hline \multicolumn{11}{|l|}{ Organic } \\
\hline \multirow[t]{2}{*}{ Fertilizer } & 0.81 & 0.82 & 0.81 & 0.56 & 0.574 & 0.86 & 0.88 & 0.83 & 1.77 & 0.077 \\
\hline & 0.389 & 0.382 & 0.396 & & & 0.352 & 0.321 & 0.374 & & \\
\hline \multirow[t]{2}{*}{ Bio-pest Control } & 0.16 & 0.21 & 0.13 & 2.57 & 0.010 & 0.32 & 0.36 & 0.28 & 1.89 & 0.058 \\
\hline & 0.369 & 0.405 & 0.335 & & & 0.465 & 0.480 & 0.451 & & \\
\hline \multirow[t]{2}{*}{ Composting } & 0.29 & 0.32 & 0.27 & 1.25 & 0.211 & 0.56 & 0.67 & 0.47 & 4.90 & $<0.000$ \\
\hline & 0.455 & 0.467 & 0.445 & & & 0.497 & 0.471 & 0.500 & & \\
\hline \multirow[t]{2}{*}{ Buy Saplings } & 0.41 & 0.42 & 0.40 & 0.39 & 0.697 & 0.35 & 0.40 & 0.31 & 2.40 & 0.016 \\
\hline & 0.492 & 0.494 & 0.491 & & & 0.478 & 0.492 & 0.463 & & \\
\hline
\end{tabular}


Table 5. Adoption of home garden management practices by participants $(\mathrm{N}=267)$ and non-participants $(\mathrm{N}=335)$ following development initiative using McNemar's test for symmetry for comparing dependent proportions. Percentage of households that adopted practices and those that continued practices from 2007 to 2008 reported.

\begin{tabular}{|c|c|c|c|c|c|c|c|c|}
\hline & \multicolumn{4}{|c|}{ Participants } & \multicolumn{4}{|c|}{ Non-Participants } \\
\hline & $\begin{array}{c}\text { Adopted } \\
(\%)\end{array}$ & $\begin{array}{c}\text { Continued } \\
(\%)\end{array}$ & $\chi_{\mathrm{df}=1}^{2}$ & $\mathrm{p}$ & $\begin{array}{c}\text { Adopted } \\
(\%)\end{array}$ & $\begin{array}{c}\text { Continued } \\
(\%)\end{array}$ & $\chi_{\mathrm{df}=1}^{2}$ & $\mathrm{p}$ \\
\hline Pruning & 12.4 & 78.3 & 5.12 & 0.024 & 13.7 & 71.6 & 4.38 & 0.036 \\
\hline Grafting & 20.3 & 52.1 & 2.09 & 0.149 & 17.3 & 45.9 & $<0.01$ & 1.000 \\
\hline Thinning & 28.8 & 28.1 & 27.81 & $<0.000$ & 26.4 & 19.5 & 26.13 & $<0.000$ \\
\hline $\begin{array}{l}\text { Organic } \\
\text { Fertilizer }\end{array}$ & 14.6 & 73.8 & 4.13 & 0.042 & 13.4 & 69.9 & 1.00 & 0.317 \\
\hline $\begin{array}{l}\text { Bio-pest } \\
\text { Control }\end{array}$ & 24.7 & 10.9 & 17.39 & $<0.000$ & 21.8 & 6.6 & 28.77 & $<0.000$ \\
\hline Composting & 41.6 & 25.5 & 69.03 & $<0.000$ & 29.6 & 17.9 & 35.57 & $<0.000$ \\
\hline $\begin{array}{l}\text { Buy } \\
\text { Saplings }\end{array}$ & 21.7 & 18.7 & 0.08 & 0.783 & 17.6 & 13.4 & 6.08 & 0.014 \\
\hline
\end{tabular}

Table 6. Simple linear regression models predicting square-root transformed home garden and apple sales income for participant and non-participant households, combined, following home garden development initiative targeting low external-input technology techniques by horticultural/agricultural management practice.

\begin{tabular}{|c|c|c|c|c|c|c|c|c|}
\hline & \multicolumn{4}{|c|}{ Home Garden Income } & \multicolumn{4}{|c|}{ Apple Sales Income } \\
\hline & $\begin{array}{c}\mathrm{t}- \\
\text { statistic }\end{array}$ & $\begin{array}{c}\mathrm{F} \\
\mathrm{df}=1,591\end{array}$ & $\begin{array}{l}\mathrm{p}- \\
\text { value }\end{array}$ & $\mathrm{r}^{2}$ & $\begin{array}{l}\mathrm{t}- \\
\text { statistic }\end{array}$ & $\begin{array}{c}\mathrm{F} \\
\mathrm{df}=1,582\end{array}$ & $\begin{array}{l}\mathrm{p}- \\
\text { value }\end{array}$ & $\mathrm{r}^{2}$ \\
\hline Number of practices & 2.57 & 6.60 & 0.010 & 0.011 & 3.20 & 10.22 & 0.001 & 0.017 \\
\hline $\begin{array}{l}\text { Participant in horticultural } \\
\text { development initiative }\end{array}$ & 1.57 & 2.46 & 0.118 & 0.004 & 1.80 & 3.25 & 0.072 & 0.006 \\
\hline Management Practices & & & & & & & & \\
\hline Pruning & 4.91 & 24.08 & $<0.000$ & 0.039 & 5.56 & 30.91 & $<0.000$ & 0.050 \\
\hline Grafting & 1.00 & 9.93 & 0.002 & 0.017 & 2.19 & 4.78 & 0.029 & 0.008 \\
\hline Thinning & -5.53 & 30.61 & $<0.000$ & 0.049 & -1.65 & 2.72 & 0.099 & 0.005 \\
\hline Organic Fertilizer & 5.20 & 27.06 & $<0.000$ & 0.044 & 2.88 & 8.33 & 0.004 & 0.014 \\
\hline Bio-pest Control & 2.42 & 5.85 & 0.016 & 0.010 & 2.26 & 5.10 & 0.024 & 0.009 \\
\hline Composting & 1.17 & 2.76 & 0.097 & 0.005 & 2.11 & 4.47 & 0.035 & 0.008 \\
\hline
\end{tabular}




\section{CHAPTER VII}

\section{SUMMARY}

Smallholder farming systems, home gardens, are critical for the food security of households throughout the developing world. Human dominated landscapes are becoming more important for the conservation of biodiversity with agricultural expansion being a major driver of intact habitat conversion. Mitigating negative environmental effects associated with agricultural growth such as agrobiodiversity and biodiversity loss and the loss of ecosystem services, such as pollination is our challenge. Home gardens and other agroforestry systems can serve as reservoirs for biodiversity, not only for food crops, but also other organisms such as molluscs, insects and birds. However, as concerns about food security increase, the effects of climate change manifest themselves and calls for agricultural intensification come to fruition, conserving existing agroecosystems, home gardens, and the diversity of plants and other organisms within them face serious challenges. Agricultural ecosystems are human systems. Management decisions that impact biodiversity and the ecosystem effects of those decisions are based as much on economic necessity and cultural traditions as they are on ecological factors. These factors must all be simultaneously considered to address the conservation issues associated with agricultural intensification and to improve long-term growth in agricultural productivity in smallholder farming systems for hunger and poverty reduction. 
My aim was to evaluate the importance of home garden agroecosystems in Kyrgyzstan for the conservation of agrobiodiversity and Hymenoptera using an ethnoecological approach to research and then to apply these findings to inform and improve management practices that have the potential to improve agricultural productivity while maintaining biodiversity. I reviewed the current status of research pertaining to home gardens and agrobiodiversity and how an ethnoecological approach to home garden research could improve out understanding of factors influencing biodiversity in human agricultural systems. I then applied this approach to study the agrobiodiversity and the Hymenoptera of home gardens. I assessed the edible plant species and Hymenoptera insect species in home gardens and evaluated the factors that contributed to the diversity of these organisms in home gardens, and, for Hymenoptera, in orchards, also. I also designed and evaluated an applied ethnoecological development initiate that sought to provide an economic incentive through improved incomes from the sales of agricultural production for the improvement of management practices that maintain or enhance biodiversity and ecosystem services in home gardens. This research took place in Issyk-kul (Kyrgyz Republic), primarily in the villages of Tosor and Tamga, Djeti-Oguz (Issyk-kul Man and Biosphere reserve).

The results show that temperate home gardens in Kyrgyzstan are diverse with an average of 24 edible plant species per home garden, more diverse even than some tropical home gardens, and that plant material received from others (relatives and neighbors) was an important factor in determining diversity status of cultivated plants. Different methods used to document cultivated species diversity yield different results; mapping home 
gardens with members of the household revealed $40 \%$ more species than in an interview context. The relationship of explanatory variables to mapped fruit species diversity in Kyrgyz home gardens, especially the variables of home garden size, additional plots owned, and age of home garden, differed from similar studies in primarily tropical home garden agroecosystems.

Home gardens also support diverse and abundant Hymenoptera, many of which are pollinators of the cultivated crops grown in home gardens. I collected 765 Hymenoptera individuals belonging to 56 bee and 13 wasp species with 12 of these species being new species occurrences in Kyrgyzstan (six) or within Kyrgyzstan (six). Average height of vegetation was the best predictor of Hymenoptera richness and abundance, bee abundance and richness, as well as solitary bee abundance and richness. Vegetative ground cover best predicted wasp abundance and diversity and bumblebee richness and abundance. I found that there were no significant differences in Hymenopteran community composition between home gardens and orchards.

I provided empirical evidence that organic, high elevation home gardens and orchards of the arid Issyk-Kul region, as currently managed, support abundant and diverse pollinator communities and high levels of agrobiodiversity. Economic pressures to intensify cultivation in home gardens could impact management practices that currently promote the insect and cultivated plant diversity in Kyrgyz home gardens I documented. I investigated the effectiveness of low-external input technology (LEIT) agricultural extension for home garden management practice improvement that integrated improved 
agricultural techniques into current practice to increase the sustainability of agriculture for home gardeners. Households were interviewed before and after the agricultural extension program. I demonstrated that there were significant rates of adoption for nearly all techniques, indicating diffusion of knowledge from the participants in agricultural extension and non-participants, the controls. However, direct participants had higher rates of adoption of management practices that impact long-term yield, and thus income, sustainability and stability such as composting, thinning of fruits, grafting and seedling establishment. I found a direct link between the adoption of management techniques and increased income. Targeting home gardens for agricultural development initiatives based on prior ethnoecological research and agroecological principles that also include mobilization, marketing, and improved access to credit improves management practices that can promote diversity and improve household income. Home gardens can and do play an important role in food and income provision while supporting diverse plant and insect communities. 
Appendix 1: Selected crop wild relatives that occur in the Kyrgyz Republic, Central Asia, in the order they are mentioned in the text (MEP 1998, Dzhangaliev et al. 2003, Eastwood et al. 2009).

\begin{tabular}{lll}
\hline $\begin{array}{l}\text { English common } \\
\text { name }\end{array}$ & Family & Scientific name \\
\hline Apple & Rosaceae & \\
Apricot & & Malus sieversii (Lebed.) M.Roem \\
Pear & Armeniaca vulgaris Lam. \\
& & Pyrus communis L. \\
& & P. korshinskyi Litv. \\
Cherry & P. regelii Rehd. \\
& & Cerasus avium (L.) Moench \\
Plum & & Cerasus vulgaris Mill. \\
& & Prunus cerasifera Ehrh. \\
Raspberry & & P. sogdiana Vassilcz. \\
Currant \& Gooseberry & Grossulariaceae & Rubus spp. L. \\
Grape & Ribes spp. L. \\
Almond & Vitaceae & Aitis vinifera L. \\
& Rosaceae & A. bucharica Korsh. \\
Pistachio & & A. petunnikovii Litv. \\
Walnut & Pistacia vera L. \\
& & Juglans regia L. \\
& &
\end{tabular}


Appendix 2: List of Edible Fruits and Vegetables Cultivated in Home Gardens, Tosor and Tamga, Kyrgyz Republic.

\begin{tabular}{|c|c|c|c|c|c|}
\hline Russian & Kyrgyz & $\begin{array}{l}\text { English } \\
\text { name }\end{array}$ & $\begin{array}{l}\text { Scientific name } \\
\text { [Family noted when } \\
\text { species unknown] }\end{array}$ & $\begin{array}{l}\text { \% Home } \\
\text { Garden } \\
\text { (Map) }\end{array}$ & $\begin{array}{l}\text { \% Home } \\
\text { Garden } \\
\text { (Report) }\end{array}$ \\
\hline FRUIT & & & & $(\mathrm{N}=20)$ & $(\mathrm{N}=21)$ \\
\hline Yabloko & Alma & Apple & Malus pumila Mill. & 100 & 100 \\
\hline Abrikos & Uruk & Apricot & Armeniaca vulgaris Lam. & 100 & 100 \\
\hline Grusha & Almurut & Pear & Pyrus communis L. & 90 & 86 \\
\hline Funduk & - & Hazelnut & Corylus L. [Betulaceae] & 5 & - \\
\hline Chereshniya & Alcha & $\begin{array}{l}\text { Sweet } \\
\text { cherry }\end{array}$ & $\begin{array}{l}\text { Cerasus avium (L.) } \\
\text { Moench }\end{array}$ & 75 & 52 \\
\hline Vishniya & Chiye & Sour cherry & Cerasus vulgaris Mill. & 50 & 52 \\
\hline Sakura & - & $\begin{array}{l}\text { Oshima- } \\
\text { zakura } \\
\text { cherry }\end{array}$ & $\begin{array}{l}\text { Cerasus serrulata (Lindl.) } \\
\text { Loudon }\end{array}$ & 5 & - \\
\hline $\begin{array}{l}\text { Gretskiy } \\
\text { Orekh }\end{array}$ & Jangak & Walnut & Juglans regia $\mathrm{L}$. & 55 & 43 \\
\hline Sleeva & Kara-uruk & Plum & Prunus domestica L. & 45 & 29 \\
\hline Tyorn & $\begin{array}{l}\text { Japai kara- } \\
\text { uruk }\end{array}$ & Wild plum & Prunus L. [Rosaceae] & 15 & - \\
\hline Persik & Shabdaliy & Peach & $\begin{array}{l}\text { Prunus persica }(\mathrm{L} .) \\
\text { Batsch }\end{array}$ & 35 & 29 \\
\hline $\begin{array}{l}\text { Chyornaya } \\
\text { Smorodina }\end{array}$ & $\begin{array}{l}\text { Kapa- } \\
\text { Karagat }\end{array}$ & $\begin{array}{l}\text { Currant } \\
\text { (Black) }\end{array}$ & Ribes nigrum $\mathrm{L}$. & 95 & 76 \\
\hline $\begin{array}{l}\text { Krasnaya } \\
\text { Smorodina }\end{array}$ & $\begin{array}{l}\text { Kyzyl- } \\
\text { Karagat }\end{array}$ & $\begin{array}{l}\text { Currant } \\
\text { (Red) }\end{array}$ & Ribes rubrum L. & 35 & 5 \\
\hline $\begin{array}{l}\text { Belaya } \\
\text { Smorodina }\end{array}$ & Ak-Karagat & $\begin{array}{l}\text { Currant } \\
\text { (Golden) }\end{array}$ & Ribes aureum Pursh & 5 & - \\
\hline Krizhovnik & Barsildak & Gooseberry & Ribes uva-crispa L. & 15 & 10 \\
\hline Yoshta & - & Joshtaberry & $\begin{array}{l}\text { Ribes } x \text { nidigrolaria Rub. } \\
\text { Bauer \& A. Bauer }\end{array}$ & 5 & - \\
\hline Maleena & Maleena & Raspberry & Rubus L. [Rosaceae] & 50 & 43 \\
\hline Barbaris & $\begin{array}{l}\text { Boru- } \\
\text { kapagat }\end{array}$ & Barberry & $\begin{array}{l}\text { Berberis L. } \\
\text { [Berberidaceae] }\end{array}$ & 5 & - \\
\hline Vinograd & Juzum & Grape & Vitis vinefera.L. & 10 & 5 \\
\hline Klubnika & Buldurkon & Strawberry & Fragaria [Rosaceae] & 25 & 5 \\
\hline Kalina & - & Viburnum & Viburnum L. [Adoxaceae] & 5 & 5 \\
\hline VEGETABLE & & & & $(\mathrm{N}=10)$ & $(\mathrm{N}=20)$ \\
\hline Chesnok & Sarimsak & Garlic & Allium sativum L. & 60 & 80 \\
\hline Luk & Piyaz & Onion & Allium cepa $\mathrm{L}$. & 60 & 50 \\
\hline Jusai & Jusai & Jusai & Allium L. [Alliaceae] & 50 & - \\
\hline
\end{tabular}




\begin{tabular}{|c|c|c|c|c|c|}
\hline Kapusta & Kapusta & $\begin{array}{l}\text { Cabbage, } \\
\text { Broccoli, } \\
\text { Kholrabi }\end{array}$ & Brassica oleracea L. & 90 & 65 \\
\hline Pomidor & Pomidor & Tomato & Solanum lycopersicum L. & 100 & 50 \\
\hline Rapis & - & Rape & Brassica napus $\mathrm{L}$. & 10 & \\
\hline Ogurets & Badirang & Cucumber & Cucumis sativus L. & 100 & 45 \\
\hline Fasol & Fasol & Bean & Phaseolus L. [Fabaceae] & 50 & 30 \\
\hline Bobi & $\begin{array}{l}\text { Too } \\
\text { buurchak }\end{array}$ & Faba bean & Vicia faba $\mathrm{L}$. & 20 & 10 \\
\hline Gorokh & Buurchak & Pea & Pisum sativum L. & 30 & 5 \\
\hline Tikva & Ashkabak & $\begin{array}{l}\text { Winter } \\
\text { squash }\end{array}$ & $\begin{array}{l}\text { Cucurbita moschata } \\
\text { Duchesne }\end{array}$ & 10 & 10 \\
\hline $\begin{array}{l}\text { Patison, } \\
\text { Kabachok }\end{array}$ & $\begin{array}{l}\text { Patison/ } \\
\text { Kabachok }\end{array}$ & $\begin{array}{l}\text { Squash/ } \\
\text { Zucchini }\end{array}$ & Cucurbita pepo L. & 30 & 5 \\
\hline Perets & Kalempir & Pepper & Capsicum annuum $\mathrm{L}$. & 10 & 5 \\
\hline Kukuruza & $\begin{array}{l}\text { Jugoru, } \\
\text { Konok }\end{array}$ & Corn & Zea mays $\mathrm{L}$. & 20 & - \\
\hline Ukrop & Ukrop & Dill & Anethum graveolens L. & 40 & 5 \\
\hline Petrushka & - & Parsley & $\begin{array}{l}\text { Petroselinum crispum } \\
\text { (Mill.) Fuss }\end{array}$ & 30 & - \\
\hline Kinza & - & Coriander & Coriandrum sativum L. & 20 & - \\
\hline Bazelik & - & Basil & Ocimum L. [Lamiaceae] & 10 & - \\
\hline Shavel & Kozukulak & Sorrel & Rumex acetosa $\mathrm{L}$. & 20 & - \\
\hline Kartofel & Kartofel & Potato & Solanum tuberosum L. & 80 & 75 \\
\hline Morkov & Sabiz & Carrot & Daucus carota $\mathrm{L}$. & 80 & 75 \\
\hline Svekla & Kyzylcha & $\begin{array}{l}\text { Beet (Red, } \\
\text { Sugar, } \\
\text { Fodder) }\end{array}$ & Beta vulgaris $\mathrm{L}$. & 80 & 25 \\
\hline $\begin{array}{l}\text { Rediska, } \\
\text { Redka }\end{array}$ & $\begin{array}{l}\text { Chamgir, } \\
\text { Turp }\end{array}$ & $\begin{array}{l}\text { Radish } \\
\text { (Red, Black) }\end{array}$ & Raphanus sativus L. & 30 & 10 \\
\hline Khren & - & Horseradish & $\begin{array}{l}\text { Armoracia rusticana P. } \\
\text { Gaertn., B. Mey. \& } \\
\text { Scherb. }\end{array}$ & 70 & - \\
\hline Pasternak & - & Wild parsnip & Pastinaca sativa L. & 10 & - \\
\hline Salat & - & Lettuce & Lactuca sativa $\mathrm{L}$. & 30 & - \\
\hline Podsolnukh & Smimichke & Sunflower & Helianthus annuus $\mathrm{L}$. & 20 & - \\
\hline Topuhnambur & - & $\begin{array}{l}\text { Jerusalem } \\
\text { artichoke }\end{array}$ & Helianthus tuberosus L. & 20 & - \\
\hline Sparsh & - & Asparagus & Asparagus officinalis L. & 10 & - \\
\hline Khmel & Achitki & Hops & Humulus lupulus L. & 50 & 5 \\
\hline
\end{tabular}


Appendix 3. Hymenoptera collected in home gardens (HG) and orchards (O) in 2005 and 2006, Tosor and Tamga, Issyk-kul Oblast, Kyrgyz Republic.

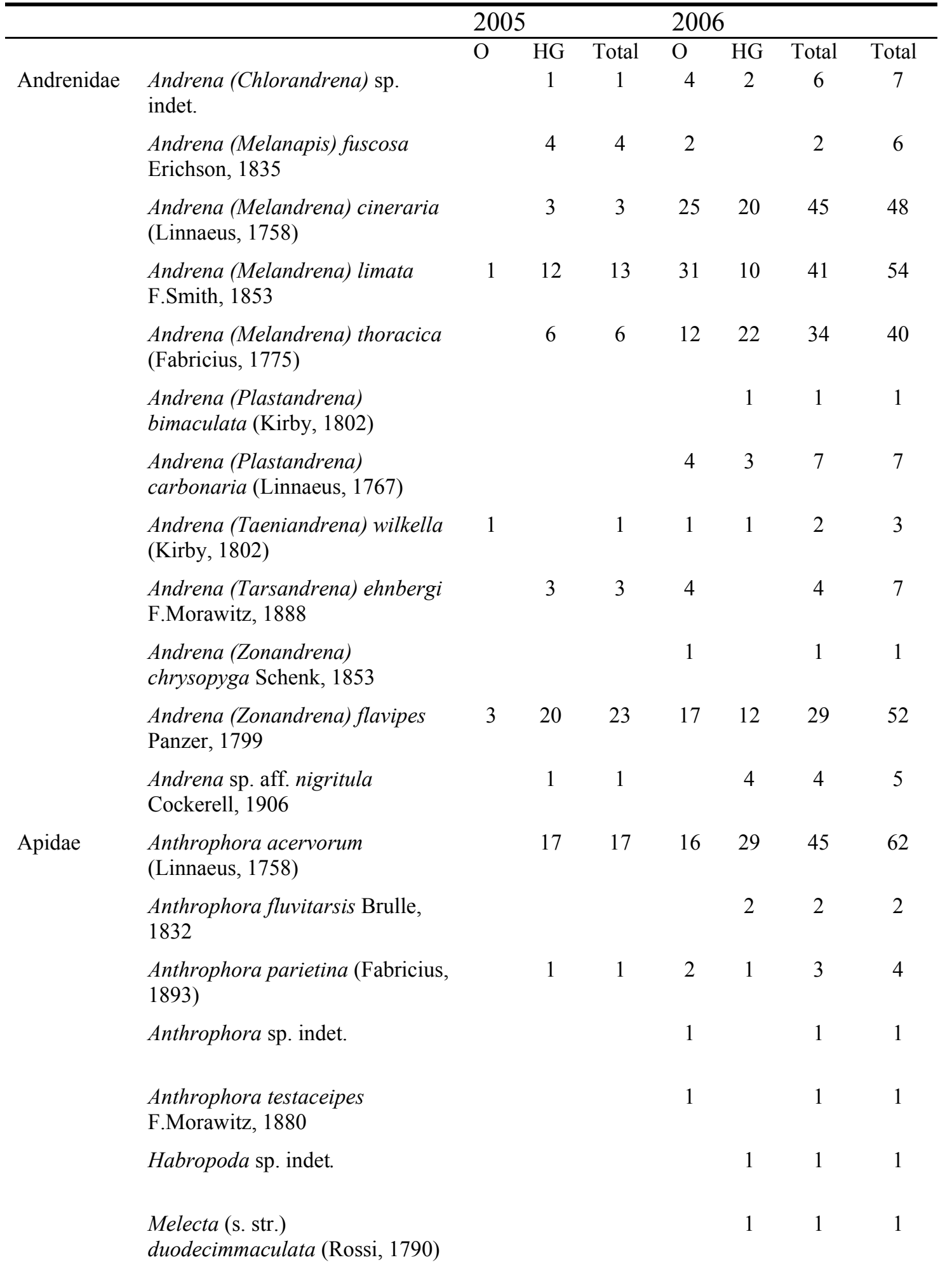


Nomada lathburiana (Kirby, 1802)

Nomada mutica F.Morawitz, 1872

Paramegilla radoszkowskyi

(Fedtschenko, 1875)

Proxylocopa (Ancylocopa) nitidiventris (F.Smith, 1878)

2

Proxylocopa (s. str.) olivieri (Lepeletier, 1841)

Proxylocopa (s. str.) rufa Friese, 1901

Xylocopa (s. str.) valga Gerstaecker, 1872

Apis (s. str.) mellifera (Linnaeus, 1758)

Bombus (?Agrobombus) maculidorsis (Skorikov, 1922)

Bombus (Megabombus) melanurus Lepeletier, 1836

Bombus (s. str.) lucorum (Linnaeus, 1761)

Bombus (s. str.) terrestris (Linnaeus, 1758)

Bombus (Subterraneobombus) fragrans (Pallus, 1771)

Bombus (Thoracobombus) muscorum (Linnaeus, 1758)

Halictidae

Halictus (Monilapis) compressus (Walckenaer, 1802) ssp. transvolgensis Pensko, 1985 Halictus (Tytthalictus) maculatus F.Smith, 1848

Halictus (Tytthalictus) sp. indet.

Lasioglossum (Dialctus) sp. aff. leucopus (Kirby, 1802)

Lasioglossum (Evylaeus) albipes (Fabricius, 1781) 
Seladonia (Mucoreohalictus)

pollinosa (Sichel, 1860) ssp.

cariniventris (F.Morawitz, 1876)

Halictus subaurataus (Rossi,

1792)

Sphecodes pellucidus F.Smith, 1848

Megachil-

idae
Chelostoma proximum

Schletterer, 1889

Coelioxys argentea Lepeletier, 1841

Coelioxys rufescens Lepeletier, 1825

Hoplitis (Megalosmia) fulva

(Eversmann, 1852)

Megachile (Chalicodoma)

parietina (Geoffroy, 1785) ssp.

nestorea (Brulle, 1832)

Megachile (s. str.) centuncularis

(Linnaeus, 1758)

Osmia (Chalcosmia)

caerulescens (Linnaeus, 1758)

Osmia (Chalcosmia) leaiana

(Kirby, 1802)

Osmia (s. str.) rufa (Linnaeus, 1758)

Stelis (s. str.) phaeoptera (Kirby, 1802)

Chrysididae

Chrysis chinensis Mocsáry, 1912

Ichneumon- Buathra evidens (Kokujev, 1909) idae

Pimpla turionellae (Linnaeus, 1758)

Sphecidae

Crossocerus (Blepharipus)

megacephalus (Rossi, 1790)

Ectemnius (Clytochrysus)

lapidarius (Panzer, 1804)

Vespidae Ancistrocerus antilope (Panzer, 1798)

Antepipona orbitalis (HerrichSchöffer, 1839)

Dolichovespula (s. str.) sylvestris (Scopoli, 1763)

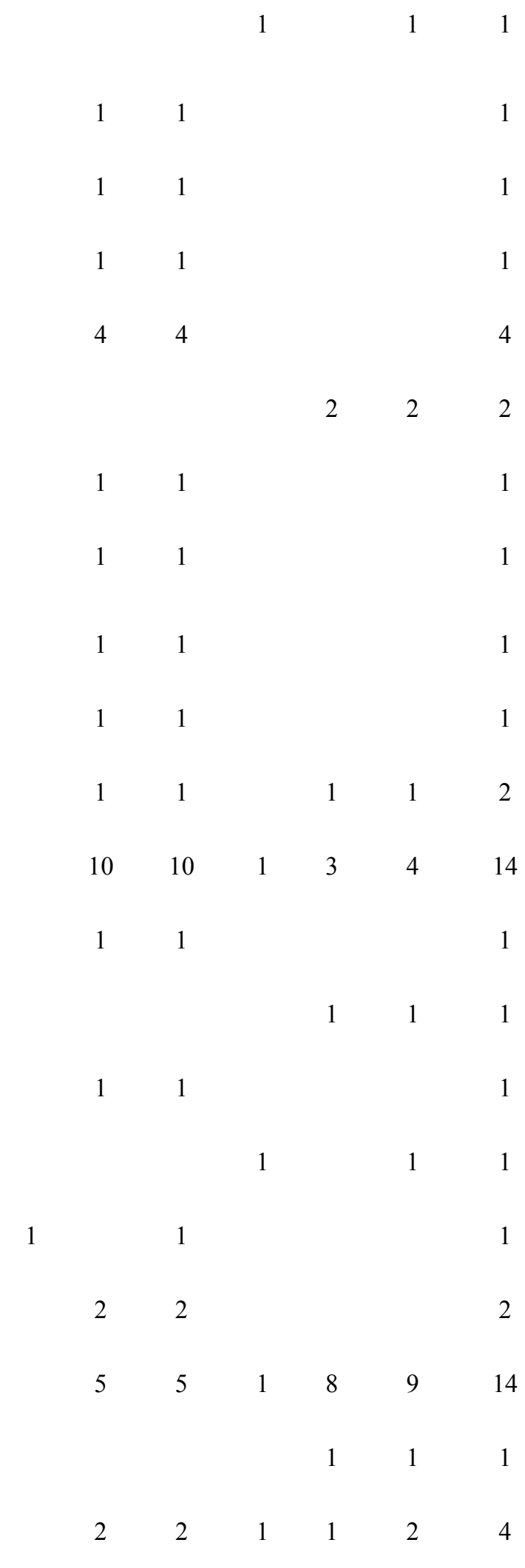

2

4

1

4 
Eumenes mongolicus F.Morawitz, 1889

Polistes (s. str.) biglumis

(Linnaeus, 1758)

Polistes (s. str.) dominulus (Christ, 1791)

Vespula (Paravespula) germanica (Fabricius, 1793)

Vespula (Paravespula) rufa (Linnaeus, 1758) $\begin{array}{lll}1 & 1 & 1\end{array}$

$3 \quad 3 \quad 3$

$\begin{array}{lllllll}2 & 2 & 1 & 4 & 5 & 7\end{array}$

$\begin{array}{llllll}1 & 1 & 1 & 4 & 5 & 6\end{array}$

$\begin{array}{llllll}4 & 4 & 1 & 5 & 6 & 10\end{array}$

252

229

481

652


Appendix 4. Management practices targeted in home garden development initiative, Issyk-kul, Kyrgyzstan.

\begin{tabular}{l} 
Management practice defined in context \\
\hline Pruning: Removal of branches from fruit trees to \\
encourage fruit set, air flow for disease prevention, \\
and light penetration for fruit development in \\
current year and for future yields
\end{tabular}

Grafting: Removing a branch or bud from a tree and introducing a branch (scion) or bud from a donor tree to refresh an older branch or replace the variety

Thinning: Removal of young fruits from fruit trees, ideally one month following full bloom, to reduce insect infested and diseased apples, to grow fewer, but larger fruits, and to preserve trees' reserves for the formation of following year's fruit buds to prevent biennial bearing

Organic fertilizers: Manure (cow, sheep, goat, horse, and poultry) is the main organic fertilizer used to maintain soil fertility

Compost: Decomposed plant material and manure that can be used as an organic fertilizer.

Biological Insect Control: The use of beneficial insects, primarily predatory wasps, or other homebrewed insect deterrents such as tobacco and garlic teas

Saplings: Planting new saplings to replace old trees or to establish new home gardens including spacing, site and planting hole preparation
Current practice in communities

Not aggressive enough resulting in shading of developing fruits, breakage of branches when in fruit, and poor intercrop performance due to shading

Grafting widespread, but with limited success due to the removal of all branches leaving only the stump (shocking to the tree and no photosynthesis) and sealing cuts and grafts with manure and clay mixtures introducing diseases

Not widespread practice due to the reluctance of growers to remove fruits, and those that did practice, performed the practice later in the growing season and not aggressively enough to realize full benefits from the following year's yield

Use is widespread but some issues were: (a) the use of fresh manure which can introduce harmful bacteria, weeds and scald vegetation and (b) over-use, which can lead to water contamination, overgrowth of foliage and underdevelopment of fruit.

Composting was not widespread. Organic matter wastes were either fed to animals or burned and ashes not returned to the garden.

Not widespread. There is a laboratory that raises predatory wasps that parasitize most fruit moth eggs, so this was the main focus of the development initiative due to their availability.

Trees in gardens were older than productive life of 7-30 years and needed to be replaced (saplings) or refreshed (grafting and pruning) 
VITA

\section{ROBIN COLLEEN DOUGHERTY CURREY}

1992-1995

1995-1999

$1997-2001$

1998-1999

$1999-2000$

2001-2002
B.S., Resource Ecology and Management

School of Natural Resources and Environment

University of Michigan

Ann Arbor, Michigan

M.S., Resource Ecology and Management

School of Natural Resources and Environment

University of Michigan

Ann Arbor, Michigan

Graduate Student Instructor, Woody Plant Biology, Wildlife

Ecology \& Psychology

University of Michigan

Ann Arbor, Michigan

Graduate Student Instructor, Ethnobotany \& Conservation Biology

University of Michigan Biological Station

University of Michigan

Pellston, Michigan

Research Assistant, Ethnoecology

School of Natural Resources and Environment

University of Michigan

Ann Arbor, Michigan

Consultant, Plant Ecology and Ethnoecology

Southwest Archaeological Consultants

Santa Fe \& Raton, New Mexico

Researcher, Plant Ecology

University of Michigan Biological Station

University of Michigan

Pellston, Michigan

Graduate Student Instructor, Human Biology

Florida International University

Miami, Florida 
2004-2005

2005-2008

2008-

AWARDS

1992-1995

1995

1999

2001-2005

2002

2002-2005

2004-2005

2005-2006

2007
Fulbright Graduate Research Fellow

Agricultural University of Kyrgyzstan

Bishkek, Kyrgyz Republic

Science Advisor

Mercy Corps and Kompanion Microfinance Group

Bishkek, Kyrgyz Republic

Deputy Country Director

Mercy Corps Kyrgyzstan

Bishkek, Kyrgyzstan
Michigan Veterans Trust Fund Fellowship

Xi Sigma Pi, National Honor Society of Forest Resource

Management, University of Michigan Chapter

Schultz Wildlife Ecology Award

Resource Ecology \& Management Faculty, University of Michigan

Presidential Enhanced Graduate Assistantship Award for Doctoral

Studies, Florida International University

Slavic Language Institute Fellowship

University of Michigan Summer Language Institute

Science to Achieve Results (STAR) Fellow

United States Environmental Protection Agency

Fulbright Graduate Research Fellow

Institute for International Education

Conservation Trust Research Grant

National Geographic Society

Director's Award: The Apple Project

Mercy Corps, Kyrgyzstan 